NATIONAL LABORATORY

MANAGED BY UT-BATTELLE

FOR THE DEPARTMENT OF ENERGY

\title{
Fukushima Daiichi - A Case Study for BWR Instrumentation and Control Systems Performance during a Severe Accident
}

\section{April 2013}

Prepared by

D. A. Clayton

W. P. Poore, III

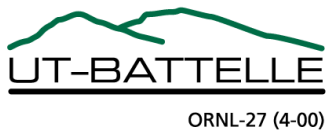




\section{DOCUMENT AVAILABILITY}

Reports produced after January 1, 1996, are generally available free via the U.S. Department of Energy (DOE) Information Bridge.

Web site http://www.osti.gov/bridge

Reports produced before January 1, 1996, may be purchased by members of the public from the following source.

National Technical Information Service

5285 Port Royal Road

Springfield, VA 22161

Telephone 703-605-6000 (1-800-553-6847)

TDD 703-487-4639

Fax 703-605-6900

E-mail info@ntis.gov

Web site http://www.ntis.gov/support/ordernowabout.htm

Reports are available to DOE employees, DOE contractors, Energy Technology Data Exchange (ETDE) representatives, and International Nuclear Information System (INIS) representatives from the following source.

Office of Scientific and Technical Information

P.O. Box 62

Oak Ridge, TN 37831

Telephone 865-576-8401

Fax 865-576-5728

E-mail reports@osti.gov

Web site http://www.osti.gov/contact.html

This report was prepared as an account of work sponsored by an agency of the United States Government. Neither the United States Government nor any agency thereof, nor any of their employees, makes any warranty, express or implied, or assumes any legal liability or responsibility for the accuracy, completeness, or usefulness of any information, apparatus, product, or process disclosed, or represents that its use would not infringe privately owned rights. Reference herein to any specific commercial product, process, or service by trade name, trademark, manufacturer, or otherwise, does not necessarily constitute or imply its endorsement, recommendation, or favoring by the United States Government or any agency thereof. The views and opinions of authors expressed herein do not necessarily state or reflect those of the United States Government or any agency thereof. 


\title{
Fukushima Daiichi - A Case Study for BWR Instrumentation and Control Systems Performance during a Severe Accident
}

\author{
D. A. Clayton \\ W. P. Poore, III \\ Oak Ridge National Laboratory
}

Date Published: April 2013

Prepared by

OAK RIDGE NATIONAL LABORATORY

Oak Ridge, Tennessee 37831-6283

managed by

UT-BATTELLE, LLC

for the

U.S. DEPARTMENT OF ENERGY

under contract DE-AC05-00OR22725 



\section{CONTENTS}

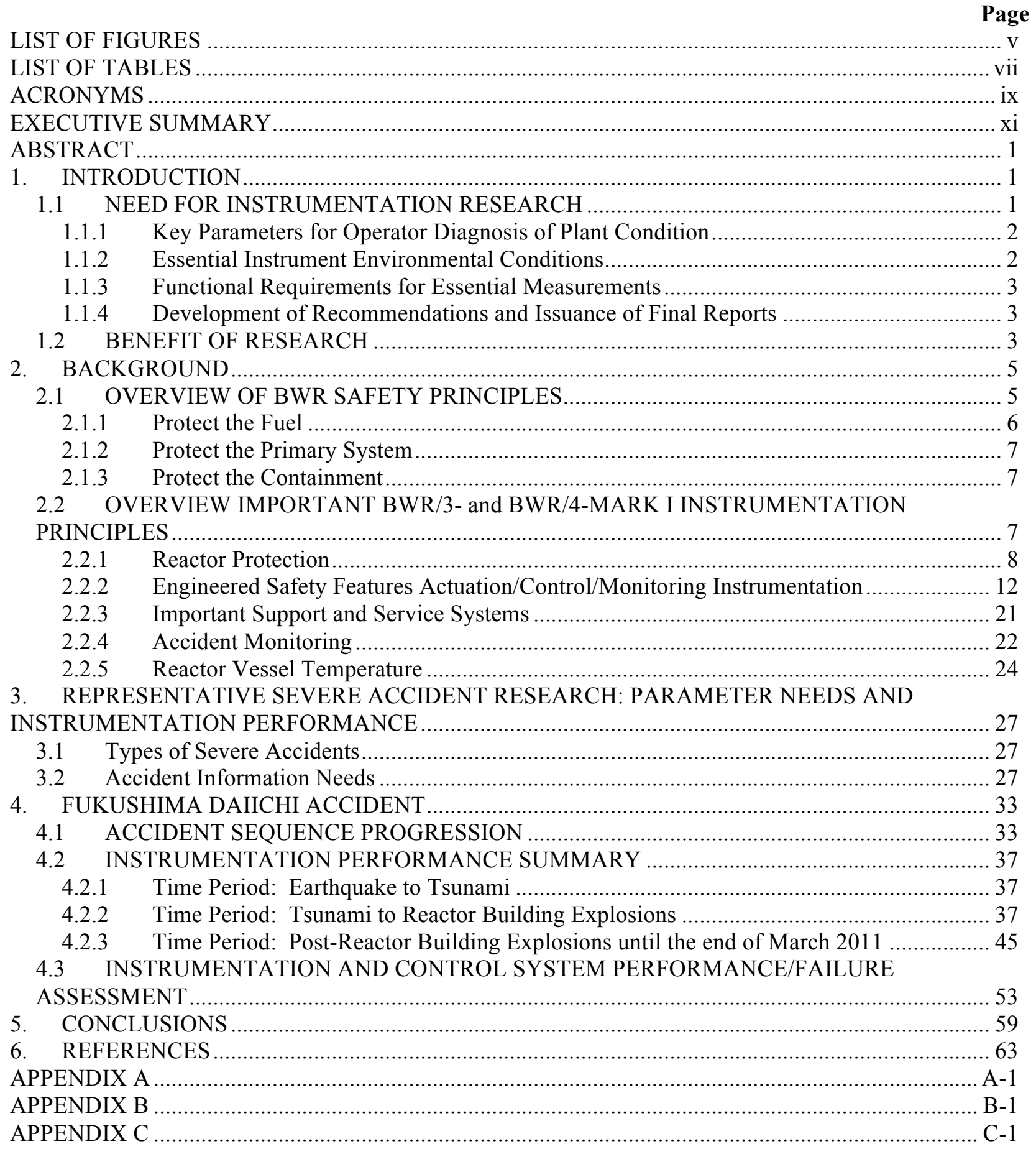





\section{LIST OF FIGURES}

Figure

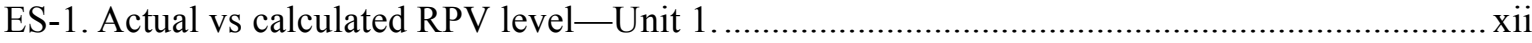

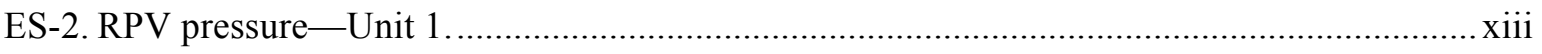

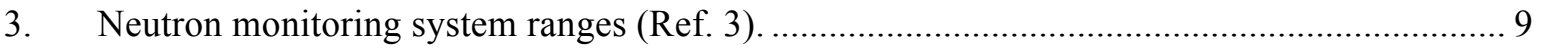

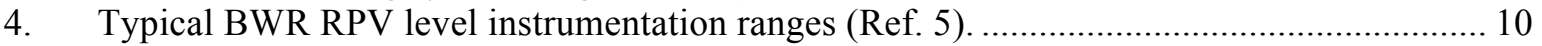

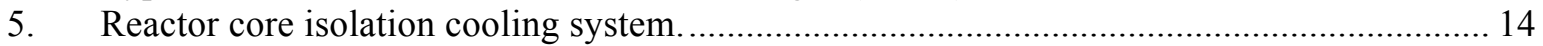

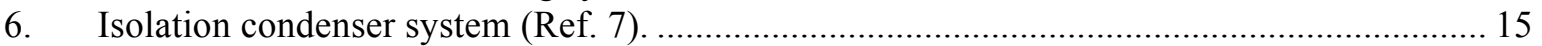

7. High pressure coolant injection system (typical) (Ref. 8) .................................................. 16

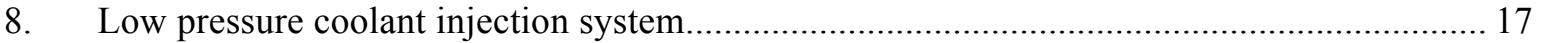

9. Mark I drywell/torus containment design......................................................................... 18

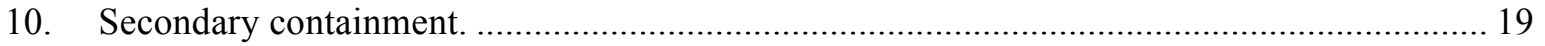

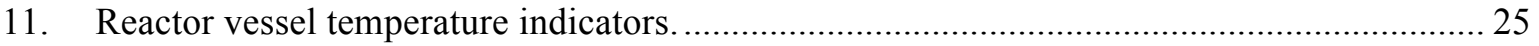

12. Fukushima Unit 1 event progression summary (TEPCO [Ref. 17], p. 179) ........................ 34

13. Fukushima Unit 2 event progression summary (TEPCO [Ref. 17], p. 212) ........................ 35

14. Fukushima Unit 3 event progression summary (TEPCO [Ref. 17], p. 237)........................ 36

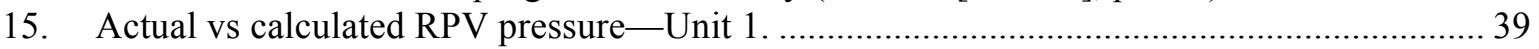

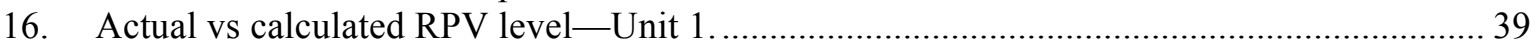

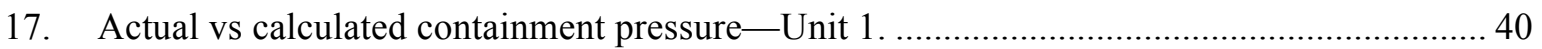

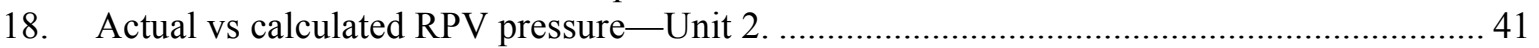

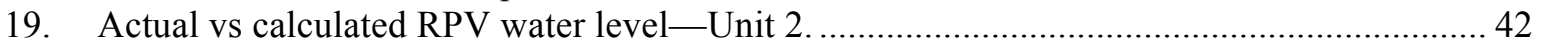

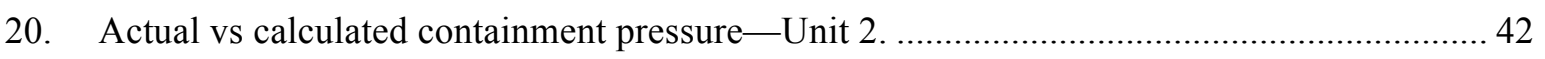

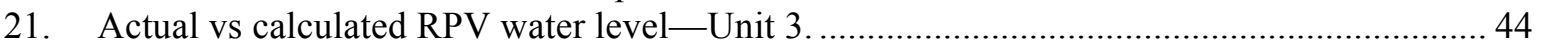

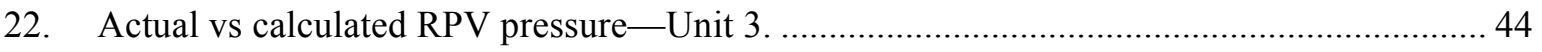

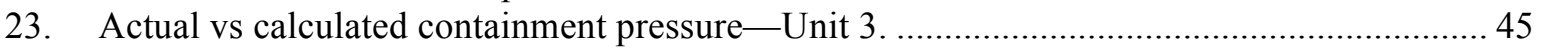

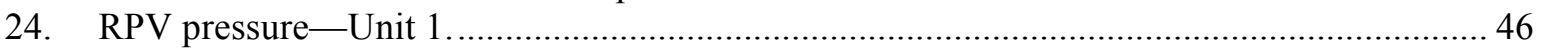

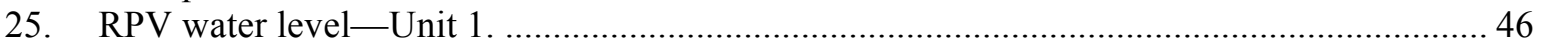

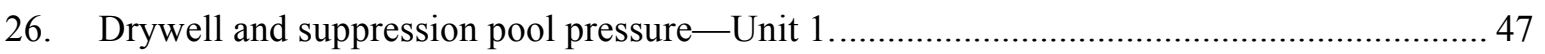

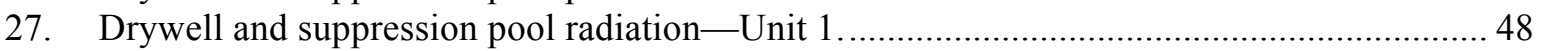

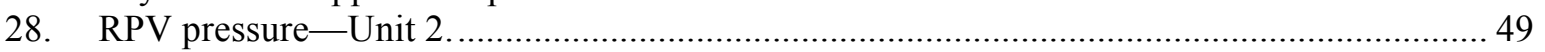

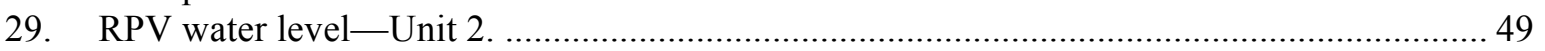

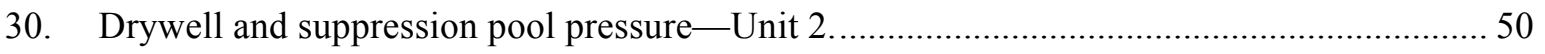

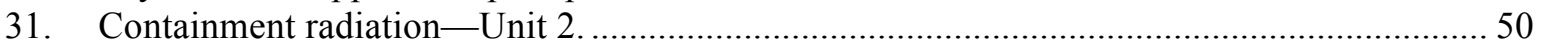

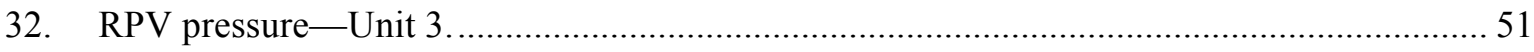

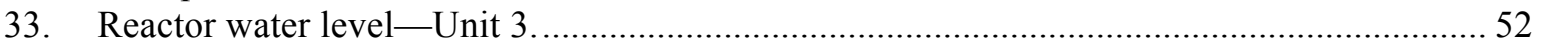

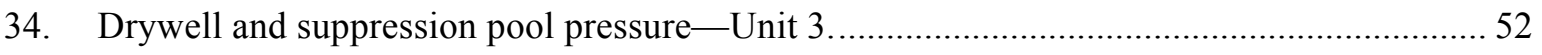

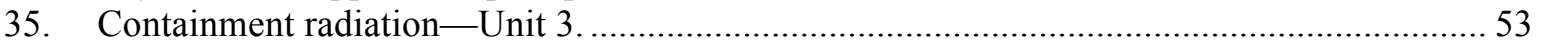





\section{LIST OF TABLES}

Table

Page

Table ES-1. Summary of apparent deficiencies for key parameters ...................................................... xiii

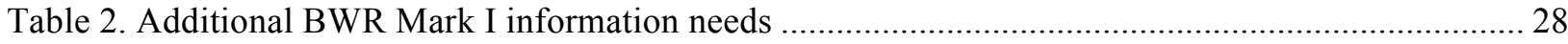

Table 3. Summary of apparent deficiencies for key parameters ............................................................ 54

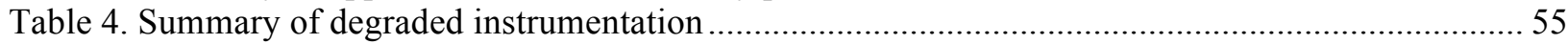

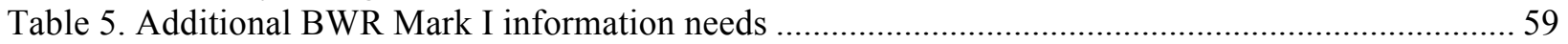

Table 6. Summary of apparent deficiencies for key parameters ........................................................... 60 



\section{ACRONYMS}

$\begin{array}{ll}\text { ADS } & \text { automatic depressurization system } \\ \text { AOO } & \text { abnormal operating occurrence } \\ \text { APRM } & \text { average power range monitor } \\ \text { ATWS } & \text { anticipated transient without scram } \\ \text { BDBA } & \text { beyond design basis accident } \\ \text { BWR } & \text { boiling water reactor } \\ \text { DBA } & \text { design basis accident } \\ \text { DOE } & \text { U.S. Department of Energy } \\ \text { ECCS } & \text { emergency core cooling system } \\ \text { EDG } & \text { emergency diesel generator } \\ \text { ENSREG } & \text { European Nuclear Safety Regulators Group } \\ \text { EOP } & \text { emergency operating procedure } \\ \text { ESF } & \text { engineered safety feature } \\ \text { FLEX } & \text { industry flexible coping capability } \\ \text { HPCI } & \text { high pressure coolant injection } \\ \text { I\&C } & \text { instrumentation and control } \\ \text { INL } & \text { Idaho National Laboratory } \\ \text { INPO } & \text { Institute for Nuclear Power Operations } \\ \text { IRM } & \text { intermediate range monitor } \\ \text { LDHR } & \text { loss of decay heat removal } \\ \text { LOCA } & \text { loss-of-cooling accident } \\ \text { LPCI } & \text { low pressure coolant injection } \\ \text { LPRM } & \text { local power range monitor } \\ \text { LWR } & \text { light water reactor } \\ \text { NRC } & \text { U.S. Nuclear Regulatory Commission } \\ \text { NTTF } & \text { NRC Near-Term Task Force } \\ \text { ORNL } & \text { Oak Ridge National Laboratory } \\ \text { PCIS } & \text { primary containment isolation system } \\ \text { PWR } & \text { Pressurized water reactor } \\ \text { RBM } & \text { rod block monitor } \\ \text { RCIC } & \text { reactor core isolation cooling } \\ \text { RG } & \text { U.S. Nuclear Regulatory Commission Regulatory Guide } \\ \text { RHR } & \text { residual heat removal } \\ \text { RPV } & \text { reactor pressure vessel } \\ \text { SBGTS } & \text { standby gas treatment system } \\ \text { SBO } & \text { station blackout } \\ \text { SLC } & \text { standby liquid control } \\ \text { SOARCA } & \text { State-of-the-Art Reactor Consequence Analysis } \\ \text { SRM } & \text { source range monitor } \\ \text { TAF } & \text { top of active fuel } \\ \text { TEPCO } & \text { Tokyo Electric Power Company } \\ \text { TMI } & \text { Three Mile Island } \\ & \end{array}$





\section{EXECUTIVE SUMMARY}

This report provides an assessment of the performance of various instrumentation and control (I\&C) and monitoring systems during and after the Fukushima accident. Like at the Three Mile Island Unit 2 (TMI-2) accident in 1979, operator responses were challenged when information on key parameters was lost, erroneous, or misleading. While progress in these areas has been made since TMI-2, the accident at Fukushima suggests there is potential for further improvement. The objective of this research is to help ensure that plant operators and emergency responders have confident, accurate, and timely knowledge of plant conditions as they implement emergency operating procedures (EOPs) guiding them through severe accidents.

I\&C systems monitor achievement of light water reactor safety principles in which the protection of the reactor fuel, reactor coolant system, and reactor containment is accomplished. This report provides an overview of the safety principles; notes parameters associated with the boiling water reactor $(\mathrm{BWR}) / 3$ and $\mathrm{BWR} / 4$ important protection, actuation, and monitoring systems as they relate to the achievement of these principles; presents data from past research on likely instrumentation performance during severe accidents; and assesses performance of the key I\&C and monitoring systems associated with the Fukushima Daiichi accident. Lessons learned or potential improvements associated with the performance of these systems in the context of severe accidents are made.

As background information, an overview of key BWR/3- and BWR/4-Mark I reactor protection, engineered safety features actuation, and accident monitoring is provided, as well as a brief description of plant safety systems used to prevent or mitigate reactor accidents. The background information will provide context in the brief discussion of previous research that has been conducted on BWR severe accidents and in the discussion of the accident sequences that led to core damage at Fukushima Daiichi Units 1-3.

The progression of the accident sequences at Fukushima Daiichi Units 1-3 occurred very much as predicted in prior severe accident research conducted in the U.S. and internationally, given the complete station blackout when the tsunami generated by one of the most powerful earthquakes ever recorded rolled onshore.

Severe accident research noted the importance of instrumentation, control, and monitoring systems and their dependence on dc electrical power systems. Research in the early 1990s found that approximately 20 information needs to help cope with severe accidents were not directly provided. Vulnerabilities of plant monitoring systems to various severe accidents were reviewed. Some responses were made: For example, at Fukushima Units 2, 4, and 6, air-cooled diesel generators were added. These provided redundancy and diversity to emergency power sources.

Offsite power supplies to the Fukushima Daiichi power station were lost as a result of the earthquake. About 40 minutes later, a series of tsunami waves $30 \mathrm{ft}$ higher than designed for flooded the site, failing the operating emergency onsite diesel generators and, critically, batteries that provide emergency backup power supplies for plant monitoring and control equipment and the power distribution panels necessary for the plants' safety-related equipment. The diverse emergency aircooled diesel generators at Units 2 and 4 themselves were apparently operable but were not able to be used to power plant loads because of the flooded electrical rooms. Lighting and communications equipment were also lost. These initiators, beyond the design bases of the plants, precipitated core damage, resulting in generation of explosive hydrogen gases, pressure releases to and from reactor containments, and subsequent explosions that severely damaged reactor secondary containment buildings and greatly challenged efforts to prevent further damage and contain additional radioactive releases. 
Instrumentation and monitoring equipment necessary to guide accident management activities was lost. Operators were dispatched to hazardous areas of the plants' reactor buildings to obtain instrument readings and to control systems because of lack of power to main control rooms. Even as power was restored, apparent deficiencies in instrumentation performance, such as shown in Fig. ES1 , were noted. In this figure, different reactor water level readings in redundant instruments A-B are shown in the March 12 timeframe. For several days after, there were no instrument A readings. Collectively, lack of instrument readings or uncertainty in the accuracy or timeliness of readings, as reflected in cautions from Japanese staff, can hinder accident response.

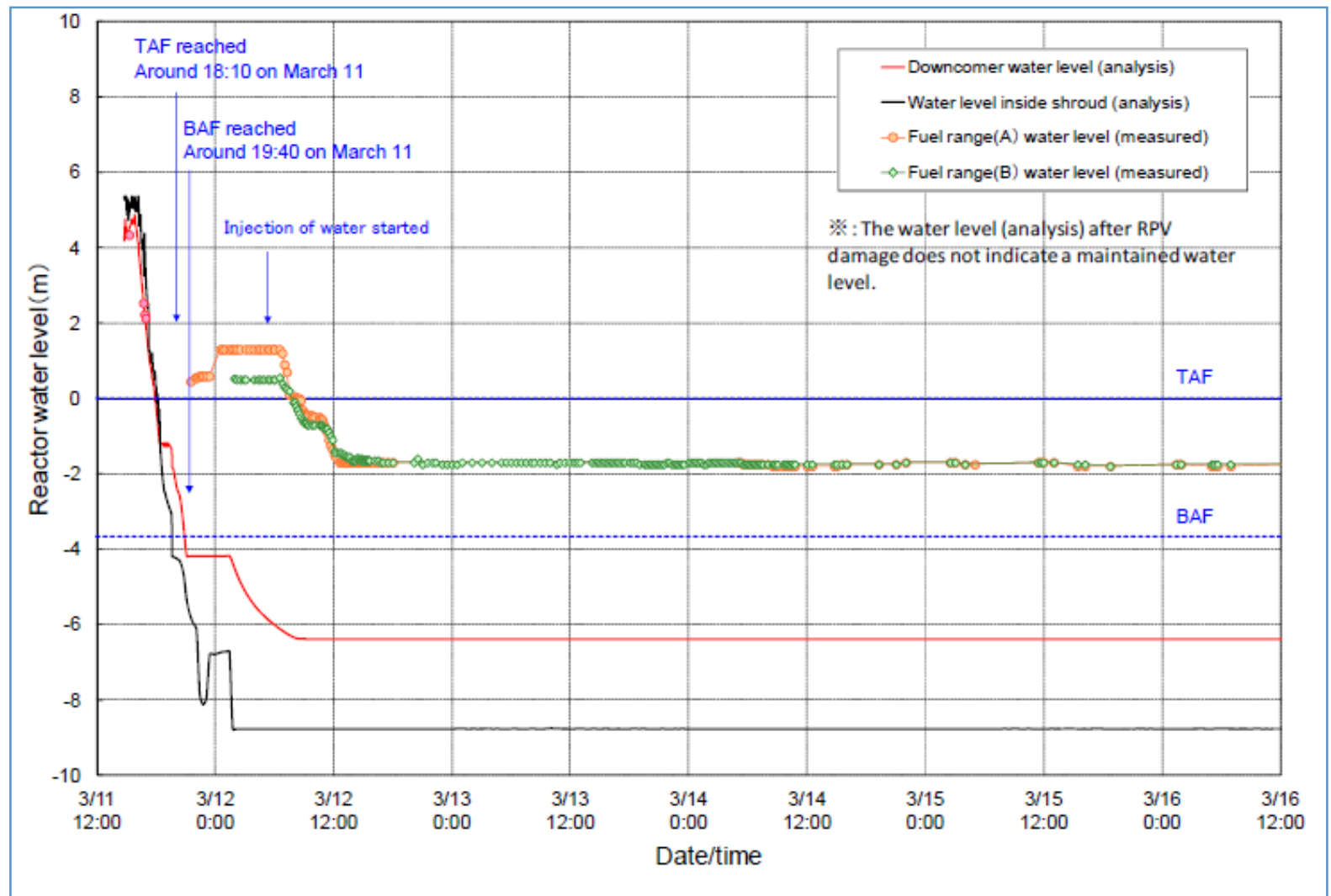

Fig. ES-1. Actual vs. calculated RPV level-Unit 1.

Figure ES-2 shows reactor pressure readings for two redundant instruments, A-B. Pressure readings are missing initially for instrument $\mathrm{A}$. Then, readings for the two instruments show opposite trends before readings converge between March 16 and 26. The readings diverge starting on March 26. Explanations for the difference in readings for the two instruments were not provided. As they occur, readings like this generate considerable attention as operators now try to discern whether significant plant changes are taking place and try to gather complementary data to verify one reading or the other.

The evaluation of the sequence of events of the accident at Fukushima Daiichi Units 1-3 focused on efforts to understand and mitigate the accident. Instrumentation issues discussed were for key parameters such as reactor vessel level and pressure, drywell pressure, and suppression pool pressure. Problems or apparent deficiencies with instruments for these parameters are summarized in Table ES-1. 


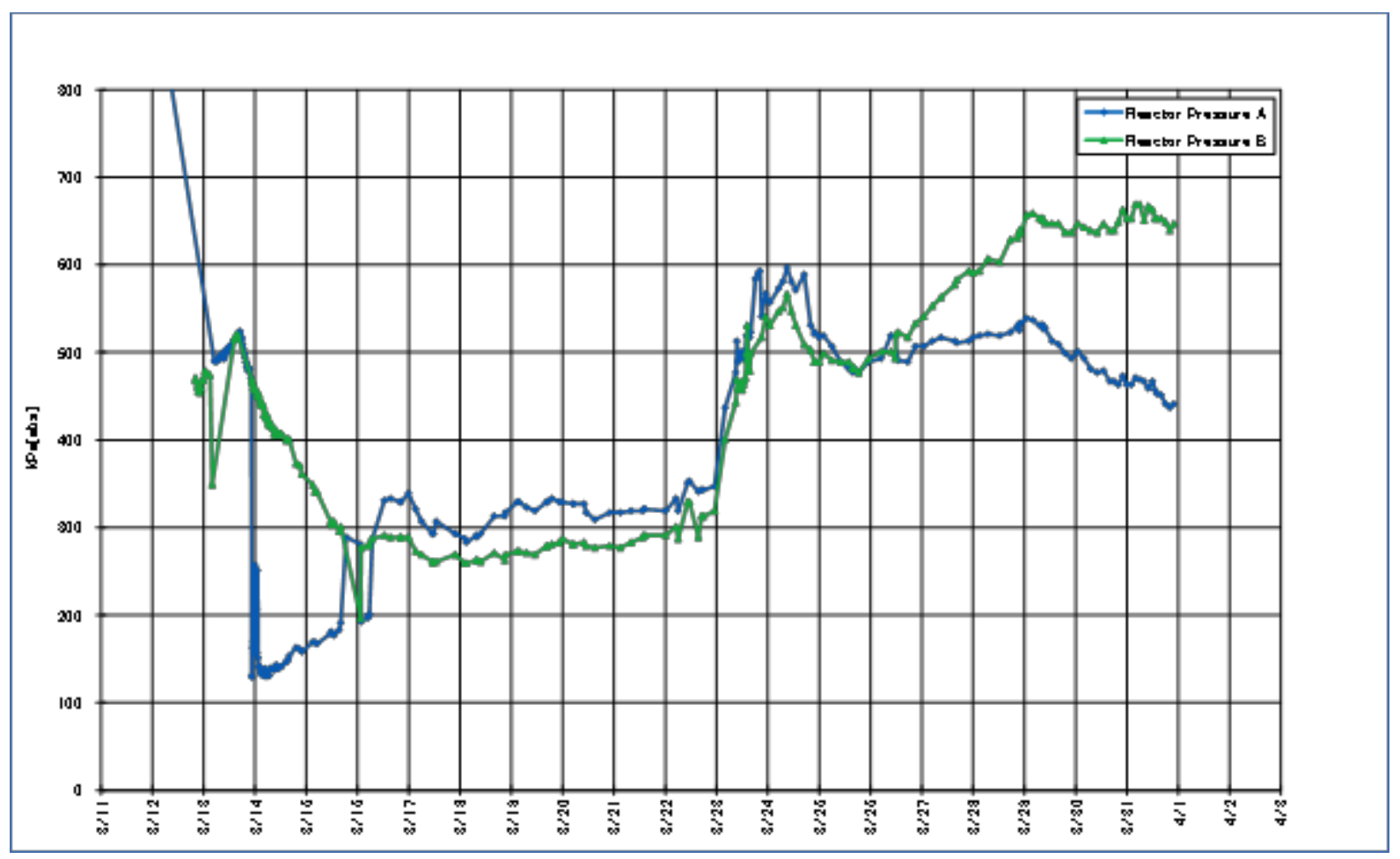

Fig. ES-2. RPV pressure-Unit 1.

Table ES-1. Summary of apparent deficiencies for key parameters

\begin{tabular}{|l|l|}
\hline \multicolumn{1}{|c|}{ Measured parameters } & \multicolumn{1}{c|}{ Apparent deficiencies } \\
\hline Reactor vessel pressure & $\begin{array}{l}\text { Missing data, differences between instruments of about 0.5 MPa, } \\
\text { divergent data }\end{array}$ \\
\hline $\begin{array}{l}\text { Reactor vessel water } \\
\text { level }\end{array}$ & $\begin{array}{l}\text { Differences between instruments of about 0.8 m, missing data, calibration } \\
\text { errors due to reference columns with low/no water level, diverging data }\end{array}$ \\
\hline Containment pressure & Missing data \\
\hline Containment radiation & Data spikes, missing data \\
\hline Reactor vessel pressure & Erroneous indication attributed to battery degradation, missing data \\
\hline $\begin{array}{l}\text { Reactor vessel water } \\
\text { level }\end{array}$ & $\begin{array}{l}\text { Incorrect data due to undetected calibration problem, missing data, } \\
\text { differences between instruments }\end{array}$ \\
\hline Containment pressure & Differences between instruments, erratic or missing data \\
\hline Containment radiation & $\begin{array}{l}\text { Data spikes, missing data, apparently low suppression pool radiation } \\
\text { values }\end{array}$ \\
\hline \multicolumn{1}{|c|}{ Unit 3} & \\
\hline Reactor vessel pressure & Differences between instruments, \\
\hline $\begin{array}{l}\text { Reactor vessel water } \\
\text { level }\end{array}$ & $\begin{array}{l}\text { Missing data possibly due to depleted batteries, differences between } \\
\text { instruments, divergent data }\end{array}$ \\
\hline Containment pressure & Anomalous readings, missing data \\
\hline Containment radiation & Apparently low suppression pool radiation values \\
\hline
\end{tabular}


Although loss of instrument power was the initial reason for the loss of instrument capability, the harsh environmental conditions faced by the instrumentation almost certainly exceeded equipment environmental qualifications. Since detailed information on the performance, actual accident operating environments (e.g., pressures, temperature, radiation, humidity), and failure analysis were not a priority during the initial accident assessments for key instruments and measured parameters nor for the spectrum of other important measurement or accident monitoring instrumentation, these important factors were not thoroughly examined in this report. However, a speculative assessment of the availability of these other instruments is provided in Section 4.3.

Additional research is warranted to investigate the root causes and specific failure modes of the plants' instrumentation. In the near term, four additional tasks are envisioned as being necessary to complete the evaluation of accident-tolerant instrumentation under the severe accident conditions experienced at Fukushima Daiichi Units 1-3. The tasks are:

- Task 1: Determine key parameters needed to diagnose plant conditions

- Task 2: Determine the harsh environmental conditions faced by the instruments measuring these parameters

- Task 3: Develop instrumentation functional requirements

- Task 4: Make recommendations for research and development to provide the monitoring capabilities in the functional requirements 


\begin{abstract}
This document summarizes available information regarding instrumentation performance during the accident at Fukushima Daiichi power station in Japan. Specifically, the report identifies key parameters used for subsequent boiling water reactor (BWR)/3 with a Mark I containment (BWR/3Mark I) and BWR/4-Mark I accident evaluations and what sensors are available to monitor these parameters, either directly or indirectly, within the reactor vessel, drywell, suppression pool, and reactor building. For each sensor, a description is provided regarding the measured data, conclusions related to the sensor survivability, and the basis for conclusions about its survivability. Analyses of assessments of the Fukushima Daiichi accident were performed to assess the performance of key instrumentation during this event. The analyses included observation by Japanese experts regarding instrumentation performance, alternative measurement capabilities, and comparisons of instrument readings.
\end{abstract}

\title{
1. INTRODUCTION
}

The accidents at the Three Mile Island Unit 2 (TMI-2) and Fukushima Daiichi Units 1-3 nuclear power plants demonstrate the critical importance of accurate, relevant, and timely information on the status of reactor systems during a severe accident. The TMI-2 accident highlighted the critical importance of understanding and focusing on the key elements of system status information in an environment where operators - even with emergency operating procedures (EOPs) to guide prompt, logical decision making to place the plant in a safe condition-were challenged when information on key parameters was lost, erroneous, or misleading. While progress in these areas has been made since TMI-2, the accident at Fukushima suggests that there is potential for further improvement.

Recognizing the significant technical and economic challenges associated with modification of plant instrumentation, it is important to focus on the most essential data needs which can be factored into better EOP guidance and lead to enhanced plant safety.

This report provides an assessment of the performance of various instrumentation and control (I\&C) and monitoring systems during and for about two weeks after the Fukushima accident. These systems measure achievement of light water reactor (LWR) safety principles in which the protection of the reactor fuel, reactor coolant system, and reactor containment is accomplished. This report provides an overview of the safety principles; notes parameters associated with the BWR/3 and BWR/4 reactor protection system, engineered safety features (ESF) actuation system, and accident monitoring system as they relate to the achievement of these principles; presents data from past research on likely instrumentation performance during severe accidents; and assesses performance of the key I\&C and monitoring systems associated with the Fukushima Daiichi accident. Lessons learned or potential improvements associated with I\&C and monitoring systems performance in the context of severe accidents are discussed.

\subsection{NEED FOR INSTRUMENTATION RESEARCH}

A comprehensive evaluation of instrumentation performance is needed so that the most information can be gleaned from the accidents at TMI-2 and Fukushima Daiichi Units 1-3. This comprehensive evaluation should include a careful examination of available data, an analysis relying on basic engineering principles, an analysis of operator information, laboratory evaluations, comparisons with accident simulations results and large integrated tests, and post-accident inspection. 
As seen with the analysis of the TMI-2 event, many insights to what occurred were not available until at least a decade after the event; and gaining these insights required an integrated process that included post-accident videos, examinations of samples of core debris and vessel structures, instrumentation data, calculations with "best-estimate" severe accident analysis tools, separate effects laboratory tests, and in some cases, data from large integral tests. Just as there was insufficient data available from any single source to develop a complete understanding about the TMI- 2 accident, it is reasonable to expect a similar analysis to interpret and integrate information will be needed for the accidents at Fukushima Daiichi.

Although this report evaluates the effects of sensor failure or degradation at Fukushima Daiichi Units 1-3 through a review of literature and other information sources based on the event sequences, additional research is warranted to investigate root causes and specific failure modes. In the near term, four additional tasks are envisioned as being necessary to complete the evaluation of accident tolerant instrumentation.

\subsubsection{Key Parameters for Operator Diagnosis of Plant Condition}

The first task following this report should determine and document the key parameters for operator diagnosis of plant condition. Through a review of literature and other relevant knowledge bases (e.g., plant-specific and owner-group - generic EOPs, severe accident management guidelines a list of essential plant parameters most essential for operators to diagnose the state of the plant and prevent or mitigate severe accidents needs to be developed. This is essentially a function needs analysis intended to be a first principles needs analysis and not limited to looking at parameters that are currently monitored.

\subsubsection{Essential Instrument Environmental Conditions}

The second task following this report should determine the environmental conditions of essential instrumentation during a severe accident. The U.S. Nuclear Regulatory Commission (NRC) recently completed the State of the Art Reactor Consequences Analysis (SOARCA) (Ref. 1) project to develop best estimates of the offsite radiological health consequences for potential severe reactor accidents. SOARCA analyzed the potential consequences of severe accidents at the Surry Power Station and the Peach Bottom Atomic Power Station. Because this SOARCA information represents the most complete, up-to-date evaluations of conditions that may occur at U. S. nuclear power plants for a range of severe accidents, the SOARCA plants should be selected as pilot plants for this task. Specifically, this task will review plant-specific calculation results for the SOARCA Peach Bottom boiling water reactor (BWR) and the Surry pressurized water reactor (PWR) to quantify, to the extent possible, the environment (e.g., pressures, temperatures, integrated radiation dose, seismic fragility) that essential instruments would have to survive to remain functional during risk-dominant severe accidents for two pilot plants (one BWR and one PWR). It should also be noted that the source of instrument failure may not be the sensor itself; for example, the wiring which transmits the instrument signal may fail first. Therefore, for this task the "instrument" should include all associated components (e.g., wiring, power supply) necessary for correct operation. The impact of reestablishing power from alternate power sources that are currently implemented as part of the B.5.b measures implemented at U. S. plants by the NRC and industry after the Fukushima Daiichi events (e.g., NRC Near-Term Task Force [NTTF] activities, U.S. nuclear industry diverse and flexible coping capability (FLEX) measures) should also be considered. 


\subsubsection{Functional Requirements for Essential Measurements}

The third task following this report should examine the functional requirements for essential measurements. Based on the results of the above tasks, a determination is needed of what monitoring capabilities should be further developed. These requirements should be expressed as functional requirement (e.g., the ability to measure water level to within plus or minus 5 in. during pressures up to the reactor vessel maximum design pressure) rather than as sensor-specific recommendation.

\subsubsection{Development of Recommendations and Issuance of Final Reports}

Based on the tasks discussed above, the fourth task should provide specific recommendations on plant instrumentation research and development to provide the monitoring capabilities identified in the functional requirements. As part of this task, input and participation will be solicited from interested stakeholders from utilities, plant designers, Japanese organizations, the NRC, and the instrumentation industry.

\subsection{BENEFIT OF RESEARCH}

The benefit of this research is to help ensure that plant operators and emergency responders have confident, accurate, and timely knowledge of plant conditions as they implement EOPs guiding them through severe accidents to implement the most effective actions to prevent, mitigate, or contain fuel damage, and minimize public exposure to radionuclide releases. 



\section{BACKGROUND}

The nuclear accidents at the Japanese Fukushima reactors Units 1-4 are the worst tied to commercial nuclear power plants since the catastrophic Chernobyl accident in 1986. After the plant apparently survived one of the highest magnitude earthquakes on record, which caused a loss of all offsite ac electrical power, a series of devastating tsunami waves far higher than designed for inundated the plant site and caused a loss of all emergency onsite ac and dc electrical power. This caused a complete, long-term station blackout (SBO). Air-cooled diesel generators at Units 2 and 4 survived the flood; however, they were rendered useless because of flooded power distribution panels.

A long-term SBO, including the dc power system, is one of the most challenging events for a conventional LWR. Active safety systems designed to flood and cool a nuclear reactor core were lost. I\&C systems designed to monitor reactor core conditions, containment conditions, and offsite radiation levels were lost. Without knowledge of plant conditions and without the ability to control plant equipment, the ability to implement emergency operating procedures for severe accident management was almost completely lost. The ability to operate and manage the Fukushima plants from darkened control rooms and communicate with operators throughout the plants and with technical experts offsite was lost, degraded, or delayed.

Even as power was restored, instrumentation to indicate key plant parameters, monitor changing conditions, and control remaining functional equipment was inoperable, degraded, or inaccurate; and there was no effective means for repair, maintenance, or calibration. This section briefly describes the reactor safety principles and the roles for reactor protection, ESF actuation, and accident monitoring I\&C systems.

\subsection{OVERVIEW OF BWR SAFETY PRINCIPLES}

Simply stated, BWRs share safety principles with all commercial LWR power plants. These safety principles are to protect the public from harm associated with plant accidents by developing robust designs, with margin, that accommodate normal foreseen operating conditions, less frequent but more serious challenges, and even less frequent but severe challenges. To protect against these challenges, a design philosophy of diversity, redundancy, and defense-in-depth ensures that reactor fuel integrity is maintained in the case of single and multiple failures in one or more safety systems for the spectrum of normal, expected events to DBAs. Multiple and diverse safety systems are designed to protect the fuel and the reactor coolant system integrity surrounding the fuel, both to protect the fuel and provide a boundary to enclose radioactive contamination in the event of fuel failure. Containment structures and systems provide an additional boundary to contain radioactive contamination in the event of fuel failures and breaches of the reactor coolant system so that the contamination does not reach the environment and a pathway to the public. In summary, the principles are to protect the fuel/clad boundary, the reactor coolant system boundary, and the containment boundary.

Instrumentation systems that are important to safety also employ principles of diversity, redundancy, and defense in depth to ensure the observation and monitoring of plant parameters indicative of a sequence of events that could threaten fuel integrity lead to protective actions, such as a reactor scram and/or actuation of safety systems. Additionally, should there be an accident, instrumentation systems are provided to monitor, measure, and inform plant staff and emergency responders so that consequences to the plant, environment, plant personnel, and the public can be minimized.

The accident at Fukushima highlighted deficiencies in the implementation of these safety principles for the nuclear units at that site following the severe earthquake centered offshore and the resulting series of tsunami waves that followed shortly after - waves much higher than designed for at this site. 
Many Japanese and international reviews of the accidents and their causes have taken place and more are underway. They have been extensively documented from a number of perspectives and are widely available. This report looks specifically at the performance of plant instrumentation during and following the accidents to identify opportunities to better design and utilize instrumentation systems under severe, or beyond-design-basis, conditions to protect the fuel, protect reactor coolant system integrity, preserve containment functions, and help inform public safety decisions in the event radioactive contamination is released to the environment.

\subsubsection{Protect the Fuel}

Nuclear plants are operated within sets of limits designed to protect the nuclear fuel. The fuel, typically consisting of uranium oxide fuel encased in zirconium alloy cladding, performs well under design conditions; but at very high temperatures, the fuel can melt. An exothermic chemical reaction with the zirconium cladding and water/steam can then occur; such a reaction results in generation of heat, further raising fuel temperature, plus the production of hydrogen gas which could escape into plant buildings and structures and explode under the worst conditions. Plant designers develop a set of reactor operating limits under which fuel damage cannot occur. Plant instrumentation monitors numerous reactor core and balance-of-plant parameters to identify challenges to the operating limits and initiate protective or corrective responses. Protective responses include a reactor scram to rapidly shut down the reactor. This decreases heat generation in the fuel by about $90 \%$ immediately. The remaining $10 \%$ of the heat generated, approximately $300 \mathrm{MW}$ (thermal) initially for a large plant, decays away exponentially, more quickly at first and then at a more constant rate over days and weeks. This removal of this decay heat is usually the most challenging factor in safely maintaining a reactor in a shutdown condition. Without systems to remove this decay heat, fuel damage can occur quickly.

Designers provide systems to respond to challenges. Some are anticipated to occur frequently over the design lifetime of the plant. Other challenges, termed abnormal operating occurrences (AOOs), are expected to occur less frequently, maybe once or a few times over the life of the plant. More serious challenges, termed design basis accidents (DBAs), may not be expected to occur over the lifetime of the plant but could occur at a frequency high enough (e.g., less than $10^{-4}$ to $10^{-5}$ per year of reactor operation) and with consequences serious enough that they must be considered by the plant designers. Designers in the U.S. must ensure that their reactor designs are designed and built to withstand normal operating transients, AOOs, and DBAs; that is, the fuel performance, reactor coolant system integrity, and containment performance would prevent radiological doses to the public from exceeding certain values if one of these events were to occur. Another class of accidents - severe accidents, or beyond design basis accidents (BDBAs) - could have serious consequences, but the expected frequency of occurrence is below a low threshold (e.g., less than $10^{-5}$ to $10^{-6}$ per year of reactor operation for typical current plants; less than $10^{-6}$ to $10^{-7}$ per year for more advanced designs). BDBAs are not fully considered in the design process because they are judged to be too unlikely. Different countries may use different values, but the implementation of the design requirements is similar.

A loss of offsite ac electrical power is a DBA; it is expected and planned for. Onsite emergency ac electrical power will be provided by emergency diesel generators in the event of a loss of offsite power. Fuel for the diesel generators is stored onsite to last for a minimum of 7 days (Ref. 2) following a loss of offsite power and a DBA before delivery of additional fuel would be required. However, an event or sequence of events that would lead to a complete SBO-loss of offsite power, loss of emergency onsite emergency ac electrical power, and loss of onsite emergency dc electrical power (typically used to power monitoring and control systems and enable valve actions to bring the plant to a desired configuration) - is a challenging BDBA. 
The accident at Fukushima was such a BDBA event in Japan. The plant was designed to withstand an earthquake with peak ground accelerations such as those experienced and to cope with a loss of offsite power. However, plant designers did not design the plant to withstand near simultaneous tsunami waves of the magnitude that ultimately caused loss of all onsite emergency diesel generators at Units 1-6 (except for one air-cooled diesel generator at Unit 6-; Units 2 and 4 also had air-cooled emergency diesels; but, they were unavailable because of flooded power distribution panels). The designers did not design the plant to withstand the height of the tsunami waves that damaged or destroyed many plant structures, systems, and components including, safety-related ac and dc electrical power systems, cooling water systems, control room functions, and the plants' ultimate heat sinks. These led to the core damage at Units 1-3, additional structural damage at Units 1-4, loss of containment integrity and radionuclide releases from Units 1-3, and widespread environmental contamination.

\subsubsection{Protect the Primary System}

A function of the reactor coolant system is to ensure that the heat from the nuclear fuel is removed and the fuel is cooled. During power operation, nonsafety-related feedwater systems, recirculation systems, and the main steam system provide water to absorb heat from the fuel, which is boiled into steam and used to turn a turbine and power an electrical generator. Upon detection of a problem that could threaten the ability to cool the fuel, the reactor would be scrammed and, under certain conditions, valves would close to isolate the system to prevent the escape of cooling water. The isolated system typically contains a large volume that covers the fuel elements to keep them cool. However, decay heat from the fuel causes the water to heat up and boil. Steam-powered safety systems use steam-powered turbine-driven pumps to provide additional cooling water as long as enough steam is generated to power the turbines. Additional electrically powered cooling water systems are also available to recirculate cooling water through the reactor core; cool the recirculating water; and cool plant structures, buildings, or rooms. With electrical power and an ultimate heat sink to serve as a source of cooling water, the core can be maintained shutdown, cool, and safe indefinitely.

\subsubsection{Protect the Containment}

Almost all commercial power reactors in the world, with an exception being some older Soviet RBMK designs, are surrounded by a containment structure to contain radioactive contamination released in almost any type of accident. Reactor containments are designed (with margin) to withstand the pressures, temperatures, radiation exposures, and water sprays or flooding expected during design basis events. With necessary isolation systems and support systems, such as cooling systems, containment systems serve as a final barrier to the uncontrolled release of radionuclides during an accident. Containment systems and various safety systems and components located therein are designed to accommodate the harsh accident environment expected during DBAs.

The beyond DBA at Fukushima challenged the containments at Units 1-3 and, because of interconnected ventilation ducts, Unit 4. The BDBA led to radiation levels, temperatures, and pressures that exceeded equipment design limits and environmental qualifications, and allowed containment integrity of multiple units to be breached.

\subsection{OVERVIEW IMPORTANT BWR/3- and BWR/4-MARK I INSTRUMENTATION PRINCIPLES}

The basic requirement for plant instrumentation systems is to accurately measure important plant parameters on a timely basis so that there is great confidence that various operating limits across the 
spectrum of reactor core, primary systems, and balance-of-plant systems are met. Instrumentation feeds information on plant conditions to control and monitoring systems that trigger or inform corrective or protective actions. Instrumentation systems important to safety are designed with care and rigor to ensure that they perform as needed, such as those that initiate reactor protection system actions (i.e., scrams) and those that initiate ESFs (e.g., system isolations, actuations of emergency cooling systems) designed to ensure safety of the fuel, etc., during transients or accidents. (Note: this section is based on the BWR/4-Mark I design information extracted heavily from NRC training materials [Refs. 3 and 4]. Noteworthy differences from the BWR/3-Mark I design will be indicated.)

\subsubsection{Reactor Protection}

When monitored system parameters exceed predetermined limits, the reactor protection system detects conditions that threaten the fuel or primary coolant pressure boundary and initiates a rapid automatic reactor shutdown, or scram. (A manual mode is also provided.) This action prevents fuel damage and damage to the primary coolant pressure boundary and thereby limits uncontrolled release of radioactive materials. The system consists of logic circuitry, sensors, transmitters, processors, cables, and operator indicators, controls, and interface hardware. The subsections below list typical parameters used as inputs to the reactor protection system. (Please note that these parameters are typical for U.S. BWR/3 and BWR/4 reactors with Mark I containments. Instrumentation for the Japanese reactors is likely very similar.)

\subsubsection{Parameters Monitored/Instrumentation principles}

The BWR reactor protection system monitors a number of parameters and initiates a plant trip when various settings are reached. The system is characterized as a redundant, diverse, and defense-indepth system. Designers want to ensure that a scram occurs when needed but also strive to eliminate unwanted trips, their associated plant transients, and challenges to plant safety equipment. Typically, multiple sensors feed multiple channels. A scram signal requires conditions to be met for the same parameter from different sensors in multiple channels. Designers also recognize that parameter values may change depending on plant conditions. For example, changes in coolant flow rates, temperatures, and pressures may vary depending on the plant power level. Therefore, safety important systems like the reactor protection system are complicated systems. The descriptions of this system and the various parameters are meant to be illustrative rather than definitive.

\subsection{Neutron Flux}

Neutron monitoring for BWRs is done with in-core monitors. There are six major subsystems that compose the neutron monitoring system. The power ranges to which they apply are shown in Fig. 3. The system provides an important input to the reactor protection system and has value in monitoring core conditions in the event of a severe accident.

Source range monitors (SRMs) monitor neutron power from shutdown conditions to when the neutron flux overlaps the range of the intermediate range monitor (IRM) for the purpose of safely attaining criticality and initiating power ascension.

- The IRMs monitor neutron flux from the upper portion of the startup range to the lower portion of the power range. The IRMs provides scram signals.

- Local power range monitors (LPRMs) are used during power operation to provide signals proportional to local neutron flux at various in-core locations to power monitoring and control systems.

- Average power range monitors (ARPMs) are used during power operation to continually monitor core average (bulk) thermal power. APRMs initiate rod block and scram signals to prevent thermal margins from being exceeded. APRMs receive signals from LPRMs and flow 
units in the recirculating water system that are used to control reactor power.

- The rod block monitor (RBM) provides alarm and rod withdrawal blocks if core power exceeds a preset limit in relation to recirculating water flow rate to help ensure that power increases due to rod movements are maintained within desired limits.

- The traversing in-core probe provides a means of measuring thermal flux in the core in an axial direction. The probe can be inserted and removed in various channel tubes axially so that LPRMs that are in fixed positions in the core can be calibrated.

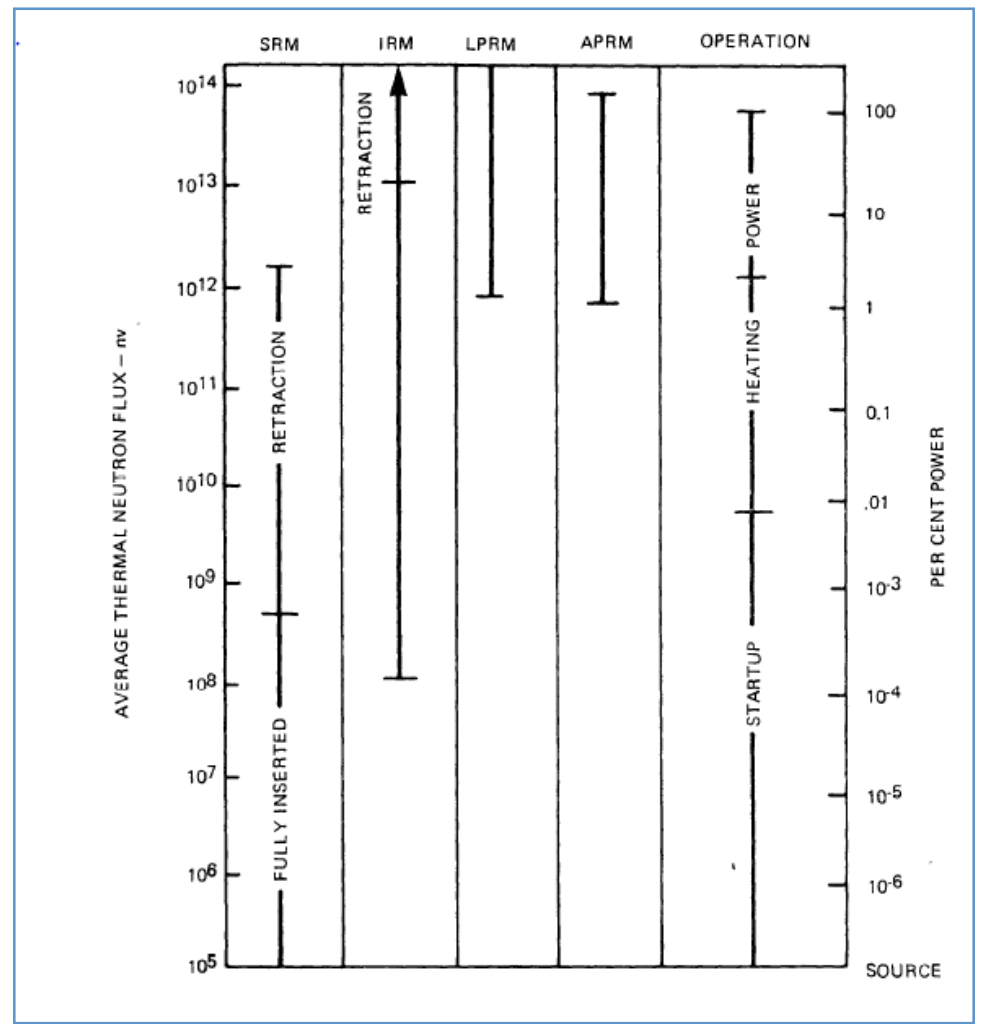

Fig. 3. Neutron monitoring system ranges (Ref. 3).

\subsection{Reactor Pressure Vessel Level}

A low water level in the reactor vessel is a reactor trip condition on the basis that reactor fuel could be subject to inadequate cooling. Reactor pressure vessel water level, measured in the reactor vessel downcomer annulus, is one of the most important parameters for the BWR. A key to keeping reactor fuel cool is to keep it covered with water. Level indications are used under normal operating conditions for feedwater control system purposes and in accident conditions to measure and initiate numerous protective and ESF functions. Numerous level indicators are provided in the reactor building at various locations and in the control room.

Fig. 4 shows multiple reactor vessel level ranges for a typical BWR. Multiple separate reactor vessel level indications are provided in the control room and continuously displayed on various panels to provide accident range readings, provide normal range readings for the feedwater control system, support low pressure coolant injection operation, and support refueling operations. Specific functions use specific level measurement ranges. Some are for a relatively narrow range, such as the feedwater control system that controls level within a narrow band. Accident range readings cover a broader band in order to stage in various accident responses as level drops below the normal range. 


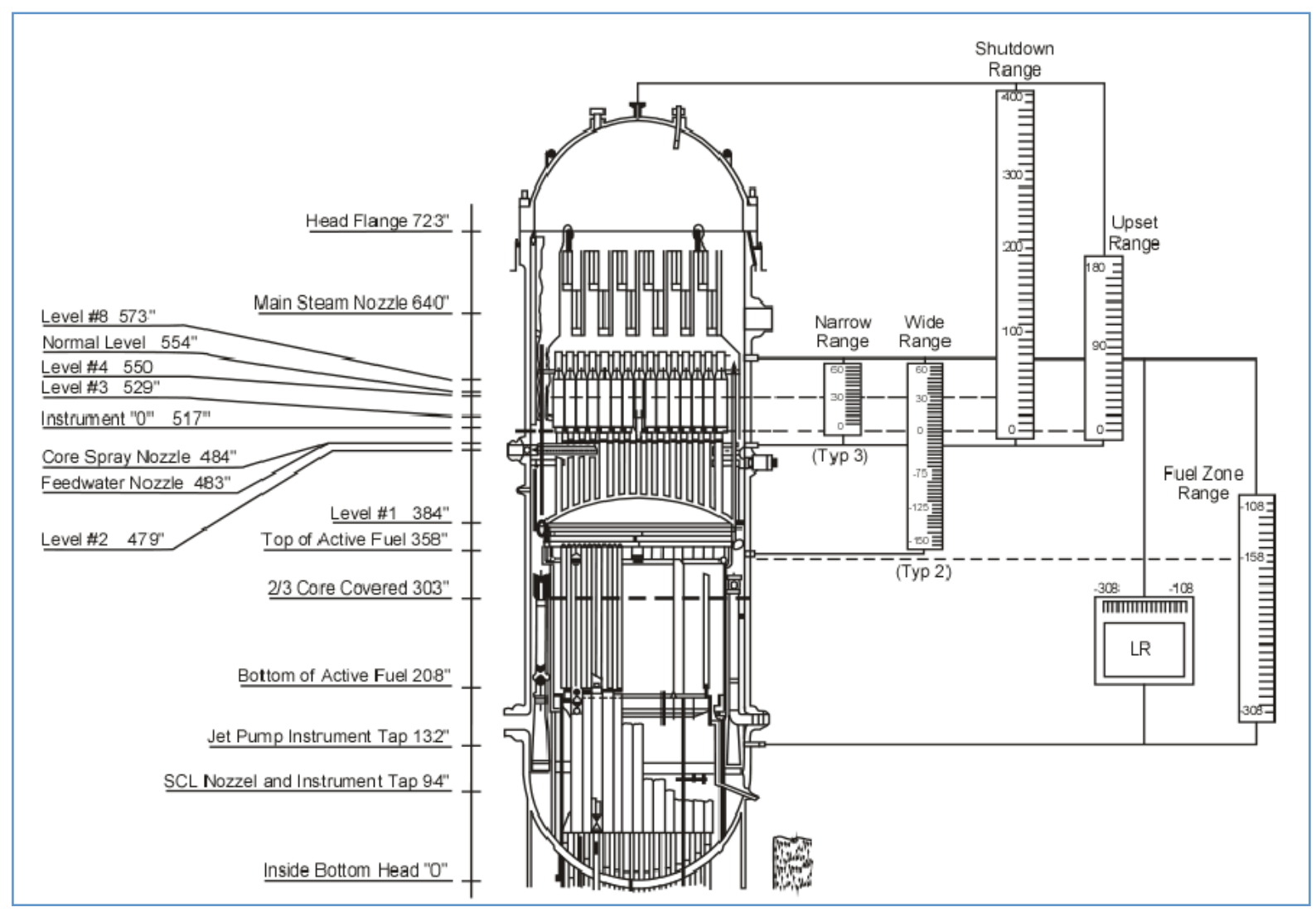

Fig. 4. Typical BWR RPV level instrumentation ranges (Ref. 5).

The low pressure injection system is controlled based on level readings across a somewhat broader range to ensure fuel rods are covered. A broad range covering to the top of the reactor vessel is used for refueling operations.

Water level is measured by means of differential pressure sensors connected to reference columns that connect to the reactor vessel at points above and below where level measurements are needed. The sensors compare the weight of water in reference columns with the height of water in the reactor vessel in the level ranges of interest and convert sensor output to correspond to a level of water corresponding to the pressure difference. Systems or equipment are often provided to ensure that reference columns are kept full. Maintenance of constant conditions in the reference columns is important to accurate level indications. If the reference level is off, then the measure reactor vessel level will also be off. Extreme environmental conditions in containment during a severe accident could cause reference column changes (e.g., high temperatures in the reference column) and lead to erroneous level indications and create a lack of confidence in the readings. It may be difficult, even with multiple sensors, to know which ones read correctly. 


\subsection{RPV High Pressure}

A high-pressure reactor trip is provided to protect against a threat of rupture of the reactor coolant pressure boundary. Increasing pressure causes steam voids to collapse and a positive reactivity insertion leading to higher fuel temperatures, potentially exceeding fuel design temperatures and system pressure limits.

Reactor vessel pressure is measured in the vessel steam space and is detected by pressure switches and indicators from instrument lines also used for water level measurements. Thus the conditions that affect level instruments affect pressure instruments. Knowledge of reactor pressure is critical in estimating the integrity of the primary coolant pressure boundary and assessing the success of low pressure coolant injection options in a severe accident.

\subsection{Turbine Stop Valve Closure}

BWRs initiate a reactor trip upon turbine stop valve closure, such as for loss of load in anticipation of a reactor vessel pressure increase and a subsequent reactor power (neutron flux) increase. This parameter is not considered of high importance or relevance in assessing instrument response during a severe accident.

\subsection{Turbine Control Valve Fast Closure}

Analogous to the turbine stop valve closure, a turbine control valve fast closure can also lead to a reactor vessel pressure increase and a subsequent reactor power (neutron flux) increase. This parameter is not considered of high importance or relevance in assessing instrument response during a severe accident.

\subsection{Main Condenser Low Vacuum}

Related to the turbine stop valve and turbine control valve closures is the main condenser low vacuum reactor protection system trip. This condition protects the condenser from potential high-pressure conditions resulting from a turbine stop valve closure and anticipates the trip signal resulting from stop valve closure. This parameter is not considered of high importance or relevance in assessing instrument response during a severe accident.

\subsection{MSIV Position}

Automatic closure of the main steam isolation valves is initiated to protect from a loss of reactor water inventory. The main steam line isolation valve position switch performance is not considered of high importance or relevance in assessing instrument response during a severe accident.

\subsection{Containment Pressure High}

A reactor trip signal on high containment pressure is provided to protect from a loss-of-reactor coolant accident. The reactor trip is to prevent fuel damage and to reduce the addition of energy to the coolant. Containment pressure indication is critical to effectively managing a severe accident.

\subsection{Main Steam Line High Radiation}

A reactor trip on high steam line radiation is provided to prevent the effects of a fuel failure from propagating to the environment.

\subsubsection{Scram Discharge Volume High Level}

The scram discharge volume receives water displaced by control rod drives piston motion during a reactor scram. A high scram discharge volume high-level reactor trip is provided to ensure that the scram discharge volume would be able to accept the water volume associated with a reactor scram. 
Without such a limit, the scram discharge volume could fill with water to a level such that it could not accommodate the water from a reactor trip; thus, a required reactor trip cold be hindered.

\subsubsection{Seismic Activity}

U.S. nuclear power plants do not typically include a direct input to the reactor protection system for seismic monitors. Foreign reactors may. However, seismic activity can cause movement of core components resulting in nuclear instrumentation sensing oscillatory flux profiles that could trigger a reactor trip (Ref. 6).

\subsubsection{Engineered Safety Features Actuation/Control/Monitoring Instrumentation}

ESF are provided in nuclear plants to mitigate the consequences of DBAs or loss-of-coolant accidents (LOCAs). The ESF actuation system monitors selected parameters and determines if the safety limits for those parameters are exceeded. Depending on which parameters are exceeded, certain safety systems are actuated in order to protect the reactor core and containment integrity. The system consists of logic circuitry, sensors, transmitters, processors, cables, and operator indicators, controls, and interface hardware. The subsections below list typical safety systems for U.S. BWR/4-Mark I reactors. Japanese reactors are very similar.

Plant instrumentation, monitoring, and control systems are used to manage operation of various plant systems, inform operators of the status of systems, and provide assurance that the complex systems of the plant are working correctly. They show that the plant is in compliance with regulations regarding release limits of radioactive materials, and toxic chemicals associated with the plant (such as for water treatment). They also can respond in a protective manner to isolate release of the various materials or isolate and protect personnel from their effects, for example, to isolate control room ventilation upon detection of a chlorine gas release. This section also includes monitoring systems that are important for ensuring that adequate data is available to inform plant operators about the status of plant conditions and guide potential accident mitigation or other responses. Instrument systems important for the performance of ESF equipment will be noted as necessary, such as control systems for coolant injection systems.

\subsubsection{Parameters Monitored/Instrumentation Principles}

The BWR ESFs actuation system monitors a number of parameters and actuates safety systems when various settings are reached. The system is characterized as a redundant, diverse, and defense-indepth system. Designers want to ensure that an actuation occurs when needed but also strive to eliminate unwanted actuations. Typically, multiple sensors feed multiple channels. An actuation signal requires conditions to be met for the same parameter from different sensors in multiple channels. Designers also recognize that parameter values may change depending on plant conditions. For example, changes in coolant flow rates, temperatures, and pressures may vary depending on the plant power level. Therefore, like the reactor protection system, the ESF actuation system is a complicated system.

Key ESF actuation parameters are associated with core cooling, maintaining containment integrity, and initiating emergency power systems. Reactor vessel low level actuates at various level indications to initiate core cooling systems and equipment: automatic depressurization system (ADS), primary containment isolation system (PCIS), high pressure coolant injection (HPCI), reactor core isolation cooling (RCIC) for the BWR/4 (isolation condenser for the BWR/3), core spray, and low-pressure coolant injection system (LPCI). As a response against a possible energy release to containment, the standby gas treatment system (SBGTS) also starts on low reactor vessel level. As a response to help ensure potential emergency core cooling system systems (ECCS) have electric power to respond as required, the emergency diesel generators (EDGs) receive a start signal on low reactor vessel level. 
The SBGTS also receives an actuation signal on high containment pressure.

Diesel generators receive an actuation signal based on low emergency bus voltage levels.

\subsubsection{Re-criticality Protection (Standby Liquid Control System)}

The standby liquid control system (SLC) provides a means of shutting the reactor down from rated power operation to cold shutdown by injecting boron in the form of sodium pentaborate into the reactor vessel. This system is used only in the unlikely event that the control rods cannot be inserted into the reactor core. If the system is needed, sodium pentaborate is pumped from its storage tank into the reactor vessel where it mixes with the reactor coolant. The boron absorbs thermal neutrons and thereby terminates the nuclear fission chain reaction.

\subsubsection{Core Flooding and Emergency Core Cooling Systems}

Core flooding systems provide or promote core cooling by injecting cold water into the reactor vessel and core or to depressurize the reactor to help remove heat and lower system pressure so that highcapacity low-pressure injection systems can function.

\subsection{Reactor Core Isolation Cooling (BWR/3)}

The RCIC system shown in Fig. 5 provides high-pressure cooling water flow ( $\sim 500-600$ gpm) to the reactor vessel following a reactor shutdown and isolation to prevent damage to the reactor core. The reactor isolation stops the normal flow of feedwater. The RCIC system uses reactor steam to power a turbine-driven pump to supply cold water preferentially from the condensate storage tank to the reactor vessel through the feedwater piping to maintain an acceptable vessel water level. The steam discharges to the suppression pool. The system is typically used to cool the reactor fuel and lower vessel pressure to a point at which shutdown cooling water systems can be used.

The I\&C system on the RCIC system manages system operation by monitoring system pressure, turbine speed, system flow, control and isolation valve positions, etc. Failure of the I\&C system typically results in loss of the system. Because the system is turbine driven, it does not require offsite or onsite electrical power as long as battery-based vital ac electrical power is available to power system I\&C equipment and valve positioning. 


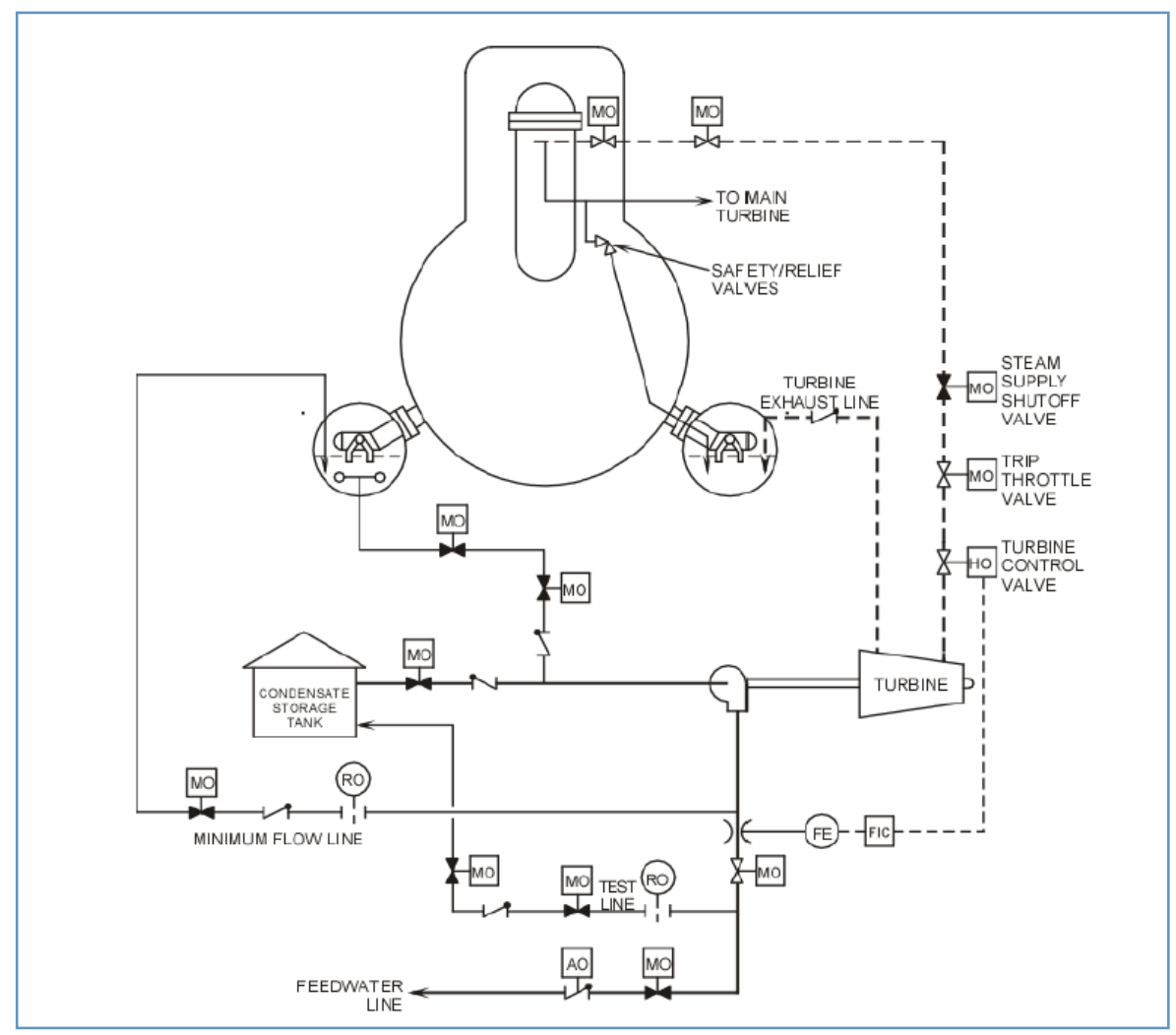

Fig. 5. Reactor core isolation cooling system.

\subsection{Isolation Condenser System}

The isolation condenser system (see Fig. 6) provides cooling for the reactor in the event that feedwater capability is lost and heat removal systems that require ac electrical power for operation are not available. The isolation condenser system is a closed system that removes reactor decay heat but conserves reactor water inventory. It operates by natural circulation without the need for driving power, other than the dc electrical system used to place the system in operation. When the isolation condenser is in operation, steam flows up from the reactor through the tubes of the condensers where it is condensed. The condensate returns by gravity to the reactor. The isolation condenser is placed in operation by opening the closed condensate return valve to the recirculation water system. During operation, the water on the shell side of the condenser will boil and vent to the atmosphere while condensing steam from the reactor inside the tube bundles. Makeup water to the shell side of the isolation condenser can be from many sources, including the fire protection system, if needed. 


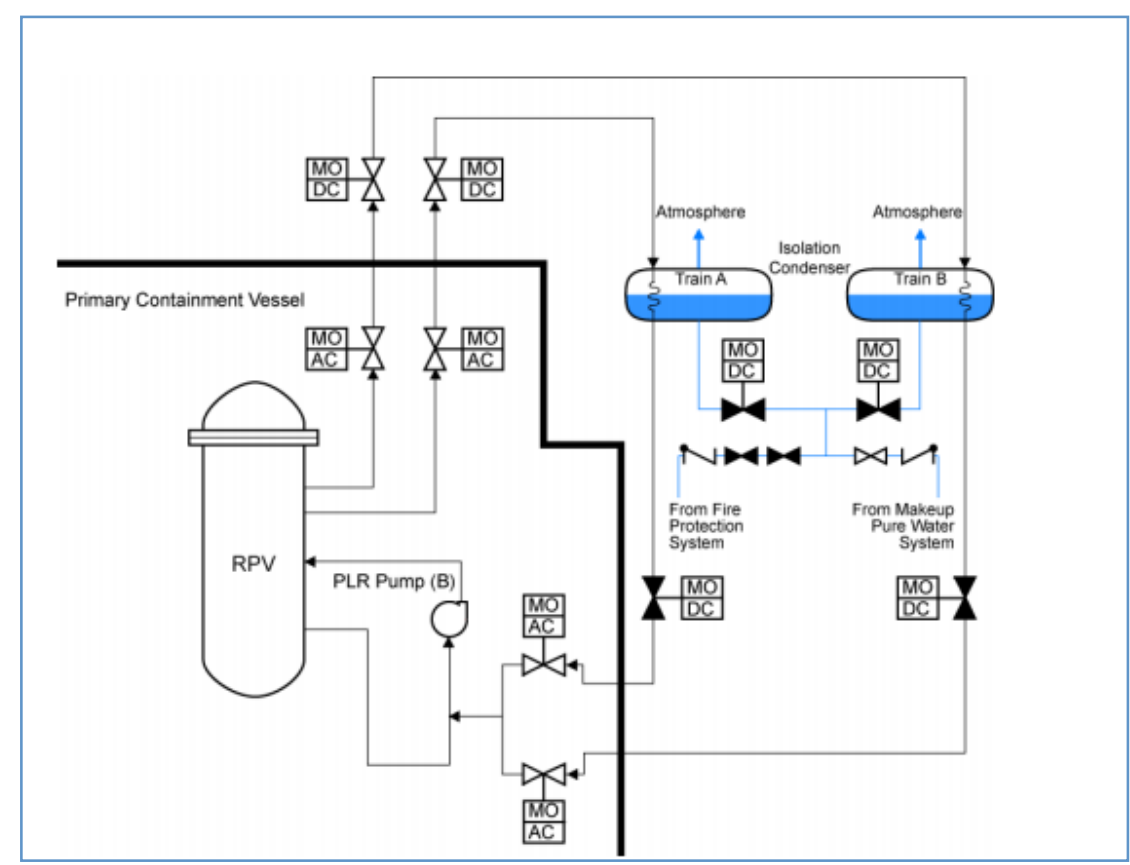

Fig. 6. Isolation condenser system (Ref. 7).

\subsection{High-Pressure Coolant Injection}

The HPCI system shown in Fig. 7 uses a high-pressure steam-driven pump to provide high pressure emergency core cooling capability. The flow rate $(\sim 5000-6000 \mathrm{gpm})$ of the system will maintain the reactor core adequately cooled until the reactor pressure drops sufficiently to permit the low-pressure core cooling systems to inject into the reactor. The HPCI system is automatically started on either a low-low water level in the reactor or a high drywell pressure. The normal supply of demineralized makeup water is from the condensate storage tank. The suppression pool is an alternate source of water. Steam supplied by the main steam system drives the turbine and is condensed in the suppression pool.

The I\&C system on the HPCI system manages system operation by monitoring system pressure, turbine speed, system flow, control and isolation valve positions, etc. Failure of the I\&C system typically results in loss of the system. Because the system is turbine driven, it does not require offsite or onsite electrical power as long as battery-based dc electrical power is available to power system I\&C equipment and valve positioning. 


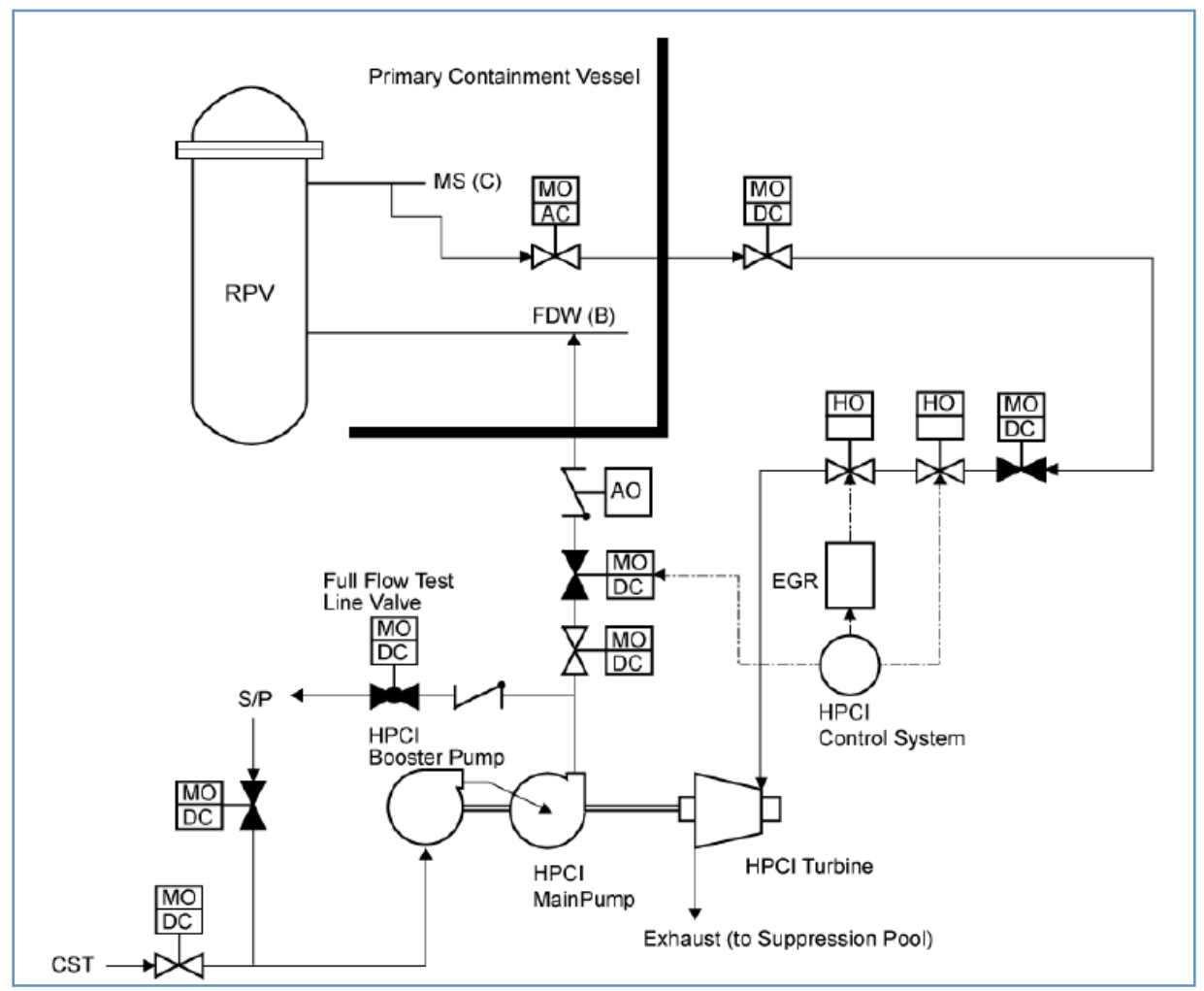

Fig. 7. High pressure coolant injection system (typical) (Ref. 8).

\subsection{Automatic Depressurization System}

In the event of a small LOCA or when the capacity of the high pressure injection systems is insufficient to maintain vessel water level, the safety/relief valves used for the ADS vent steam, reducing the reactor pressure and enabling the LPCI system to inject directly into the reactor vessel in time to cool the core and limit fuel temperature. The ADS relief valves relieve steam to the suppression pool.

\subsection{Core Spray System}

The core spray system is a LPIC system that provides water for the protection of the core for large break LOCA in which the high pressure injection systems have insufficient capacity to cool the fuel. The system typically has two independent loops of electric motor-driven pumps

\subsection{Low Pressure Coolant Injection System (and Residual Heat Removal System)}

The LPCI is one of several operating modes of the residual heat removal (RHR) system, which will also be described in this section. Other modes of the RHR systems are suppression pool cooling, drywell and suppression pool spray, shutdown cooling, and reactor vessel head spray. The LPCI is the dominant mode and normal configuration for the RHR system. The LPCI system operates when the pressure is sufficiently low to restore and maintain the coolant inventory after a LOCA so that the core is cooled. The LPCI pumps are electrically driven and take suction from the suppression pool and discharge to the reactor vessel core region through both recirculation loops as shown in Fig. 8 . LPCI flowrate is approximately $10,000 \mathrm{gpm}$ per pump, about 30,000 gpm total. 


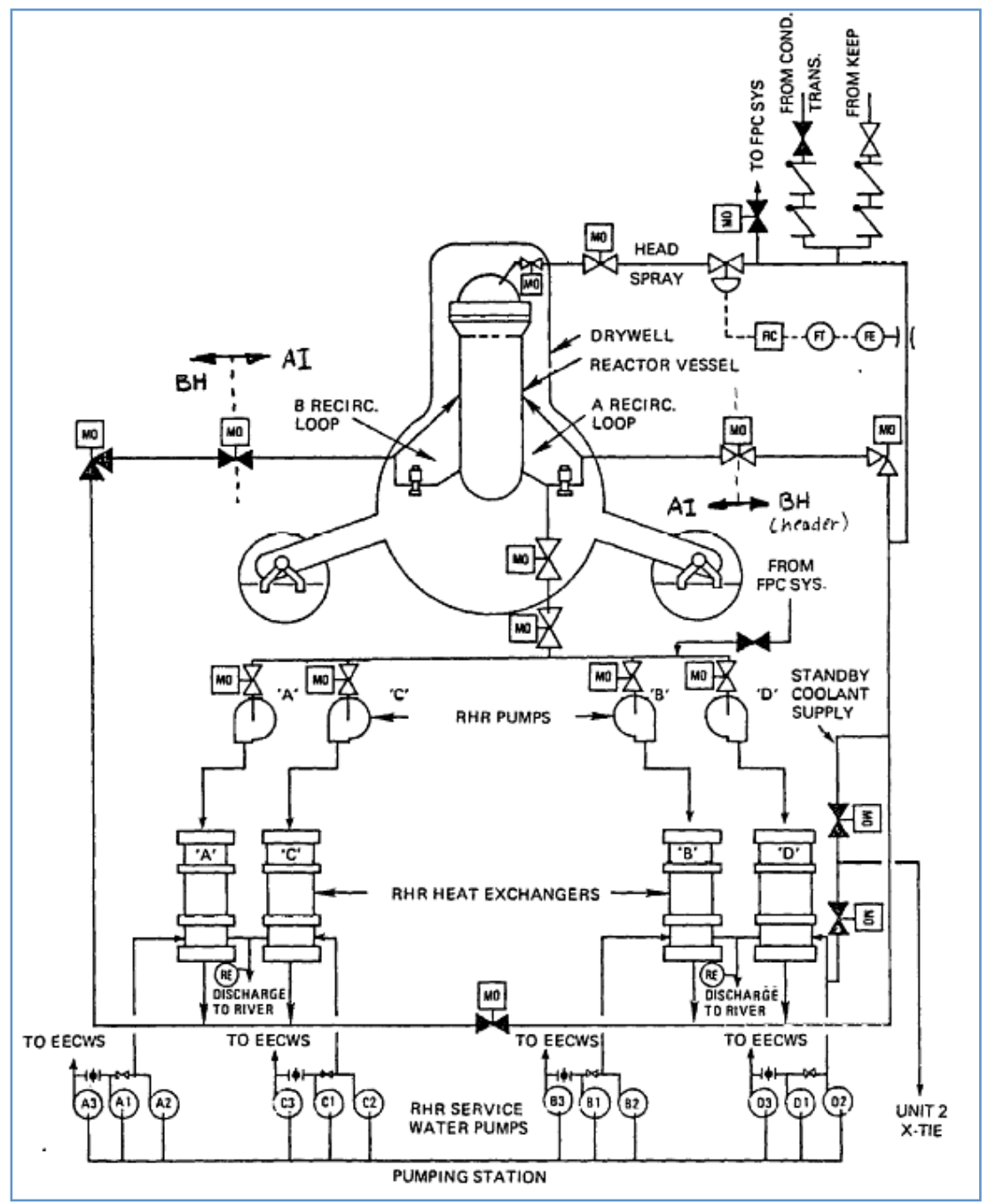

Fig. 8. Low pressure coolant injection system.

The suppression pool cooling mode of the RHR system prevents the suppression pool temperature from exceeding a certain value by circulating the hot suppression pool water through the RHR service water heat exchangers, which discharge their heat to the ultimate heat sink.

The drywell and suppression pool sprays prevent overpressurization of the containment following a LOCA. Water is pumped by motor-driven pumps from the suppression pool, where it is cooled in the RHR heat exchangers to spray headers where they discharge to the drywell or suppression pool. Sprays cool and condense steam in the drywell and thereby lower drywell pressure. Suppression pool sprays cool gases that collect in the free volume above the pool.

The shutdown cooling mode of the RHR system removes heat generated by the reactor core after the reactor has been shut down by circulating reactor water through the RHR heat exchangers. Part of this flow may be diverted to a spray nozzle in the reactor vessel head volume by condensing steam generated by the reactor vessel walls and internals. 


\subsection{Control Rod Drive Cooling Water System}

Although not an ECCS system, the control rod drive hydraulic system can provide flow in excess of the control rod drive seal cooling requirements to provide emergency, high-pressure makeup water to the reactor vessel-typically 40-60 gpm.

\subsubsection{Containment Integrity}

The BWR/4 Mark I containment is a multi-barrier pressure suppression containment. It serves as final barrier by which release of radioactive material is prevented - following fuel integrity and primary coolant system integrity barriers. The BWR Mark I primary containment consists of a drywell which encloses the reactor vessel and is connected by vent pipes to the suppression pool (see Fig. 9). The reactor building (or secondary containment) encloses the primary containment as shown in Fig. 10. The drywell is a steel pressure vessel with a spherical lower portion and a cylindrical upper portion. The top head is removable to access vessel internals and fuel. The steel drywell vessel is enclosed in reinforced concrete for shielding purposes and to provide resistance to deformation and buckling in certain areas. A gap of typically 2 in. is provided between the steel and concrete structures. Various penetrations are provided into the drywell to support personnel entry, equipment movement, and numerous piping, electrical, and instrumentation systems.

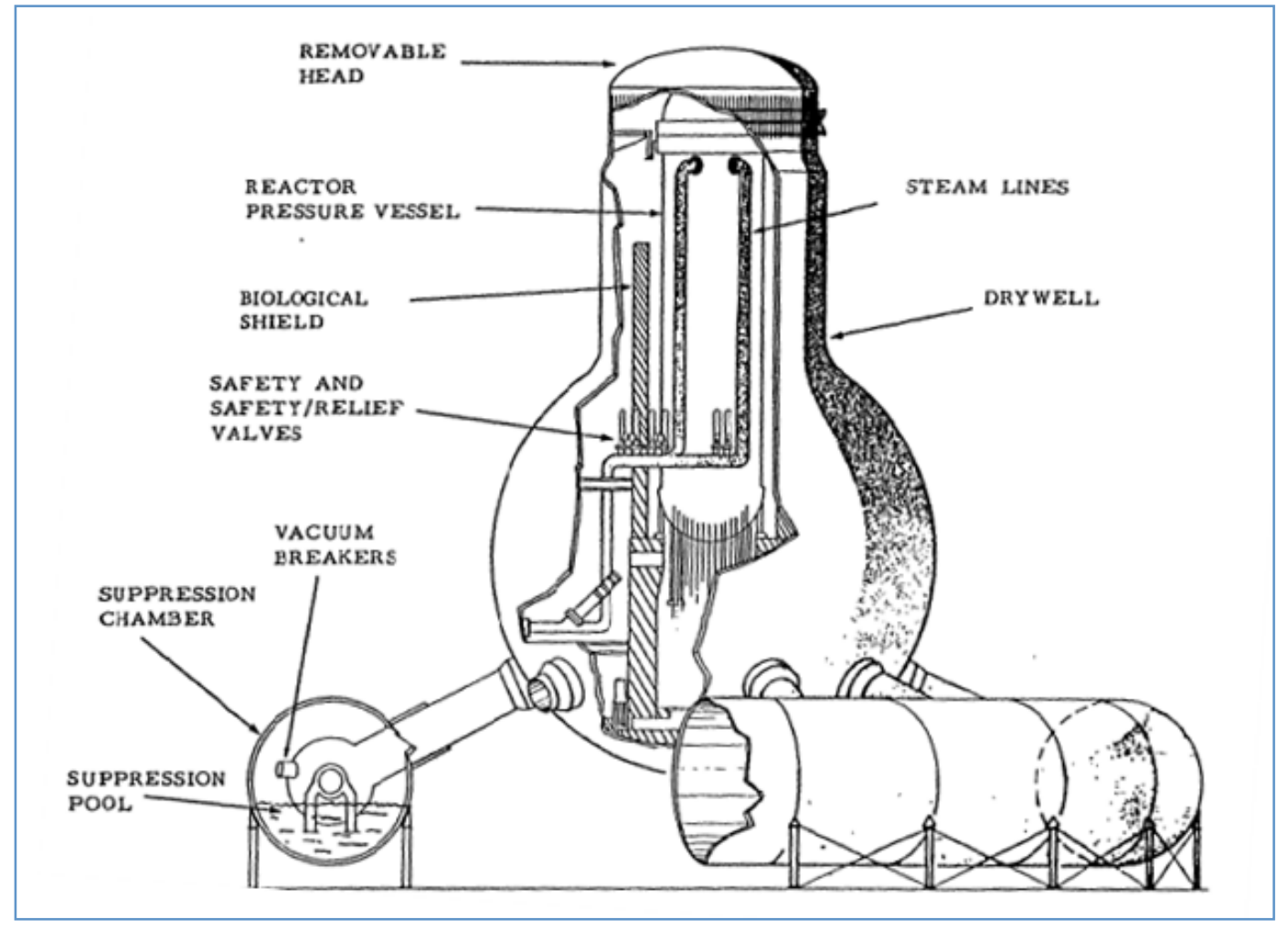

Fig. 9. Mark I drywell/torus containment design.

The pressure suppression pool (or chamber) is a steel pressure vessel just below and surrounding the drywell. Vent tubes from the drywell connect to a vent header concentric within the torus. Downcomer pipes extend from the vent header into the water of the suppression pool. In the event of a LOCA in the drywell, steam at pressure is vented into the suppression pool where it is condensed, and the high energy release of a LOCA is dissipated. 
The reactor building (or secondary containment) houses the primary containment structures; the spent fuel pool; and rooms that contain pumps, valves, heat exchangers, tanks, piping, instrumentation, coolers, ductwork, demineralizers, etc., that are part of plant operational and safety systems. The reactor building is maintained at a negative pressure relative to the environment to ensure that any radioactive contamination is contained within the building. Ventilation systems use exhaust filters to prevent the spread of radioactive contamination from the building.

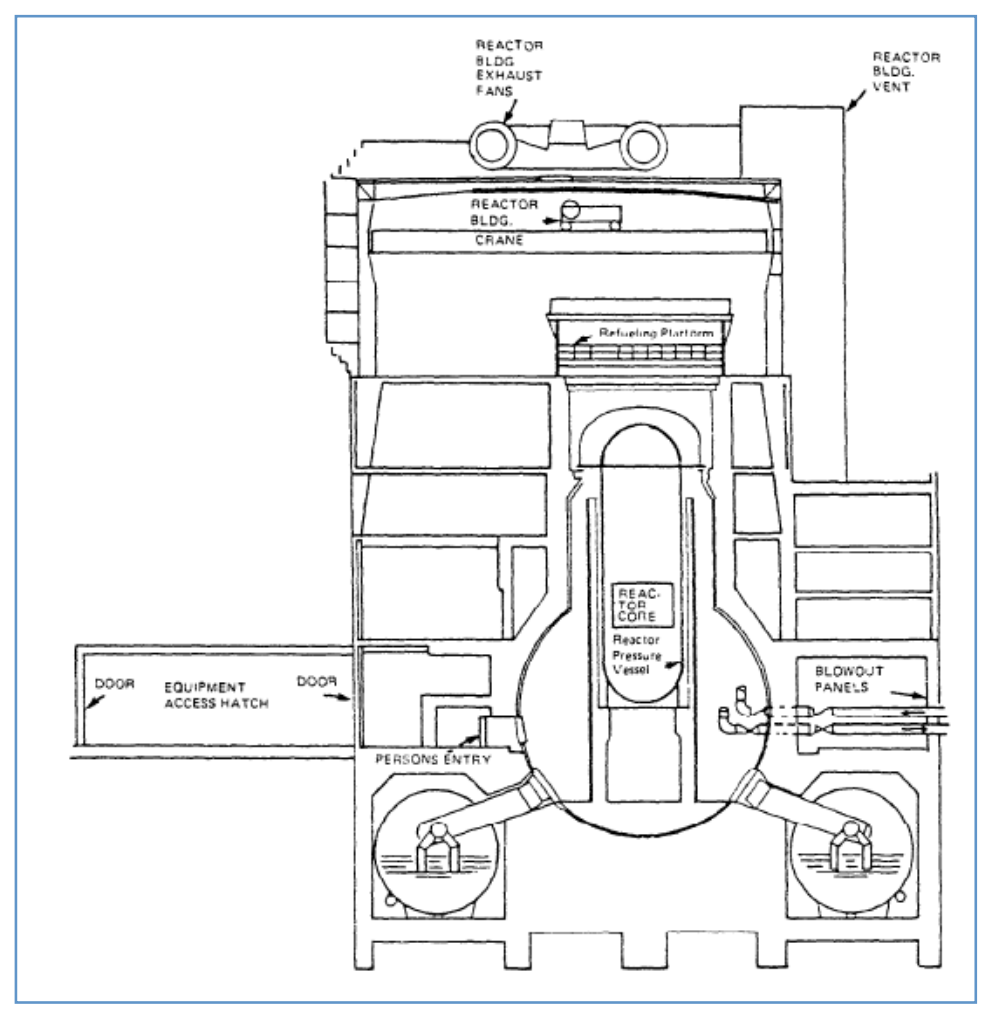

Fig. 10. Secondary containment.

\subsection{Containment Isolation}

The containment isolation system provides a means for isolating connection and interaction of systems and piping in the primary reactor systems within containment from systems and piping outside of containment. One of its purposes is to ensure that reactor coolant is retained in the reactor vessel in the event of a pipe break outside of containment. Another purpose is to ensure that radioactive materials resulting from an accident are not released to the outside environment. Various conditions result in containment isolations. Depending on the conditions, containment isolation valves for numerous systems close. Isolation valves for safety systems may open (or remain open) to permit these systems to function. Ventilation dampers may close and others may open, allowing ventilation under certain conditions but through various filtering systems. Containment isolation is also maintained through the use of numerous seals on penetrations for electrical cables, doorways, etc. All are designed for environmental conditions (e.g., temperatures, pressures, humidity, radiation levels, vibration, length of time) predicted for DBAs.

\subsection{Containment Venting}

The SBGTS system maintains secondary containment at negative pressure relative to the environment through use of electrically powered fans in order to provide a controlled, filtered, elevated release via 
the plant stack. This minimizes radioactive releases to the environment. This system is a safety system, so redundancy is provided for the system functions.

In addition, BWR Mark I containments typically have a hardened vent that directly connects the primary containment with the plant stack. This vent provides a means for relieving containment pressure in a controlled manner in the event of a severe accident (such as an dSBO during which electrically-powered cooling water pumps are inoperable) during which the containment is pressurized and for which normal containment pressure suppression systems (e.g., suppression pool, drywell spray) are not available.

\subsection{Containment Cooling}

During normal operation, the temperature of the drywell is maintained by multiple cooling units. Fans circulate drywell air through the coolers. Heat is rejected from the coolers to the reactor building closed cooling water system. Containment cooling functions during accident conditions are provided by water sprays to the drywell and suppression pool from the RHR system described in Section 2.2.2.3.6.

\subsubsection{Electrical Power Systems}

The purpose of the electrical systems is to provide power to operate the plant and to ensure that it is safely maintained in a shutdown condition when required. Power is provided by multiple, redundant, offsite, high-voltage power lines through which the plant also transmits power when it is operating. Multiple offsite power lines help to ensure that offsite power is available in the event of a failure or outage affecting one or more other lines. In the event of a loss of all offsite power, emergency diesel generators provide backup ac electrical power. Multiple, independent trains of emergency onsite ac electrical generation are provided. In addition, dc electrical systems provide power for instrumentation, control, and monitoring functions that require highly reliable power.

\subsection{Onsite ac Power Systems}

The ac electrical power systems provide power to plant equipment required for normal plant operations and to ensure that the reactor can be rapidly and safely shutdown and cooled, if required. High-voltage lines connect the plant to the power grid. Connections are made to multiple diverse sections of the power grid to ensure that a disturbance on one line for one part of the grid does not negatively affect all lines. The lines are capable of being quickly reconfigured or realigned to accommodate problems. Various power lines, cables, bus work, transformers, circuit breakers, protective relays, and switchgear route the power as needed. Normal auxiliary and alternate systems are provided to help ensure power from the power grid can be provided to the plant.

Transformers reduce voltage to power large motors and loads requiring medium voltage (e.g., $\left.4160^{\circ} \mathrm{V}\right)$. Voltage is stepped down further to power low-voltage equipment (e.g., 480 or $\left.120 \mathrm{~V}\right)$. The systems are designed with redundancy and independence to ensure that single failures of equipment do not cause a complete loss of a system. Circuits typically can be automatically or manually realigned or reconfigured to route around failed equipment.

Safety system loads are powered from safety buses. If safety bus voltage drops then the emergency diesel generators automatically start to repower those buses. Connections to normal bus power supplies are dropped and loads important to safety are reloaded by load sequencers to the safety buses. 


\subsubsection{2 dc Power Systems}

The dc power systems provide a highly reliable power supply to loads required by the reactor protection, ESF actuation system, emergency core cooling, containment isolation, alarms, communications, lighting, and radiation monitoring systems. The dc power system loads are normally provided from ac-powered battery chargers that are connected to a battery bank. Multiple trains provide redundancy. In the event offsite ac power is lost, emergency onsite diesel generators will power the battery chargers. If all ac electrical power is lost, the battery banks support dc bus loads until ac electrical power is restored or the batteries are exhausted.

\subsubsection{Important Support and Service Systems}

Several support systems are employed in BWRs to support normal and emergency plant conditions. These systems transfer heat from primary systems to the ultimate heat sink, ensure that operating environments for personnel meet habitability requirements, and control and extinguish fires. They frequently serve as buffer systems between a system in potential contact with radioactive materials and systems with direct contact with the environment.

\subsubsection{Component Cooling Water}

The component cooling water system, sometimes called the reactor building closed cooling water system, is an intermediate heat sink for heat removal of potentially radioactive heat loads during normal and emergency conditions. It supplies cooling water to various equipment in the plant and provides a barrier to limit potential releases of radioactive materials to the environment.

\subsubsection{Station Service Water}

The service water system is an open system, using water from the environment to service or cool various plant equipment or to cool an intermediate loop cooling water system.

The RHR service water system provides raw water to the RHR heat exchangers and provides standby core cooling. The RHR service water system provides water to the emergency cooling water system that supplies cooling water required for operation of the safety-related core spray system, RHR system, and diesel generator system. It also provides cooling water to the control room air conditioning system, reactor building closed cooling water system, and station service air compressors.

\subsubsection{Circulating Water System/Ultimate Heat Sink}

The circulating water system provides a means for rejecting heat from the main condenser to the environment. The RHR service water system pumps take suction from the circulating water system intake structure. The RHR service water system is therefore a safety system.

\subsubsection{Fire Protection System}

The high pressure fire protection system provides a source of relatively high-pressure raw water for fixed water spray or fog for certain equipment and to fire hydrants and hoses. Water may also be stored in elevated tanks.

\subsubsection{Building Habitability Control and Monitoring}

The environment in certain buildings and areas in the plant must remain habitable to ensure that plant operators are adequately protected against the effects of releases of toxic or radioactive gases. Safety- 
related equipment must also be maintained within certain environmental limits, such as temperature or adequate ventilation to ensure that it will satisfy its mission requirements.

\subsubsection{Essential Compressed Air System}

The essential compressed air system supplies dry, filtered air to safety-related systems and components.

\subsubsection{Accident Monitoring}

U.S. regulations (Ref. 9) require that plants have the I\&C systems necessary to monitor variables and systems over all anticipated ranges for accident conditions, provide a control room where actions can be taken to maintain the plant in a safe condition during accident conditions, and provide a means for monitoring radioactive releases as a result of an accident. Revision 4 of NRC Regulatory Guide (RG)1.97 describes a method that the NRC considers acceptable for complying with the agency's regulations pertaining to accident monitoring instrumentation through endorsement of IEEE Std 4972002 (with certain clarifying regulatory positions). This standard was written in part to provide a "consolidated source of post-accident monitoring requirements and bases for a new generation of advanced nuclear plant designs." It replaced a more prescriptive approach from Revision 3 of NRC RG 1.97, which provided a specific list of instrument variables to monitor. Given that the BWR/4Mark I plants are mature designs and were in use at the time when RG 1.97 Revision 3 was issued (1983), these variables will be highlighted in this section as being typical of those needed for accident monitoring, recognizing that licensees today have more freedom to select variables appropriate to their specific accident response requirements.

Variables to be monitored were broken into several categories and then specific types of variables listed for each category. The various categories and variables within the categories are described in the following sections. Note that variables can be in multiple categories.

\subsubsection{Reactivity Control}

Variables associated with neutron flux (from $10^{-6}$ to $100 \%$ full power), control rod position (full in or not full in), and reactor coolant system soluble boron concentration grab sample.

\subsubsection{Core Cooling}

Variables associated with core cooling are reactor vessel water level (from the bottom of the core support plate to the lesser of the top of the vessel or the centerline of the steam line), reactor core temperature (a provision considered in the early 1980s), RCIC flow (from $0-110 \%$ design flow), HPCI flow (from $0-110 \%$ design flow), core spray system flow (from $0-110 \%$ design flow), LPCI system flow (from $0-110 \%$ design flow), standby liquid control system flow (from $0-110 \%$ design flow), RHR system flow (from $0-110 \%$ design flow), and RHR heat exchanger outlet temperature (from $40^{\circ} \mathrm{F}$ to $350^{\circ} \mathrm{F}$ ).

Variables specifically associated with fuel cladding are radioactivity concentration or radiation level in circulating primary coolant (from 50\% to $100 \times$ technical specification limit) and gamma spectrum analysis of primary coolant (from $10 \mu \mathrm{Ci} / \mathrm{ml}$ to $10 \mathrm{Ci} / \mathrm{ml}$ or TID- 14844 source term in coolant volume).

\subsubsection{Reactor Coolant System Pressure Boundary Integrity}

Variables associated with reactor coolant system pressure boundary integrity are reactor coolant system pressure (from 0-1500 psig), drywell pressure (from 0 to design pressure), drywell sump level (top to bottom), primary containment area radiation (from $1 \mathrm{R} / \mathrm{h}$ to $10^{5} \mathrm{R} / \mathrm{h}$ ), and suppression pool water level (from bottom of ECCS suction line to $5 \mathrm{ft}$ above normal water level). 


\subsubsection{Containment Integrity and Containment Radiation}

Variables associated with containment integrity are primary containment pressure (from -5 psig to $4 \times[$ for steel] design pressure and from -5 to- 3 psig narrow range), suppression pool water level (from top of vent to top of weir well), suppression pool water temperature $\left(40-230^{\circ} \mathrm{F}\right)$, drywell atmosphere temperature $\left(40-440^{\circ} \mathrm{F}\right)$, drywell spray flow $(0-110 \%$ design flow $)$, primary containment isolation valve position (closed-not closed-excluding check valves), drywell hydrogen concentration (from 0 to 30 volume-percent, from -5 psig to design pressure), containment effluent radioactivity from release points including standby gas treatment vent (from $10^{-6} \mu \mathrm{Ci} / \mathrm{cc}$ to $10^{-2} \mu \mathrm{Ci} / \mathrm{cc}$ ), effluent radioactivity from buildings or areas where penetrations or hatches in direct contact with primary containment are located (from $10^{-6} \mu \mathrm{Ci} / \mathrm{cc}$ to $10^{3} \mu \mathrm{Ci} / \mathrm{cc}$ ), primary containment area radiation-high range (from $1 \mathrm{R} / \mathrm{h}$ to $10^{7} \mathrm{R} / \mathrm{h}$ ), and reactor building or secondary containment area radiation (from $10^{-}$ ${ }^{1} \mathrm{R} / \mathrm{h}$ to $10^{4} \mathrm{R} / \mathrm{h}$ for Mark 1 containments).

\subsubsection{Condensate and Feedwater System}

Variables associated with the condensate and feedwater system are main feedwater flow (0-110 percent design flow), condensate storage tank level (from top to bottom),

\subsubsection{Main Steam System}

Variables associated with the main steam system are main steam line isolation valve leakage control system pressure (0-15 in. water narrow range and $0-5$ psid wide range) and primary system pressure relief valve and ADS valve positions.

\subsubsection{Cooling Water System}

Variables associated with cooling water systems are cooling water temperature to ESF system components $\left(40-200^{\circ} \mathrm{F}\right)$ and cooling water flow to ESF system components (0-110\% design flow).

\subsubsection{Radwaste Systems}

A variable associated with the radwaste systems is the high- radioactivity liquid tank level (from top to bottom).

\subsubsection{Ventilation Systems}

A variable associated with ventilation systems is emergency ventilation system damper position (open-closed status).

\subsubsection{Power Supplies}

Variables associated with the status of standby power and other energy sources important to safety (e.g., electric, hydraulic, pneumatic) voltages, currents, pressures, etc., are plant specific.

\subsubsection{Area Radiation}

A variable associated with area radiation monitoring is radiation exposure rate inside buildings or areas where access is required to service equipment important to safety (from $10^{-1}-\mathrm{R} / \mathrm{h}$ to $10^{4} \mathrm{R} / \mathrm{h}$ ).

\subsubsection{Airborne Radioactive Materials Released from Plant}

Variables associated with monitoring airborne radioactive noble gases released from the plant are drywell purge and standby gas treatment purge (from $10^{-6} \mu \mathrm{Ci} / \mathrm{cc}$ to $10^{5} \mu \mathrm{Ci} / \mathrm{cc}$ for $0--110$ percent vent design flow), secondary containment purge (from $10^{-6} \mu \mathrm{Ci} / \mathrm{cc}$ to $10^{4} \mu \mathrm{Ci} / \mathrm{cc}$ for $0--110$ percent 
vent design flow), auxiliary buildings containing primary system gases such as decay tanks (from $10^{-6}$ $\mu \mathrm{Ci} / \mathrm{cc}$ to $10^{3} \mu \mathrm{Ci} / \mathrm{cc}$ for $0-110 \%$ vent design flow), and common plant vent (from $10^{-6} \mu \mathrm{Ci} / \mathrm{cc}$ to $10^{3}$ $\mu \mathrm{Ci} / \mathrm{cc}$ for $0-110 \%$ vent design flow).

Variables associated with monitoring airborne radioactive particulates or halogens from all identified plant release points (from $10^{-6} \mu \mathrm{Ci} / \mathrm{cc}$ to $10^{2} \mu \mathrm{Ci} / \mathrm{cc}$ for $0-110 \%$ vent design flow).

\subsubsection{Environs Radiation and Radioactivity}

Variables associated with airborne radiohalogens and particulates (portable sampling - from $10^{-9}$ $\mu \mathrm{Ci} / \mathrm{cc}$ to $10^{-3} \mu \mathrm{Ci} / \mathrm{cc}$ ), plant and environs radiation (portable instrumentation-from $10^{-3} \mathrm{R} / \mathrm{h}$ to $10^{4}$ $\mathrm{R} / \mathrm{h}$, photons $10^{-3} \mathrm{rads} / \mathrm{h}$ to $10^{4} \mathrm{rads} / \mathrm{h}$, beta radiations and low-energy photons).

\subsubsection{Meteorology}

Variables associated wind direction $\left(0-360^{\circ}\right)$, wind speed (0 - $\left.22 \mathrm{mps}\right)$, and estimation of atmospheric stability based on vertical temperature difference from primary meteorological system.

\subsubsection{Accident Sampling}

Variables associated with primary coolant and sump sampling are gross activity (from $1 \mu \mathrm{Ci} / \mathrm{cc}$ to 10 $\mathrm{Ci} / \mathrm{cc})$, gamma spectrum (isotopic analysis), boron content (0-1000 ppm), chloride content (0-20 $\mathrm{ppm})$, dissolved hydrogen or total gas (0-2000 cc(STP)/kg), dissolved oxygen (0-20 ppm), and pH (113).

Variables associated with containment air sampling are hydrogen content ( 0 -10 volume-percent, $0-30$ volume percent for inerted containments), oxygen content (0-30 volume-percent), and gamma spectrum (isotopic analysis).

\subsubsection{Reactor Vessel Temperature}

A number of thermocouples (46 for a representative BWR vessel as shown in Fig. 11) measure reactor vessel temperature to monitor various vessel components to assess vessel stresses during heatup and cooldown. 


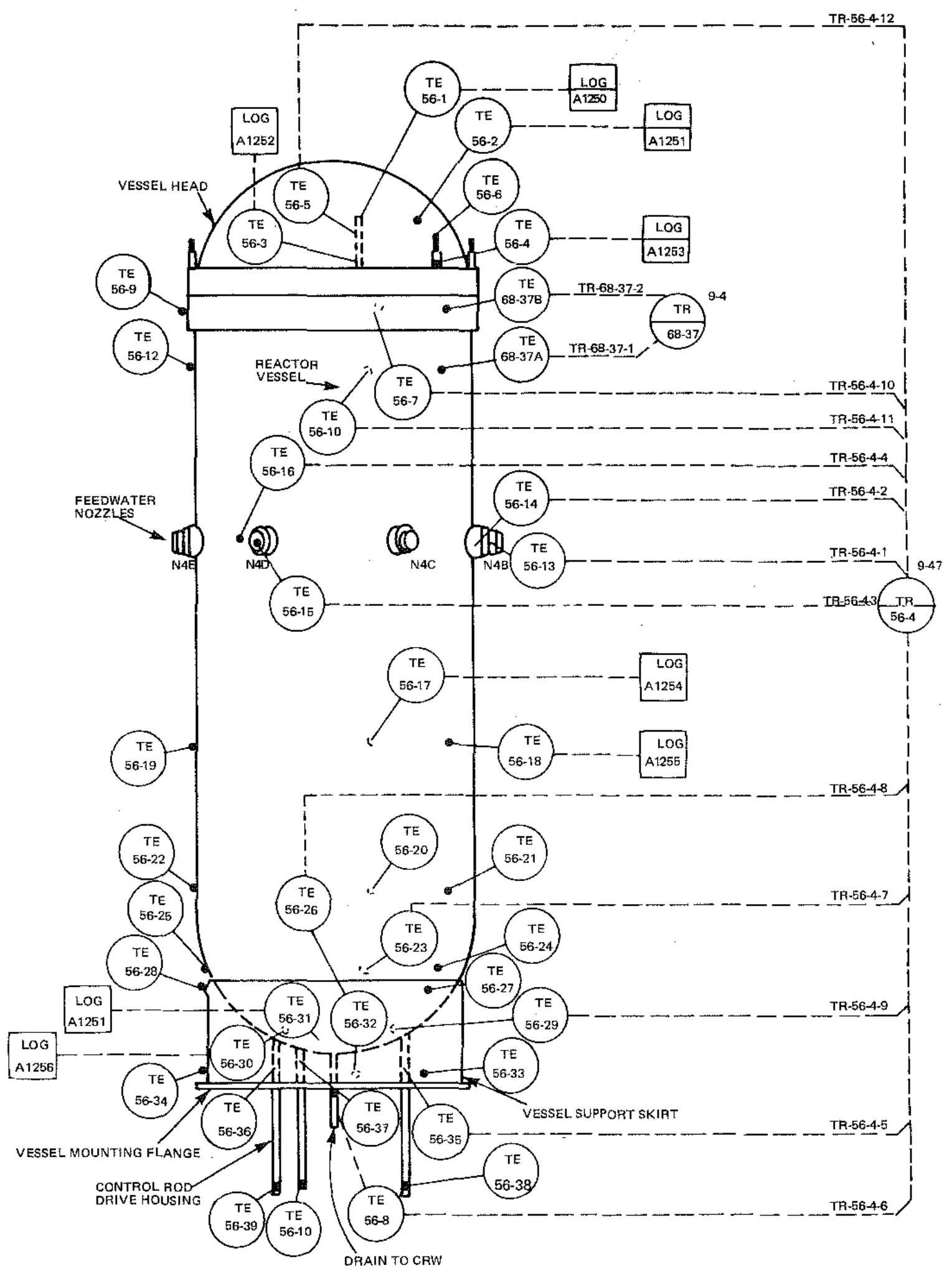

Fig. 11. Reactor vessel temperature indicators. 



\section{REPRESENTATIVE SEVERE ACCIDENT RESEARCH: PARAMETER NEEDS AND INSTRUMENTATION PERFORMANCE}

This section briefly describes representative early research activities that highlighted instrumentation needs and vulnerabilities in severe accidents. It is provided to highlight some of the instrumentation deemed particularly valuable to plant operations staff, identify information needs not available during severe accidents, and to identify particular instrumentation vulnerabilities that were noted at the time of the research activities.

Plant I\&C systems are designed to provide necessary information to the reactor protection system, ESF actuation system, and operator information needs in the control room so that the plant is shutdown and cooled under normal operational transients and accident conditions. These instrumentation systems are designed with principles of redundancy, diversity, and defense in depth to ensure their availability and performance. They are necessary to inform and guide operating staff in understanding the nature and ongoing consequences of events and challenges to the plant and to assess the performance and condition of automatic systems. Timely and accurate information is key to implementing correct actions to prevent serious events, reduce their consequences, and inform accident responses. Severe accidents can certainly be postulated that threaten the performance of the instrumentation systems and the plant systems, operator actions, and accident monitoring functions they support.

\subsection{Types of Severe Accidents}

Many research activities were carried out regarding BWR severe accidents since the 1980s following the accident at TMI-2 in March 1979 (Ref. 10). Research examined accident scenarios including SBO, small break LOCA, loss of decay heat removal (LDHR), and anticipated transient without scram (ATWS). These were representative of potentially risk-significant scenarios identified in early risk studies, such as the WASH-1400 Reactor Safety Study (Ref. 11).

These topics were well studied. Appendix A provides a partial bibliography of LWR safety research activities carried out at Oak Ridge National Laboratory from the mid-1970s until about 2010. Other national laboratories and organizations also carried out extensive U.S. government-funded and industry funded studies on these topics. International institutions and organizations performed similar research as well.

\subsection{Accident Information Needs}

Evaluation of accident scenarios (Ref. 12) in this early research, of which NUREG/CR-2182 is an example, confirmed the vulnerability of instrumentation in severe accidents. That report, which assesses SBO (loss of all AC electrical power-DC electrical power systems function until battery depletion in this scenario). The scenario moves to a severe accident with core damage when the battery-powered dc electrical system loses power, and the ability to monitor plant conditions and implement certain functions necessary to inject water into the core is lost. Alternative de electrical power sources could provide drywell temperatures and reactor vessel temperatures for a longer period, perhaps giving indication of core uncovery. Mechanical level indicators available locally in the reactor building could also provide information about pending core uncovery. Essentially all accident monitoring capabilities would be lost as remaining battery power is depleted.

The information needed to manage severe accidents for BWRs with a Mark I containment was examined by research in the 1991 time period noted in NUREG/CR-5702 (Ref. 13). This research 
compared instrumentation capabilities with projected needs during severe accidents (assuming the instrumentation is itself powered), and recognizes the potential for instruments to provide misleading information owing to exposure to conditions outside environmental qualifications. Appendix A to NUREG/CR-5702 provides comprehensive tables of information needs to be obtained, either directly or indirectly, by existing plant instrumentation. Approximately, 140 unique parameters considered important for accident management purposes were listed. Approximately, 20 different parameters were noted for which there was not a direct information source-indirect information sources may be available in some cases. Table 2 summarizes these information needs.

Table 2. Additional BWR Mark I information needs

\begin{tabular}{|l|l|}
\hline \multicolumn{1}{|c|}{ Information need } & \multicolumn{1}{c|}{ Direct information source } \\
\hline Control rod material location & None \\
\hline Core damage status & None \\
\hline Core materials and geometry & None \\
\hline Core melt location in drywell & None \\
\hline Core relocation status & None \\
\hline Drywell concrete ablated & None \\
\hline Drywell fission production concentration & None \\
\hline Drywell heat removal rate & None \\
\hline Drywell presence radiolytic products in water & None \\
\hline Drywell shell temperature & None \\
\hline Drywell water level & None \\
\hline Drywell/suppression chamber interface integrity & None \\
\hline Flow rate to condenser & None \\
\hline Fuel rod temperature & None \\
\hline Heat sink energy removal rate & None \\
\hline Interfacing systems pipe rupture location & None \\
\hline Nitrogen concentration & None \\
\hline Non-condensibles in drywell & None \\
\hline Primary containment integrity & None \\
\hline Safety relief valve tailpipe integrity & None \\
\hline Suppression pool break location status & None \\
\hline $\begin{array}{l}\text { Suppression pool inadequate heat removal } \\
\text { capacity }\end{array}$ & None \\
\hline Suppression pool spray flow rate & None \\
\hline Vessel integrity & None \\
\hline
\end{tabular}

Several important observations or conclusions were highlighted, including the following:

- There is insufficient information to determine whether containment remains inert (e.g., nitrogen concentration in the drywell). This information could inform decisions on containment venting in which a release of hydrogen could cause a deflagration or detonation.

- There is insufficient information to determine whether molten material has penetrated the containment vessel (e.g., drywell shell temperature or the amount of drywell concrete that has been ablated).

- There is insufficient information to ensure containment integrity noted relative to two items. The integrity of the safety relief valve tailpipe is not measured. If the tailpipe fails, then the containment would be subject to elevated pressures. This was noted to be an unlikely failure, 
but one that would help ensure containment integrity. Also, placing instruments to detect containment leakage would be difficult given the number and variety of containment penetrations. This was not considered practical.

- Eleven information needs could mislead accident management personnel. Three were categorized as more important:

- Core relocation status: Unambiguous information regarding status of the core as core damage is occurring - some indirect measurements do exist

- Drywell and heat sink heat removal rates: The placement and interpretation of indirect measurements should be carefully examined as direct measurements were noted as not practical

- Interfacing systems pipe rupture location: Responses to breaks or leaks - closing valves or flood break locations - depend on knowing where they occur. A leak detection system typically detects leaks in high temperature systems and may not be effective for broad, changing conditions because of difficulty in determining actuation set-points to detect small leaks without triggering false alarms

A subsequent related report (Ref. 14) specifically addressed instrument availability during severe accidents for a BWR with a Mark I containment. The report reiterates the necessity of timely and accurate information provided by plant instrumentation to monitor plant status and to guide preventative and mitigative actions. The objectives of this research included the identification of plant conditions that could affect instrument performance and information needs, definition of envelopes of plant parameters for a broad range of accident sequences to assess instrumentation availability, and then assessment of the availability of plant instrumentation during severe accidents. The assessment was based primarily on the environmental qualification limits, instrument ranges, and availability of backup power for the instruments.

An important assumption was that instrument performance would be degraded or failed if environmental qualifications (magnitude of condition and length of time) were exceeded or if the measured parameters were outside the instrument range. Erroneous readings could precipitate inappropriate operator actions or cause undesired changes in state of systems, such as erroneously starting or stopping.

The report included tables (Tables 5-6) repeated in Appendix B. Table 5 in Appendix B of this report is a list of instrumentation and its potential availability during a severe accident at the Peach Bottom plant pertinent to RG 1.97. Table 6 in Appendix B lists two instruments, reactor building temperature and reactor building pressure, that were not listed in RG 1.97. In these tables, Category 1 instruments are those that are fully environmentally qualified, are redundant, provide real-time display, and have standby power (not necessarily battery backup). Category 2 instrumentation meets less stringent qualifications - it may not be seismically qualified, may not have redundant continuous display, and may not have standby power. Category 3 instrumentation is the least stringent, being high-quality commercial-grade equipment powered only by offsite power. This table is representative of Peach Bottom at the time; the report notes that loads and backup power sources can vary widely by plant.

The results from the excerpted tables in Appendix B can be summarized as follows:

- Severe conditions in the reactor system prior to core damage can potentially affect the availability of instruments for

- reactor pressure and water level

○ drywell pressure, sump level, spray flow rate, and atmosphere temperature

- suppression pool water temperature, pressure, and spray flow rate 
○ drywell and reactor building isolation valve position

- containment and drywell hydrogen and oxygen concentration

- containment area radiation

- standby liquid control system pressure and storage tank level

- safety relief valve position or flow

○ RCIC, HPCI, core spray, LPCI, and RHR flow

○ RCIC and HPCI room temperature

- RHR heat exchanger outlet temperature

○ vent stack monitoring

- status of power (electrical and other)

- Severe conditions after core damage can potentially affect the availability of instruments for

- reactor pressure and water level

- suppression pool water level and spray flow rate

- drywell pressure and spray flow rate

- reactor building isolation valve position;

○ containment and drywell oxygen and hydrogen concentration

- standby liquid control system pressure and storage tank level

- RCIC, HPCI, core spray, LPCI, and RHR flow

○ RCIC and HPCI room temperature

○ RHR heat exchanger outlet temperature

○ vent stack monitoring

- status of power (electrical and other)

- Severe reactor building conditions can potentially degrade almost all of the accident monitoring requirements listed except (1) containment gas and reactor coolant grab sampling and (2) flow rates, tank levels, etc., from equipment located in the turbine building or outside of the reactor building.

The research concluded that pressure and temperature conditions, even before core damage, can greatly affect instrument availability for certain severe accidents. Problems with containment venting could lead to severe reactor building conditions (if hardened vents are not used, or have insufficient capacity, such as for ATWS conditions). Radiation exposure could affect instrument performance during a long-term accident. To summarize the conclusions

- After the onset of core damage, neutron monitoring instrumentation temperature limits in the core will be exceeded and performance will degrade. Components of this system are also located in the drywell where pressures and temperatures above environmental qualification values may also degrade performance

- Drywell and torus conditions beyond qualification limits could degrade instrumentation located in the drywell and torus 
- Reactor vessel failure could create environmental conditions that degrade instrumentation located in the reactor vessel

- Severe reactor building conditions resulting from containment failure or failures of nonhardened vents could affect instrumentation that monitors the reactor coolant system and containment

It was noted that instrumentation that monitors the reactor coolant system and containment would be available until their power supplies (dc power with battery backup) were depleted or environmental limits were exceeded. Sampling systems may not be available in a SBO.

Accident management information needs were also being addressed internationally during this time period. As an example of numerous international research results, a report describing severe accident instrumentation needs of the Finnish TVO BWR (Ref. 15) noted the addition of instrumentation to:

- indicate and alarm hardened vent rupture disk actuation

- indicate containment pressure, reactor pressure, water level inside the lower drywell, and drywell/wetwell pressure difference to help prevent early containment failure

- indicate dose rate in drywell/wetwell, water level in containment, and containment pressure to help control and limit releases

- indicate containment water level and pressure to help achieve a safe, stable state.

The instrumentation was to remain capable for $24 \mathrm{~h}$ following a loss of all ac power, withstand severe accident environmental conditions (including seismic); be provided in parallel, redundant channels; be safe from damage from molten core material; provide protection against sensing line damage from missile impacts; have transmitters located outside containment in rooms free from process system components; and provide measurement indications on a special emergency monitoring panel close to an emergency exit of the reactor building. 



\section{FUKUSHIMA DAIICHI ACCIDENT}

On March 11, 2011, at 1446 Japan time, an earthquake occurred on the east coast of northern Japan. The Tohoku earthquake, measuring 9.0 on the Richter scale, was one of the largest earthquakes in recorded history and the largest ever experienced in Japan. At the six-unit Fukushima Daiichi Power Station on the east coast of Japan, Units 4-6 were shut down for outages, but Units 1-3 were operating. These units shut down automatically on seismic reactor protection system trips. The earthquake caused extensive damage to offsite power systems, resulting in a loss of offsite power to the station. Emergency diesel generators started automatically and provided ac electrical power to plant emergency systems, which responded as designed to begin cooling the units to cold shutdown. Minutes later a major tsunami warning was sounded. About 40 minutes later, a series of seven tsunami waves began arriving, inundating coastal areas, devastating structures, and directly causing the death of more than 20,000 people. Tsunami waves of approximately $45 \mathrm{ft}$ in height, $30 \mathrm{ft}$ higher than the station was designed for, struck the Fukushima Daiichi station and destroyed much site infrastructure - such as circulating water pumps (the ultimate heat sinks), numerous tanks, equipment, and facilities - and flooded critical systems. As a consequence, almost all onsite power at the station was lost, and the three operating plants lost core cooling to remove decay heat. Over the next few days, three reactor cores were severely damaged, explosions rocked three reactor buildings, and onsite and offsite radiation releases led to large-scale population evacuations.

Details of the Fukushima Daiichi accident have been reported in numerous high-level investigations (Refs. 16-26). The purpose of this report is to address instrumentation failures, degradation, or deficiencies. Portions of the accident sequences that are relevant to instrument performance will be examined. Other aspects of the accident may be reviewed in the referenced documents.

\subsection{ACCIDENT SEQUENCE PROGRESSION}

The performance of the important instrumentation systems at Units 1-3 is the subject of this review. Significant attention has been devoted to the spent fuel I\&C affecting the Unit 4 spent fuel pool (see the NRC Near-Term Task Force Report [Ref. 18], Recommendation 7); therefore, Unit 4 issues are not addressed in this report. Units 5 and 6 were able to share an operable air-cooled emergency diesel generator and maintain monitoring systems and shutdown cooling; therefore, Units 5-6 issues are also not addressed in this report.

Overviews of the responses of Fukushima Units 1-3 excerpted from the main body of the Tokyo Electric Power Company (TEPCO) report (Ref. 17) are provided in Appendix C. The accident progression for Units 1-3 is shown in Figs. 12-14. (Acronyms are defined in the main body of the TEPCO report.) The event overviews shown in Appendix $C$ as well as the detailed accounts also provided in the TEPCO report were examined. The Institute for Nuclear Power Operations report (Ref. 24) was also helpful in identifying instrument performance problems.

The accident progression will be reviewed as it pertains to instrumentation performance for each unit for three time periods: (1) from the reactor trip to the total SBO due to the tsunami, (2) from the tsunami until the restoration of power through portable generators or new cables to offsite power sources at approximately the time of the Units 3-4 explosions, and (3) post-power restoration until about the end of March 2011, when conditions at the units were somewhat stabilized. Precise distinctions between the units will not be made because of the similar conditions affecting the instrumentation systems at each unit. 


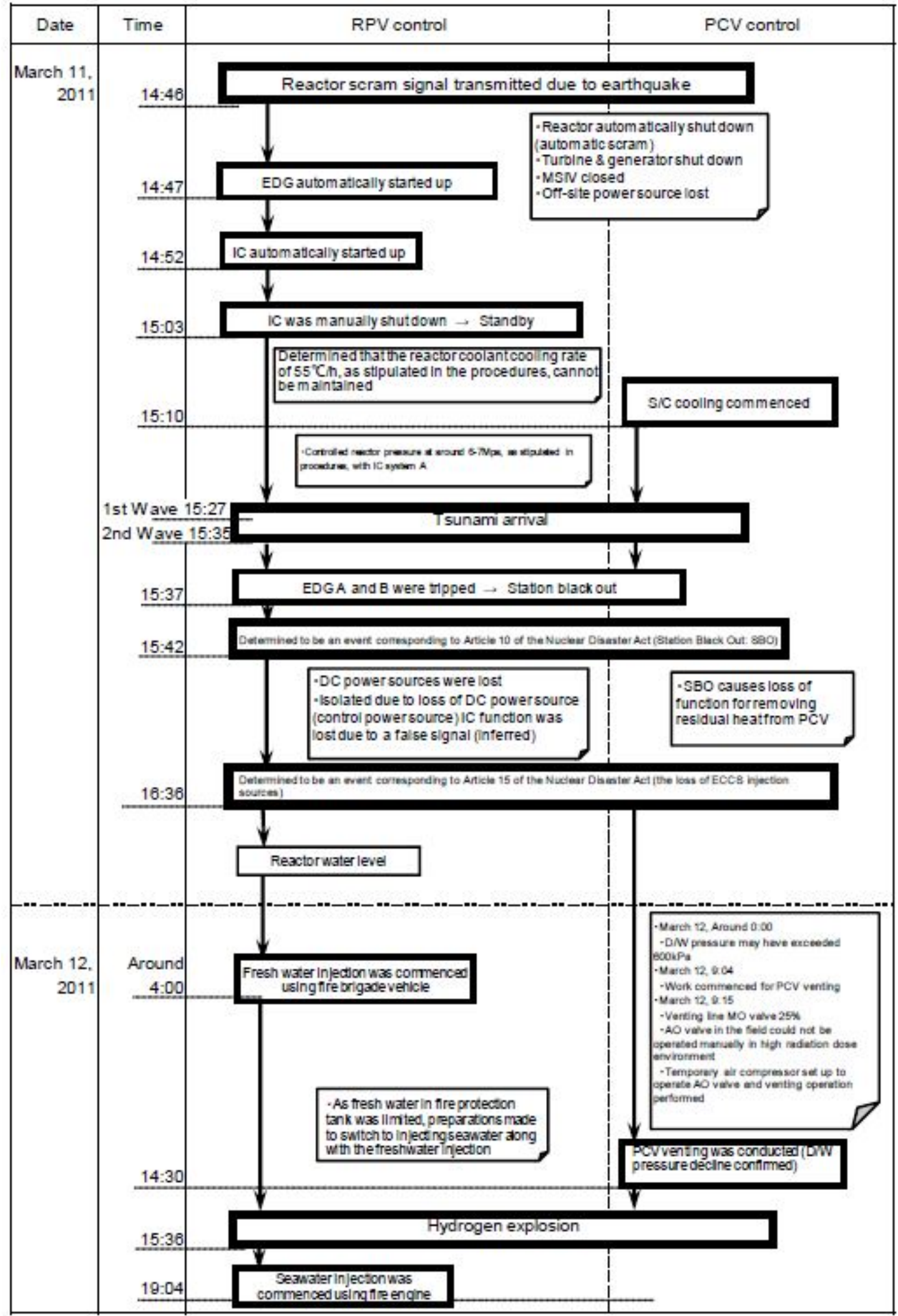

Fig. 12. Fukushima Unit 1 event progression summary (TEPCO [Ref. 17], p. 179). 


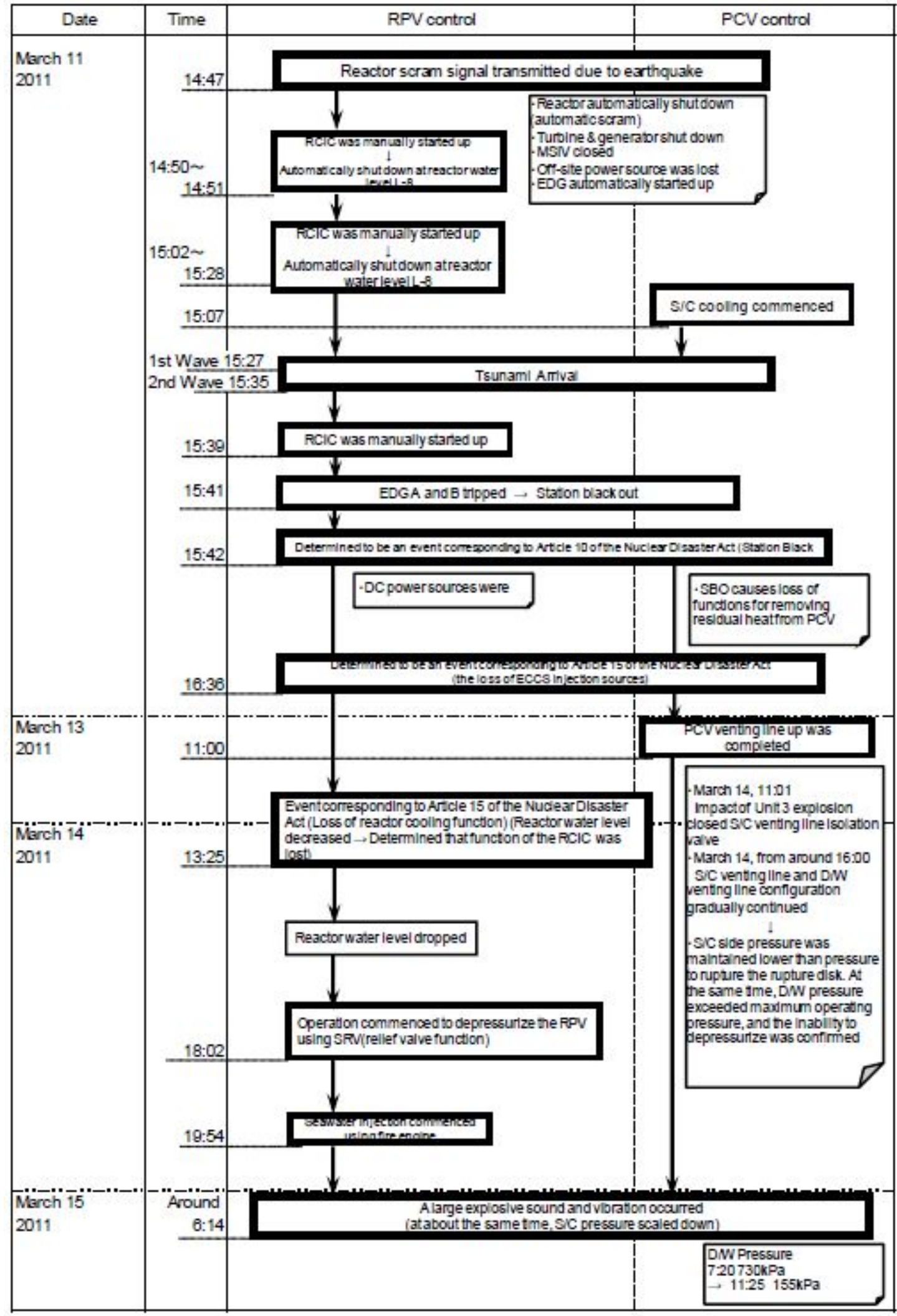

Fig. 13. Fukushima Unit 2 event progression summary (TEPCO [Ref. 17], p. 212). 


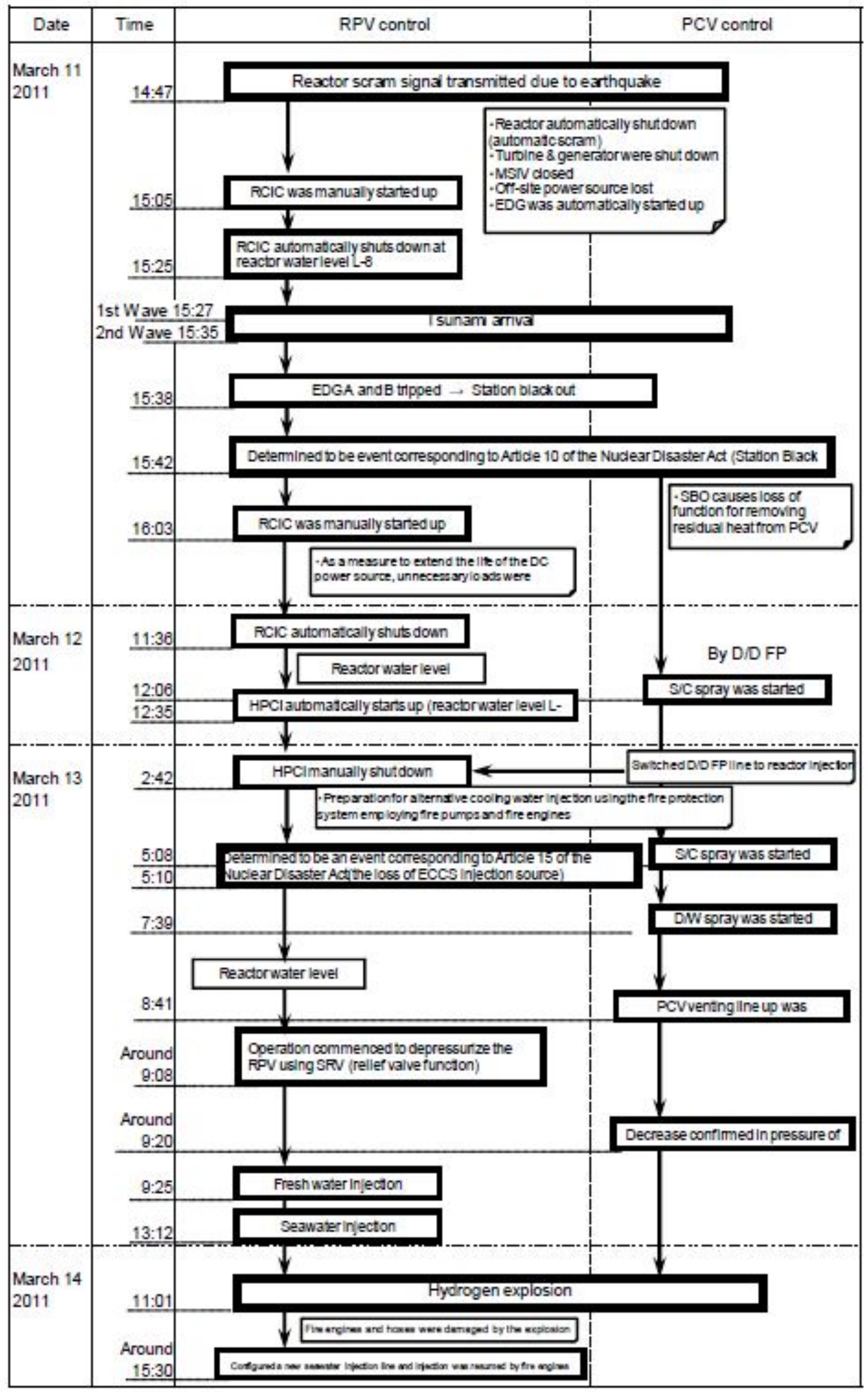

Fig. 14. Fukushima Unit 3 event progression summary (TEPCO [Ref. 17], p. 237). 


\subsection{INSTRUMENTATION PERFORMANCE SUMMARY}

The safety philosophy of today's operating nuclear power plants is based on principles of diversity, redundancy, and defense in depth to provide assurance that if there is a problem with the function of one safety system, there is another effective means to accomplish the function of that system. These systems in today's plants are active systems that depend on actuation of motors, turbines, pumps, relief valves, heat exchangers, coolers, etc., to enable core decay heat to be transferred from the core to the ultimate heat sink. Instrumentation and control systems ensure these systems are actuated as needed and perform within their design requirements (turbine speeds, pump flows, overcurrent/overtemperature protection, etc.). Flooding from the tsunami knocked out all power to Units 1-4-offsite ac electrical power, emergency onsite ac electrical power, and onsite dc electrical power. Power for the motors, pumps, valves, coolers, etc., of the active systems was lost. Power to monitoring and control systems, control room displays and indicators, lighting, and communications was lost. The ability to remove decay heat to cool the reactor cores was lost in spite of heroic attempts to connect temporary power sources and engineering workarounds. Gradually, and in an often piecemeal and sporadic fashion, operators reestablished some monitoring and indication functions at reactor building panels and in the control room. Valve manipulations in challenging reactor building locations were carried out with the aid of hand-carried batteries, electric generators, and bottled gas or air compressors.

\subsubsection{Time Period: Earthquake to Tsunami}

In summary, Units 1-3 responded as designed to the earthquake and its immediate consequences. The units scrammed on seismic readings as designed. As offsite ac electrical power systems were disabled by the earthquake, onsite emergency diesel generators started, loaded emergency buses, and powered safety-related cooling systems as designed. All plants were on expected paths to cold shutdown, as designed. Plant monitoring and I\&C systems performed as designed. Operator actions were as expected. The response to this significant design basis event was as designed.

For Unit 1, the isolation condenser was used to control reactor pressure and remove decay heat. Reactor water level was maintained since the isolation condenser is a closed-loop system.

For Units $2-3$, the reactor steam-driven reactor core isolation cooling system was used to maintain reactor vessel water level and remove decay heat by routing turbine exhaust steam to the suppression pool. Suppression pool spray and cooling systems were started to remove this heat from the suppression pool to the ultimate heat sink.

\subsubsection{Time Period: Tsunami to Reactor Building Explosions}

About 40 minutes after the earthquake, the first of seven tsunami waves hit the site. Flood waters 15 feet above grade level inundated the first floors of the turbine building and service building, knocking out the emergency diesel generators, dc electrical power system batteries, and power distribution panels. Motorized equipment was lost, as were monitoring instruments. Building and control room lighting was lost. Communications within and outside the plants' control rooms were lost. Devastation to the site was severe, greatly hindering recovery actions, as described by the various accounts of the accident and the account summaries in Appendix C.

During this time period, operators attempted to restore control room functions, monitor the plant to gain knowledge of important unit conditions, and reestablish core cooling and vent containment. Critical information needs during this time were RPV level and pressure, drywell pressure, and suppression pool pressure. Critical control needs were the operability of high pressure injection and cooling systems and the ability to depressurize the reactors and vent containment so that low-pressure injection systems could be established. 


\section{Unit 1}

For Unit 1, valve position indication for the isolation condenser displayed intermittently. Operators attempted control of this important system, but valve isolations of ac- and dc-powered valves prevented the system from operating effectively, if at all. Without dc electrical power, HPCI was unavailable. Because main control room monitors and indicators were lost, plans were made to obtain readings at instrument racks in the reactor building and to confirm the locations of valves to be used for containment venting. Harsh reactor building conditions limited the ability to read instrumentation and perform work activities. A reactor vessel pressure reading at a reactor building location at 20:50 on March 11 was $6.9 \mathrm{MPa}$. A reactor vessel level reading at 21:19 was $200 \mathrm{~mm}$ above the TAF. A level reading at 22:00 was $550 \mathrm{~mm}$; another at 22:35 was $590 \mathrm{~mm}$. About that time, reactor building radiation was detected, and drywell pressure readings of $600 \mathrm{kPa}$ were obtained but were considered possibly abnormal. Reactor vessel pressure at 02:45 on March 12 was $0.8 \mathrm{MPa}$, about the same as containment pressure, indicating RPV relief to the suppression pool or vessel leakage. It took until about 14:00 on March 12 to vent the containment pressure. With reduced containment and reactor vessel pressure, low pressure fresh water injection was able to be established at a low rate. A hydrogen explosion occurred in the reactor building at 15:36.

Several observations were made in the TEPCO report. During this period, there were several occurrences of erroneous or potentially misleading reactor vessel level and pressure indications. At 02:30 on March 12, reactor water level readings of $1300 \mathrm{~mm}$ TAF and $500 \mathrm{~mm}$ TAF were obtained.

The main body of the TEPCO report (Ref. 17) noted analysis results performed weeks after the accident that provided plots of measured vs. analysis results of reactor vessel pressure readings as shown in figures that follow. The figures show potential instrumentation problems such as missing data, apparent erratic performance, differences between redundant instruments measuring the same parameters, or instruments measuring the same parameters indicating diverging trends or conditions. The sparsity of measured RPV pressure readings until late on March 13 is noted in Fig. 15. Also noted is the difference in measured readings between channels A and B on March 14 of about 0.5 MPa.

The same TEPCO reference also compared calculated RPV water level measurements vs. actual water level measurements, as shown in Fig. 16. Here, note differences in the earlier availability of the Fuel Range A indication compared with the Fuel Range B indication. Also note that the Fuel Range A value is approximately 0.8 meters higher than Fuel Range B in the early part of March 12 and that the Fuel Range A reading is missing for about $36 \mathrm{~h}$ from March 12 to 14. TEPCO commented that consequences from core damage can cause water to evaporate from the condensing chambers in the drywell and cause erroneous water level readings. They discovered during calibration on May 11 that this was likely the case, and water levels measured after core damage were assumed to be unreliable. Pressure readings are subject to this same effect.

Fig. 17 shows actual vs calculated containment pressure for Unit 1 . There are significant periods when there were no measured values. Drywell and suppression pool (i.e., suppression chamber) pressure indications track with a small offset to account for water pressure in the suppression pool, which is expected.

Because of the station power loss, there was no electrical power to support accident monitoring instrumentation, including containment radiation monitoring, building and site radiation monitoring, meteorological instrumentation, etc. Leakage from the drywell and/or suppression pool to the reactor building and leakage from the reactor building explosion were not measured. 


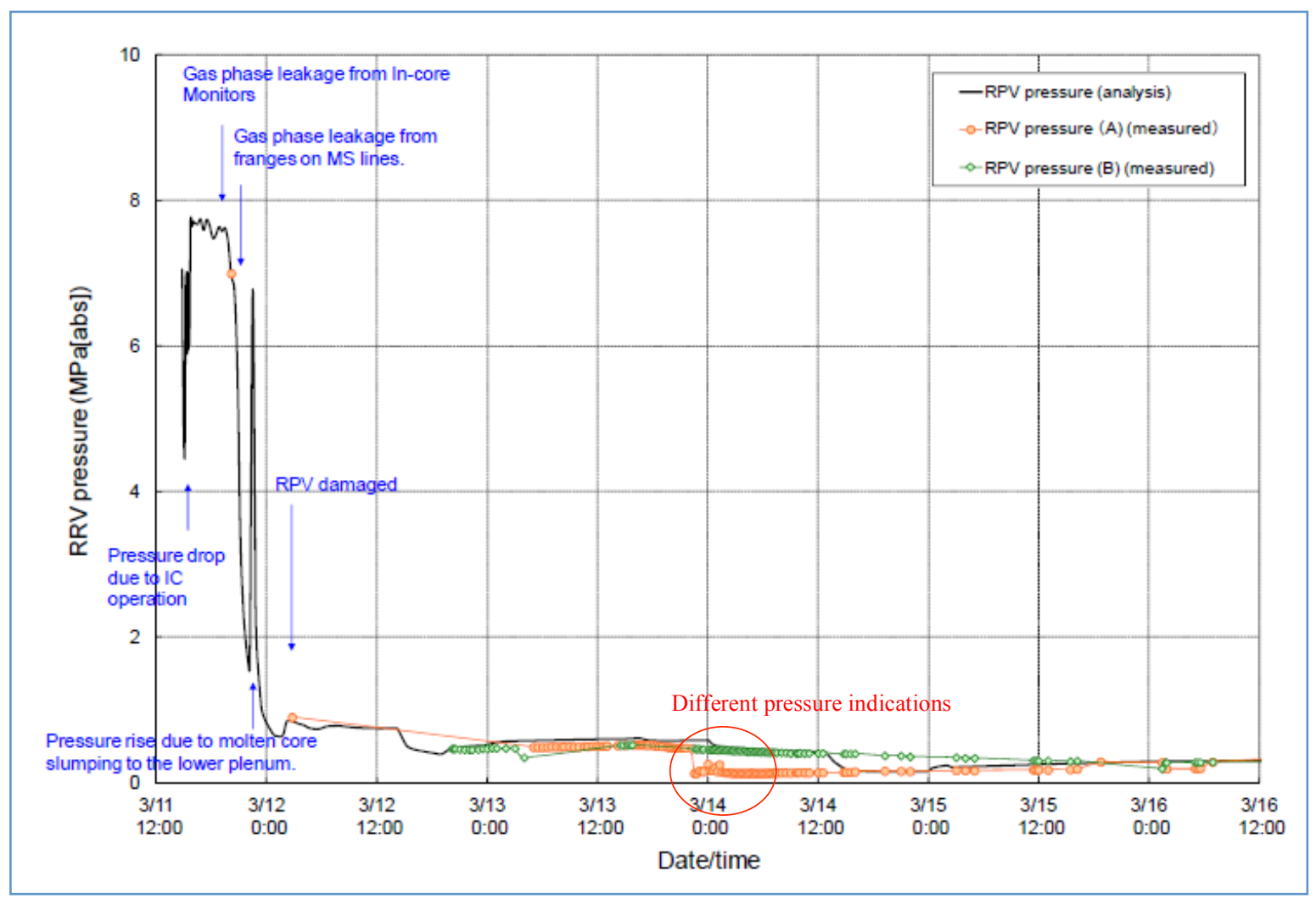

Fig. 15. Actual vs calculated RPV pressure-Unit 1.

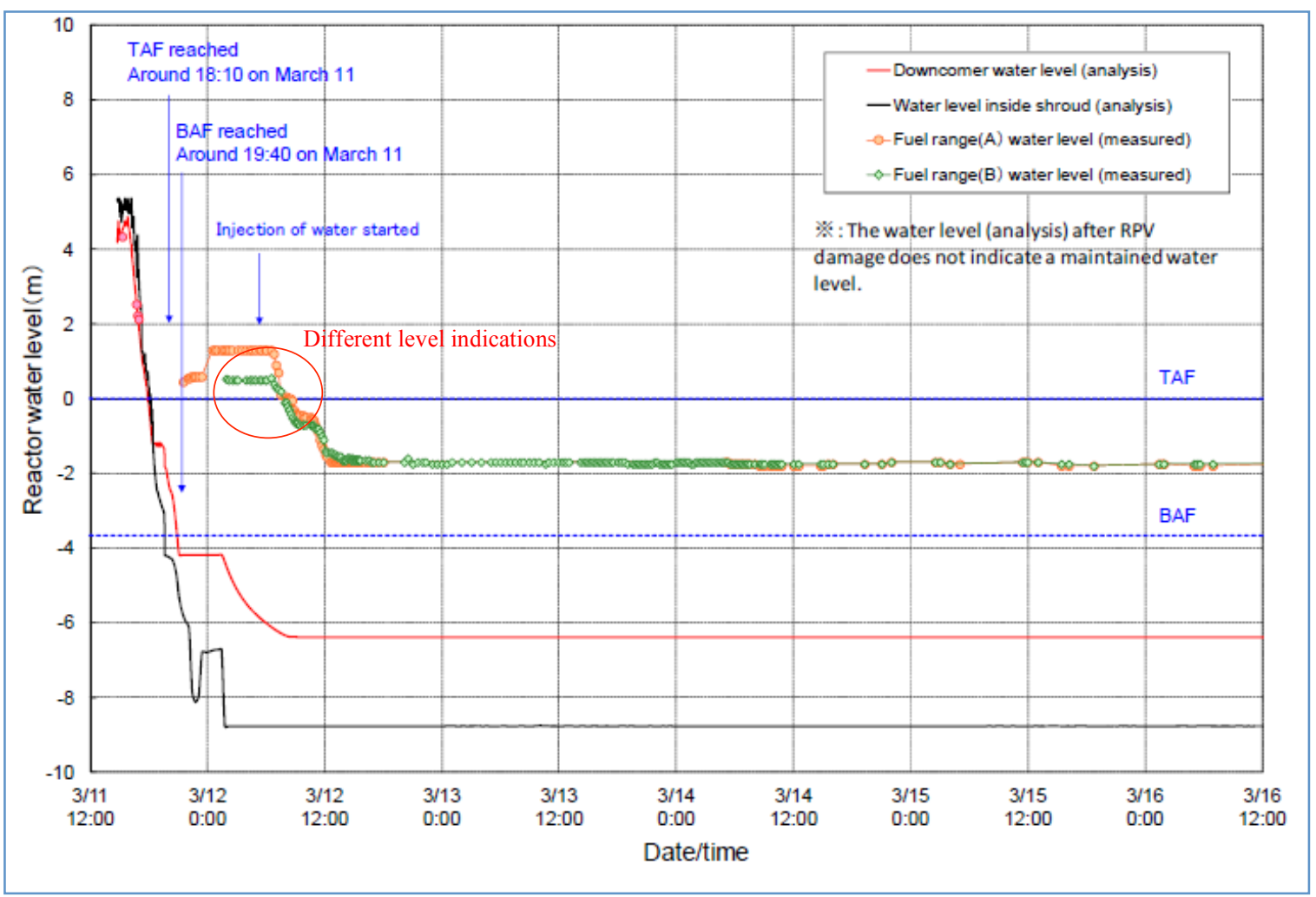

Fig. 16. Actual vs calculated RPV level-Unit 1. 


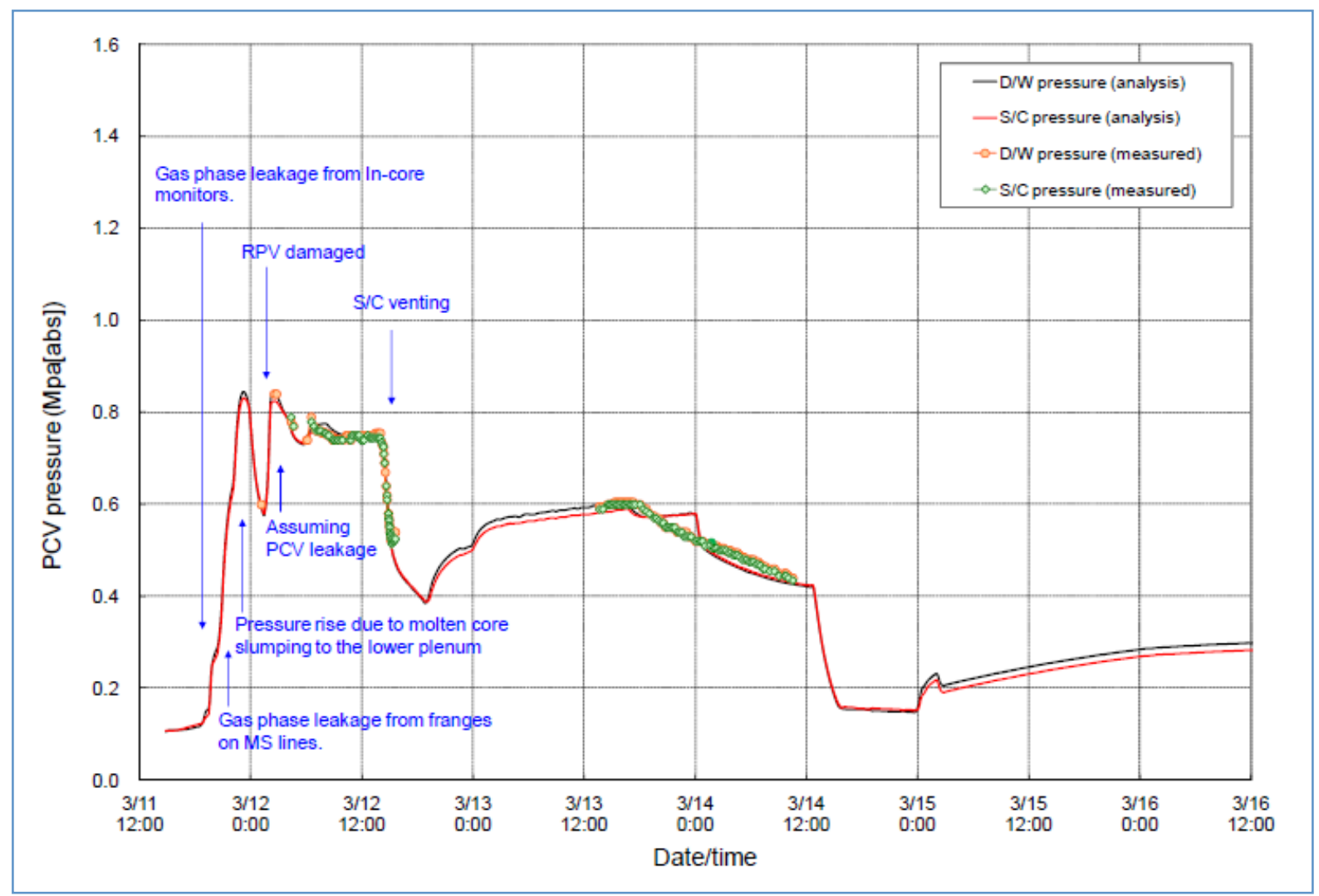

Fig. 17. Actual vs calculated containment pressure-Unit 1.

\section{Unit 2}

As the tsunami waves began to hit the site, RCIC was manually started at 15:39. Minutes later, Unit 2 lost operating equipment and monitoring instrumentation as a result of the loss of all ac and dc electrical power. RCIC status could not be confirmed until 21:02. HPCI was not operable as a result of the loss of dc control power. A small generator was used to restore control room lighting, and the RPV water level was shown to be 3,400 mm TAF. Reactor and containment pressure indication was restored shortly after 21:02. At 02:55 on March 12, operators were able to determine that RCIC was working based on pump discharge pressure and declining condensate storage tank level (the condensate storage tank is the primary water source for RCIC). Operators switched the RCIC suction source to the suppression pool. At approximately 17:20 on March 12, drywell pressure was 200$300 \mathrm{kPa}$. Operators were performing tasks and obtaining instrument readings in the reactor building. RCIC operation ceased operation mid-day on March 14. TEPCO noted a RCIC trip on the high RPV level should have occurred but did not because of the lack of control power. Two-phase flow to the RCIC turbine was later concluded, resulting in reduced RCIC flow rate but still providing a reactor pressure relief path from the RCIC steam line through the turbine to the suppression pool. That the RCIC continued operation for this length of time was not expected. RPV depressurization using safety relief valves powered by scavenged car batteries began at 17:17 on March 14 in preparation for seawater injection. A loud sound and vibrations occurred at 06:14 on March 15; operators believed this was the sudden failure of secondary containment based on the secondary containment pressure indication dropping to $0 \mathrm{kPa}$; however, drywell pressure remained at $730 \mathrm{kPa}$.

Fig. 18 shows actual vs. calculated RPV pressure readings for Fukushima Unit 2 shown in the main body of the TEPCO report. TEPCO noted an erroneous indication associated with battery performance. 


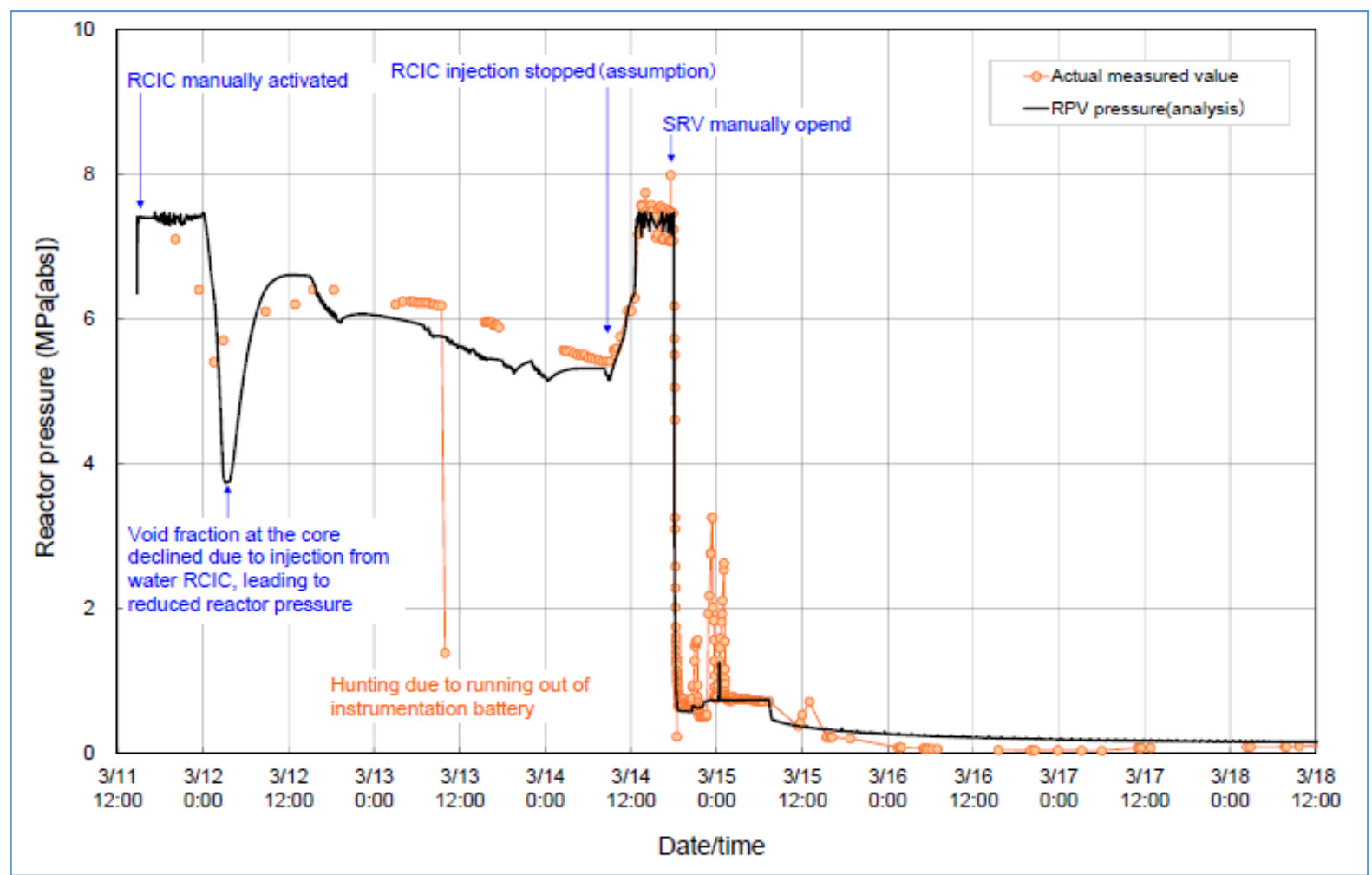

Fig. 18. Actual vs. calculated RPV pressure-Unit 2.

Fig. 19 shows actual vs. calculated RPV water level indications shown in the main body of the TEPCO report. Differences between the calculated and actual values are based on a calibration by atmospheric pressure and saturation temperature. It was corrected at a later time using reactor pressure and drywell temperature. Thus, the original measured values were incorrect.

Fig. 20 shows actual vs. calculated containment pressure indications. This figure shows significant differences between the drywell and secondary containment actual measured values, which could potentially mislead or confuse operators in the midst of emergency actions. Both the drywell and secondary containment pressure indications are erratic, erroneous, and missing for significant portions from mid-day on March 14 through March 18.

As a result of the station power loss, there was no electrical power to support accident monitoring instrumentation, including containment radiation monitoring, building and site radiation monitoring, meteorological instrumentation, etc. Leakage from the drywell and/or suppression pool to the reactor building and the leakage from the reactor building explosion were not measured. 


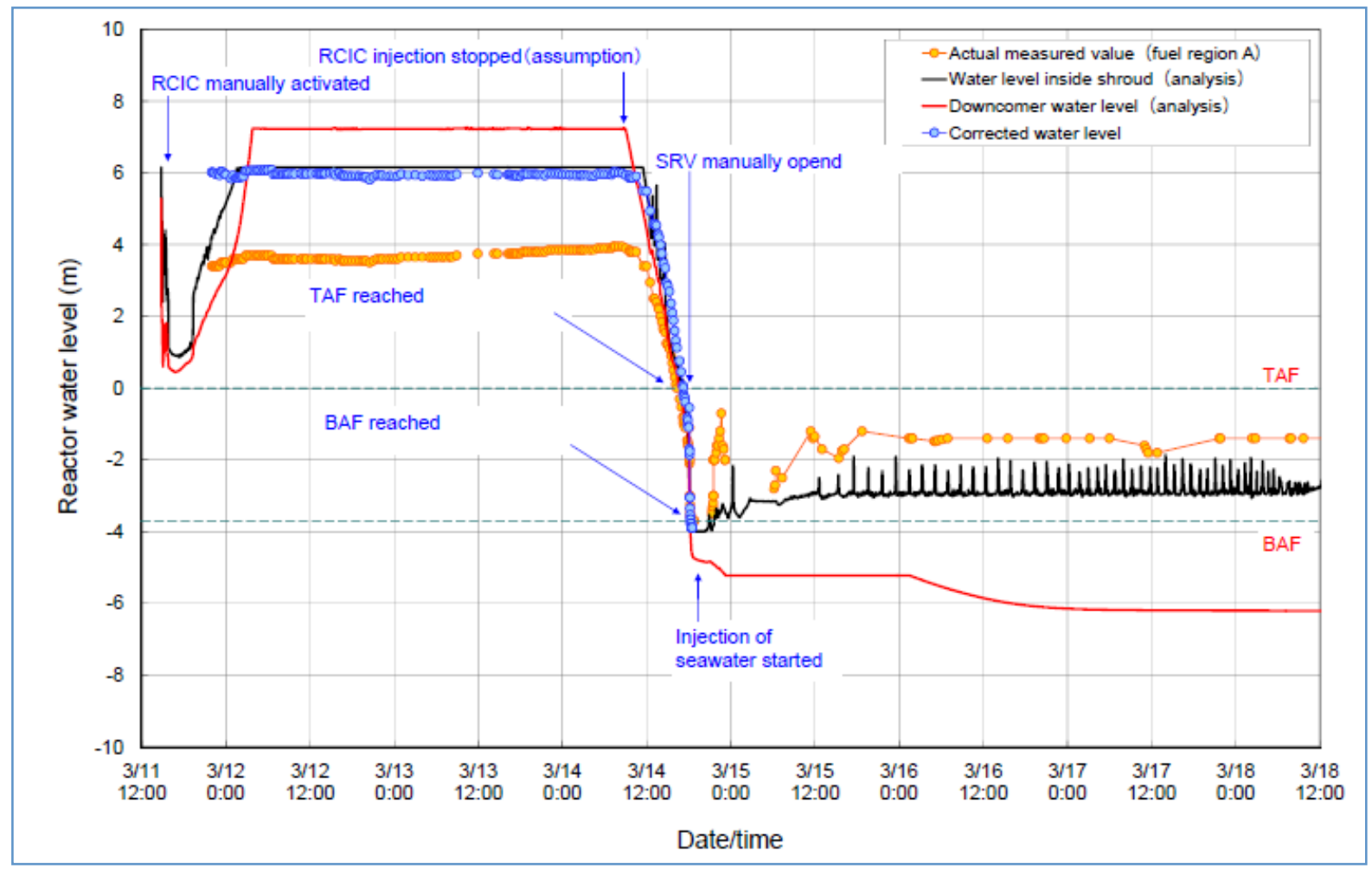

Fig. 19. Actual vs. calculated RPV water level-Unit 2.

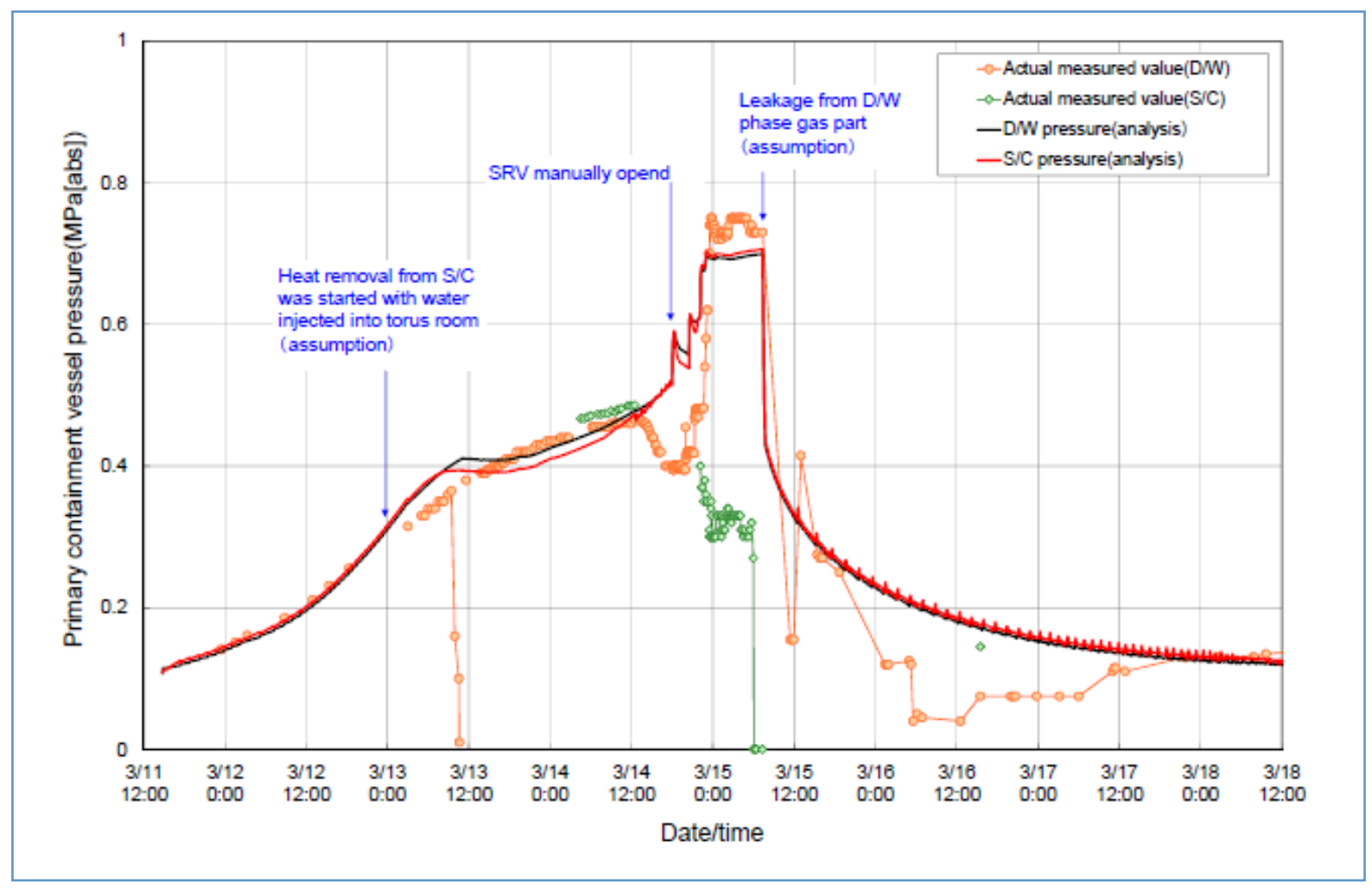

Fig. 20. Actual vs. calculated containment pressure-Unit 2. 


\section{Unit 3}

The tsunami waves knocked out emergency ac electrical power to Unit 3; however, dc electrical power supplied through batteries was not lost. Control room indication of reactor conditions was retained as was control power for RCIC and HPCI. As reported by TEPCO, the RCIC system was manually started at 16:03 on March 11 and ran for about $20 \mathrm{~h}$ before shutting down automatically because of low reactor water level. An hour later, HPCI started automatically. Both RCIC and HPCI were controlled manually in an attempt to prevent automatic shutdown. About $24 \mathrm{~h}$ after the tsunami, reactor level monitoring was lost because of battery depletion. It was restored by replacement batteries about $8 \mathrm{~h}$ later. HPCI was manually shut down around 02:00 on March 13, after running for approximately $14 \mathrm{~h}$, because of nearly equal reactor pressure and HPCI pump discharge pressure, meaning the system was providing little flow. Reactor pressure subsequently increased; however, HPCI could not be restarted because of a dead battery, and RCIC could not be restarted because of valve problems. Operators assembled batteries to depressurize the RPV via safety relief valves at 09:08 on March 13, which allowed some low-pressure water injection to occur. A drywell pressure drop occurred at about the same time, but the containment venting could not be sustained.

Containment pressure rose again. A hydrogen explosion occurred in the reactor building at 11:01 on March 14.

Fig. 21 shows actual vs. calculated RPV water level indications as shown in the main body of the TEPCO report. Given that Unit 3 had dc electrical power following the tsunami until the batteries were exhausted, there are RPV water level indications for about $24 \mathrm{~h}$. Then there is a period of approximately $24 \mathrm{~h}$ beginning about 14:00 on March 12 with sparse water level readings, possibly due to depleted batteries. Water level readings around 06:00 on March 13 that differ significantly from calculated readings are not explained.

Actual RPV pressure readings shown in Fig. 22 appear to be reasonable and match calculated values. The circled area illustrates the differences in the steam usage and subsequent pressure drop of the HPCI compared with the RCIC system.

Actual containment pressure readings shown in Fig. 23, taken from the main body of the TEPCO report, show reasonable agreement between the drywell and suppression pool pressure readings for March 13 and 14. Readings in the March 17 time period, when the actual suppression pool readings are anomalous, were not explained (and were not the point of the figure in the TEPCO report). There are significant amounts of missing suppression pool data.

As a result of the station power loss, there was no electrical power to support accident monitoring instrumentation, including containment radiation monitoring, building and site radiation monitoring, meteorological instrumentation, etc. Leakage from the drywell and/or suppression pool to the reactor building and the leakage from the reactor building explosion were not measured. 


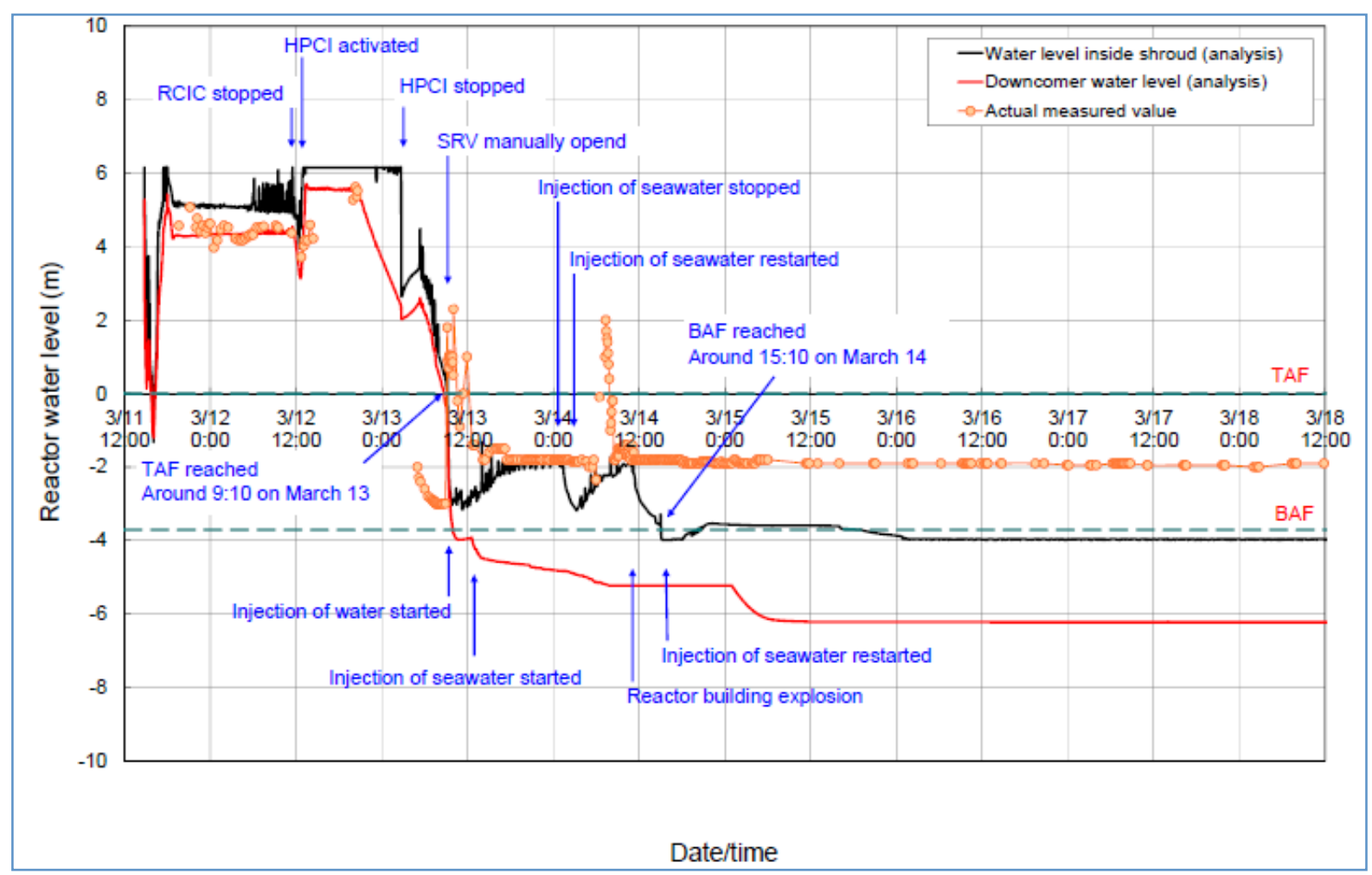

Fig. 21. Actual vs. calculated RPV water level-Unit 3.

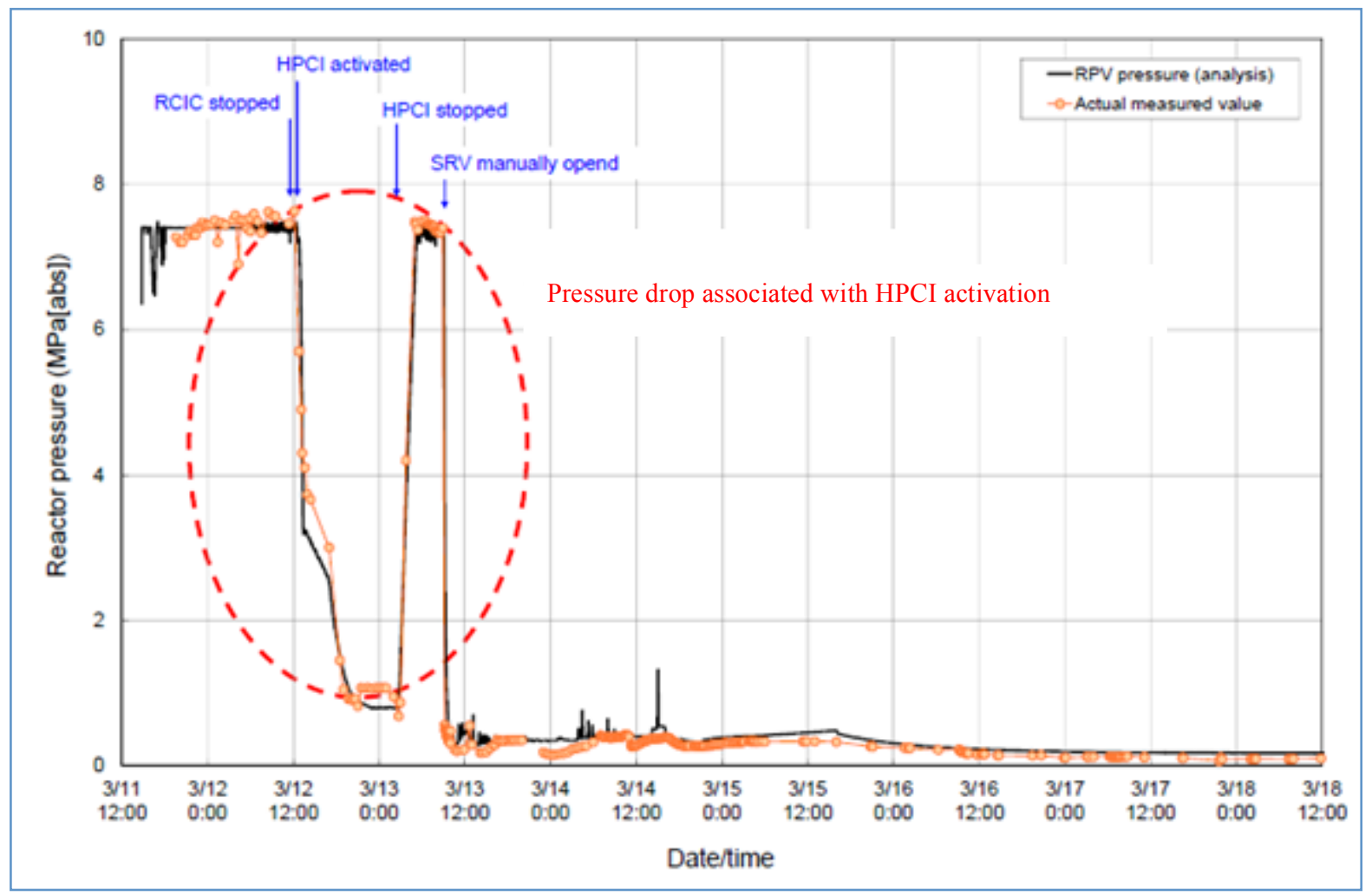

Fig. 22. Actual vs. calculated RPV pressure-Unit 3. 


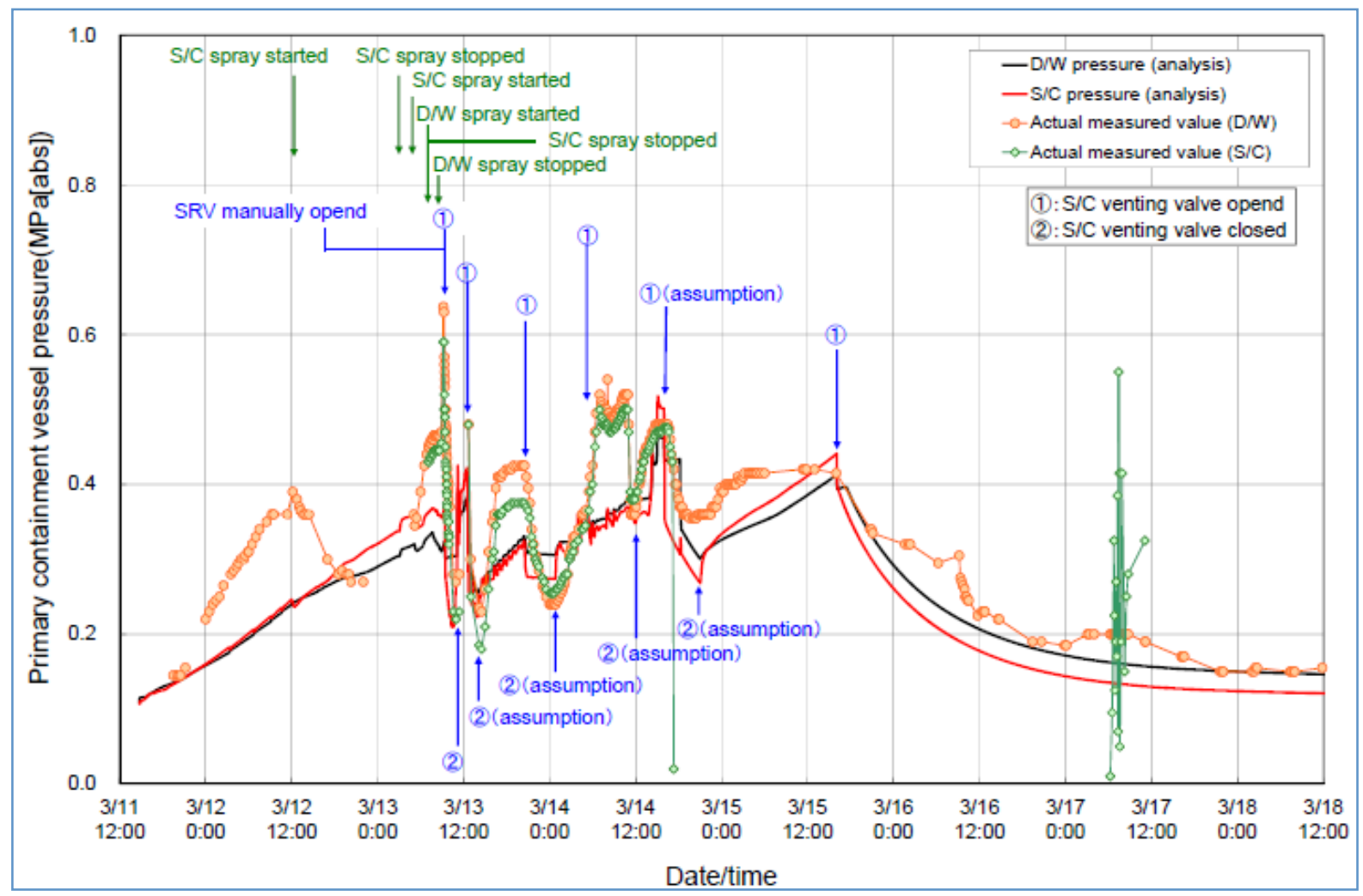

Fig. 23. Actual vs. calculated containment pressure-Unit 3.

\subsubsection{Time Period: Post-Reactor Building Explosions until the end of March 2011}

Operators were able to begin injecting cooling water from diesel-driven pumps, and later from electric pumps, into the reactor cores of Units 1-3 once pressures in the reactor vessels and containments were reduced to below the pressure limits of these pumps. Conditions in the damaged units became more stable regarding cooling of the core materials whether located in the reactor vessels or in the drywells. Alternate power sources were connected to control rooms, and some instrumentation was restored.

Data compiled by TEPCO during its accident response were compiled and ultimately provided on its website (Ref. 31). This data was used to cover a more extended time period through the end of March than was provided in the prior TEPCO figures. Figures compiled during that period illustrate instrument performance for Fukushima Units 1-3 for several important parameters: RPV pressure, RPV level, drywell pressure, suppression pool pressure, and radiation readings from the drywell and suppression pool.

\section{Unit 1}

Residual heat removal pressure readings compiled by TEPCO for Unit 1 (shown in Fig. 24) show interesting differences during March 13-16. The data for Channel B early on is divergent from Channel A data from March 14 through March 16 and then tracks reasonably well. On March 26, the two channels diverge again. The cause for the divergent readings is not clear.

RHR water level readings for Unit 1 shown in Fig. 25 show reasonable similarity. Drywell and suppression pool pressure readings for Unit 1 shown in Fig. 26. Drywell and suppression pool pressure-Unit 1.show consistent readings. Gaps in the readings were not explained. 


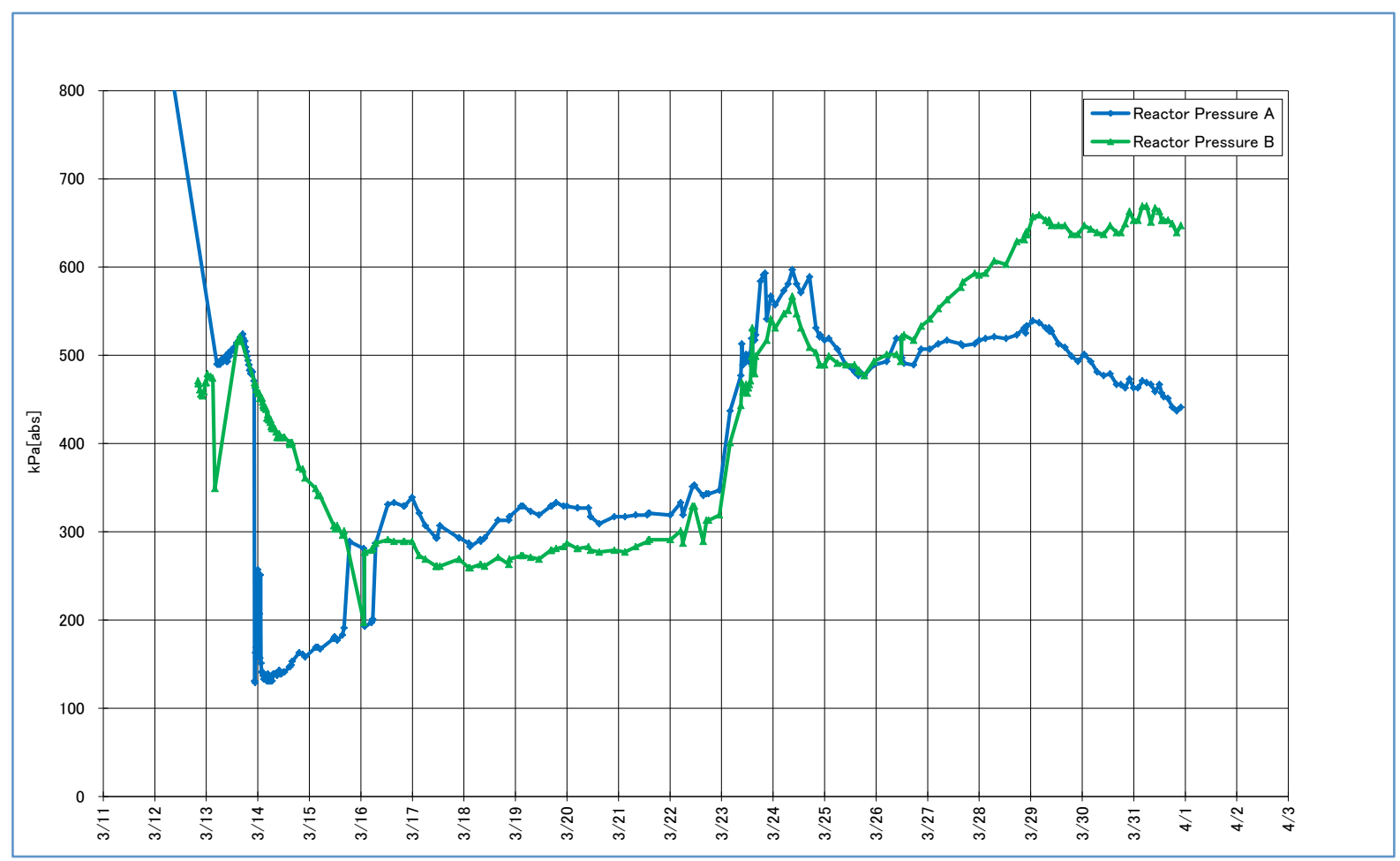

Fig. 24. RPV pressure-Unit 1.

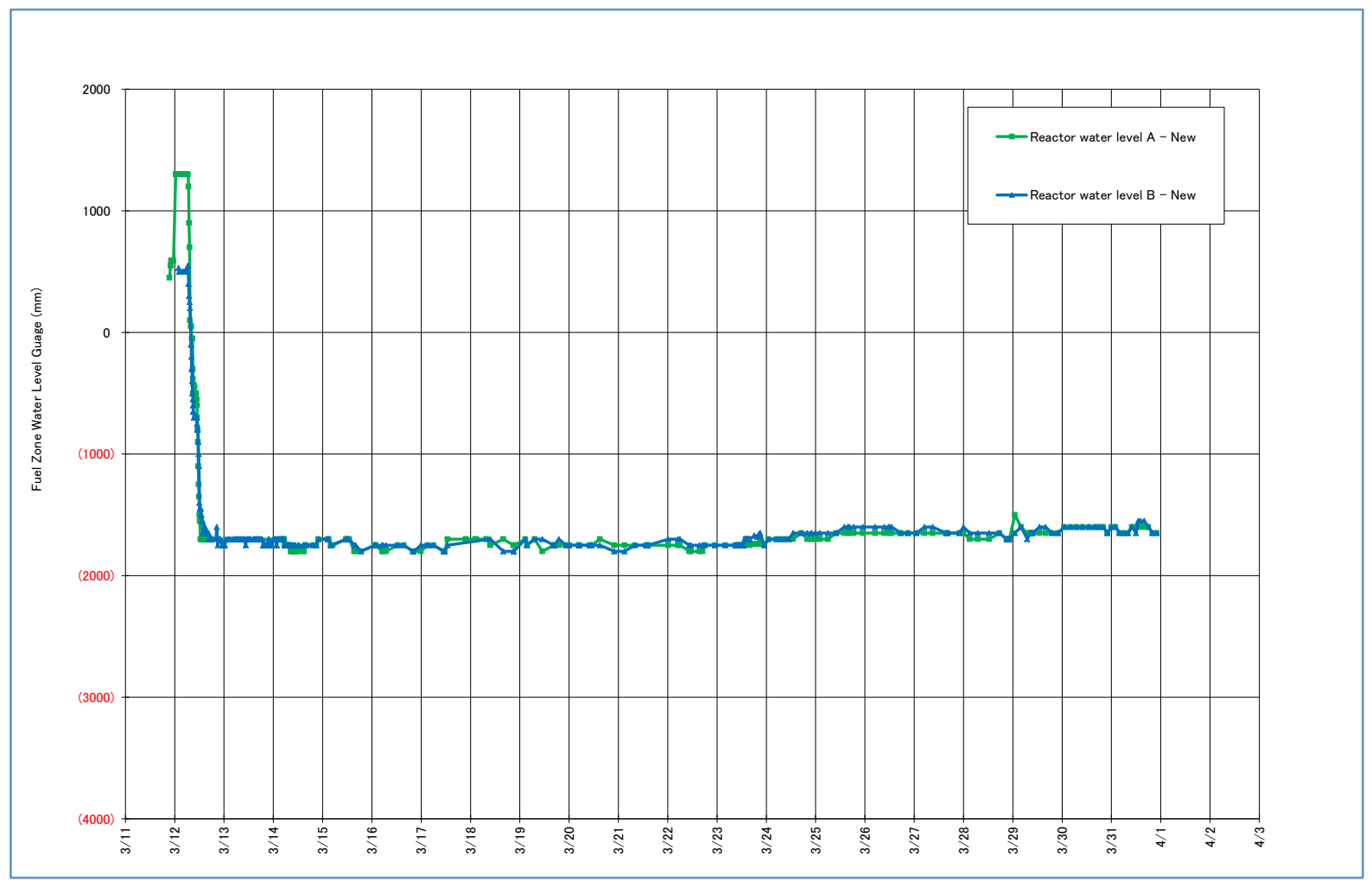

Fig. 25. RPV water level-Unit 1. 
Drywell and suppression pool radiation readings for Unit 1 are shown in Fig. 27. Drywell radiation readings from Channel A appear erratic in the March 14-16 time frame and then are no longer available. Channel B readings appear erratic until approximately March 21. The suppression pool radiation readings from Channel A are present in the March 14-16 time frame and then are no longer available. Suppression pool radiation readings from Channel B are missing or appear erratic until about March 18. A number of dropouts are observed for drywell and suppression pool readings on March 21 and March 29.

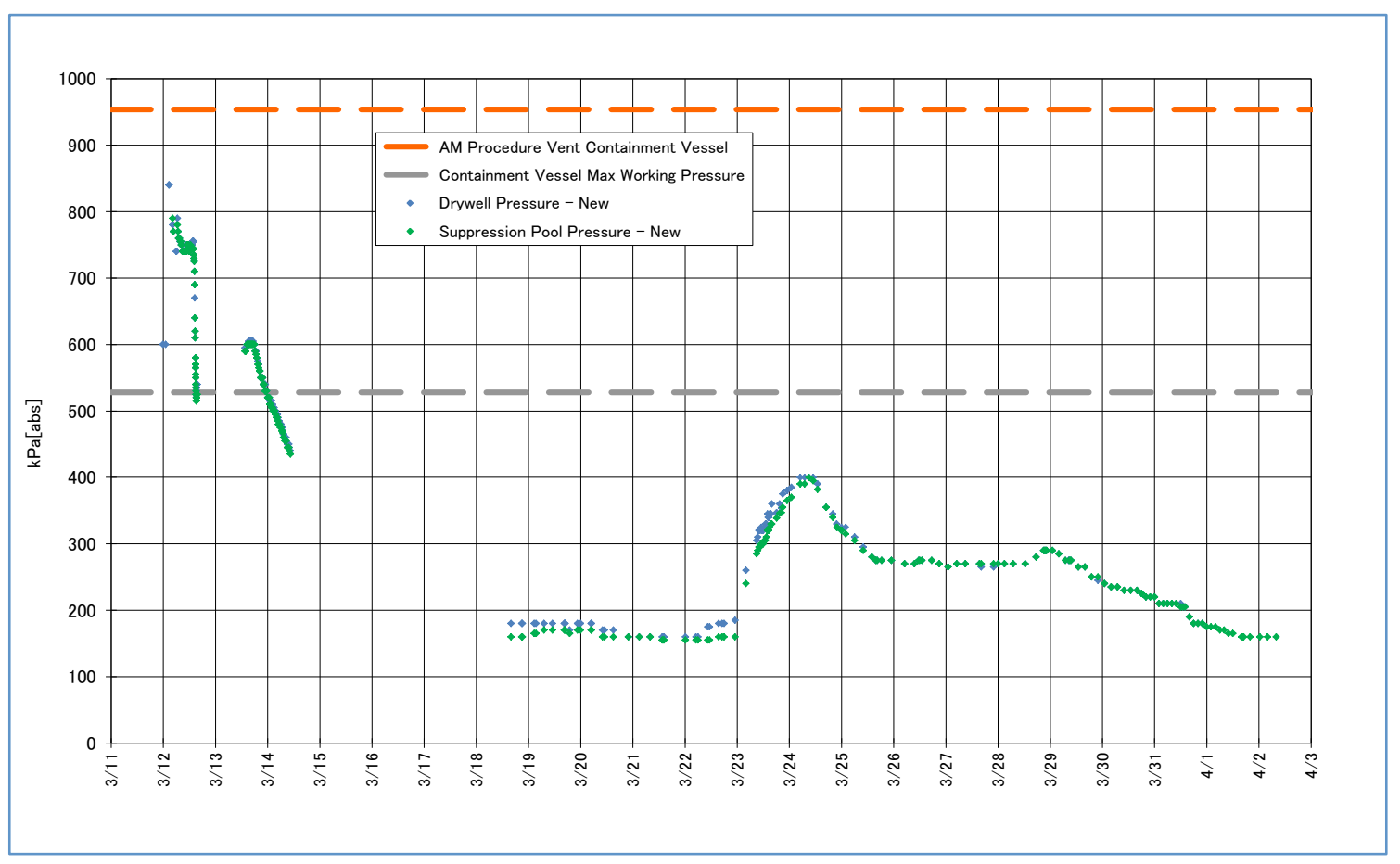

Fig. 26. Drywell and suppression pool pressure-Unit 1. 


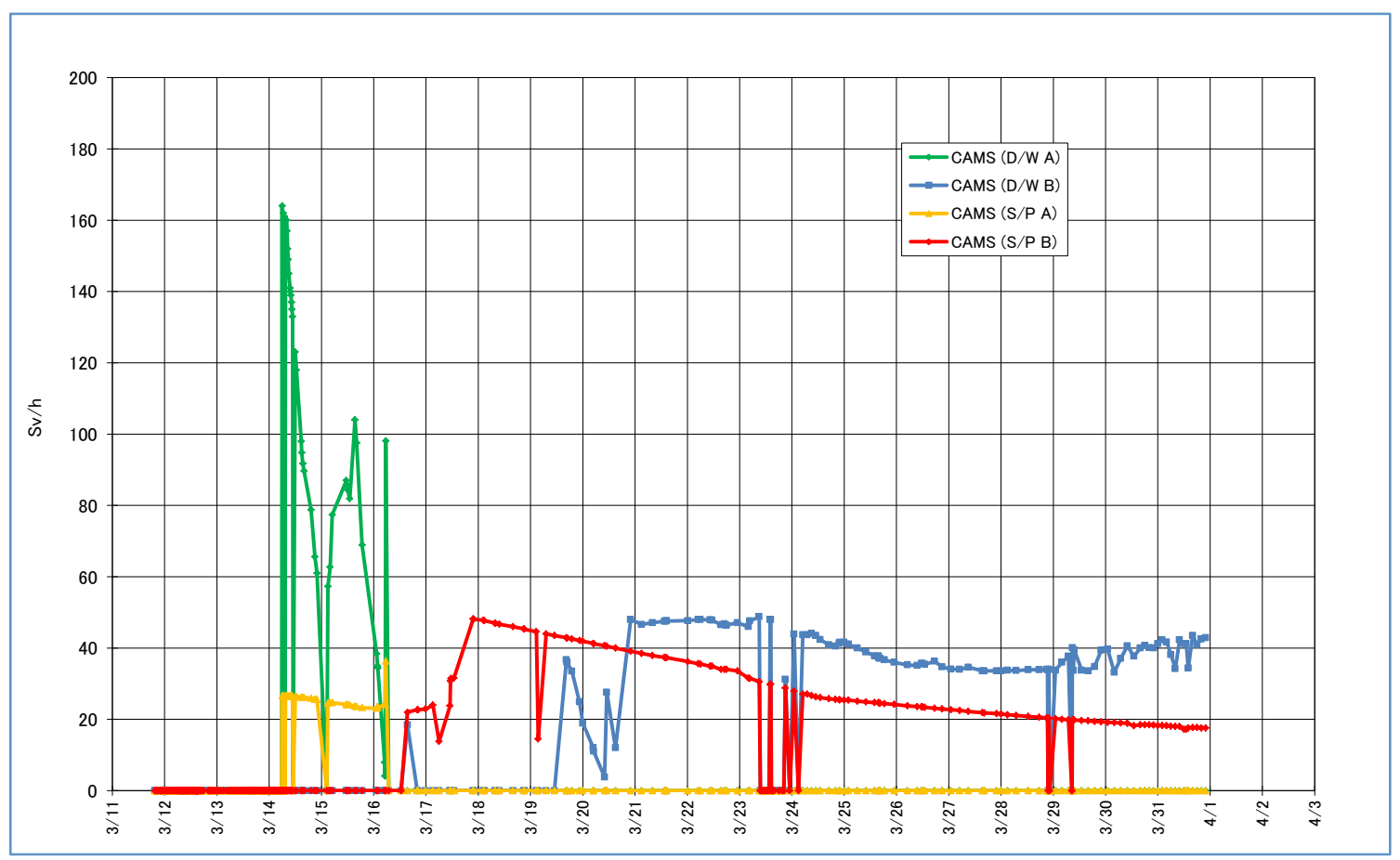

Fig. 27. Drywell and suppression pool radiation-Unit 1.

\section{Unit 2}

RHR pressure readings compiled by TEPCO for Unit 2 shown in Fig. 28 are similar readings except at the start of the chart. The reason for the missing readings from Channel $\mathrm{B}$ is not known.

RHR water level readings for Unit 2 in Fig. 29 show missing data for Channel B, and differing data once data is available. The cause for this is not known.

Drywell and suppression pool pressure readings for Unit 2 in Fig. 30 show a fairly complete set of data for the drywell pressure but an incomplete and differing set of data for suppression pool pressure.

Drywell and suppression pool radiation readings for Unit 2 are shown in Fig. 31. A negative spike is apparent around March 16 and March 20 for the drywell radiation reading. The suppression pool readings are notable for their unexpectedly low levels. The cause for this is not known. 


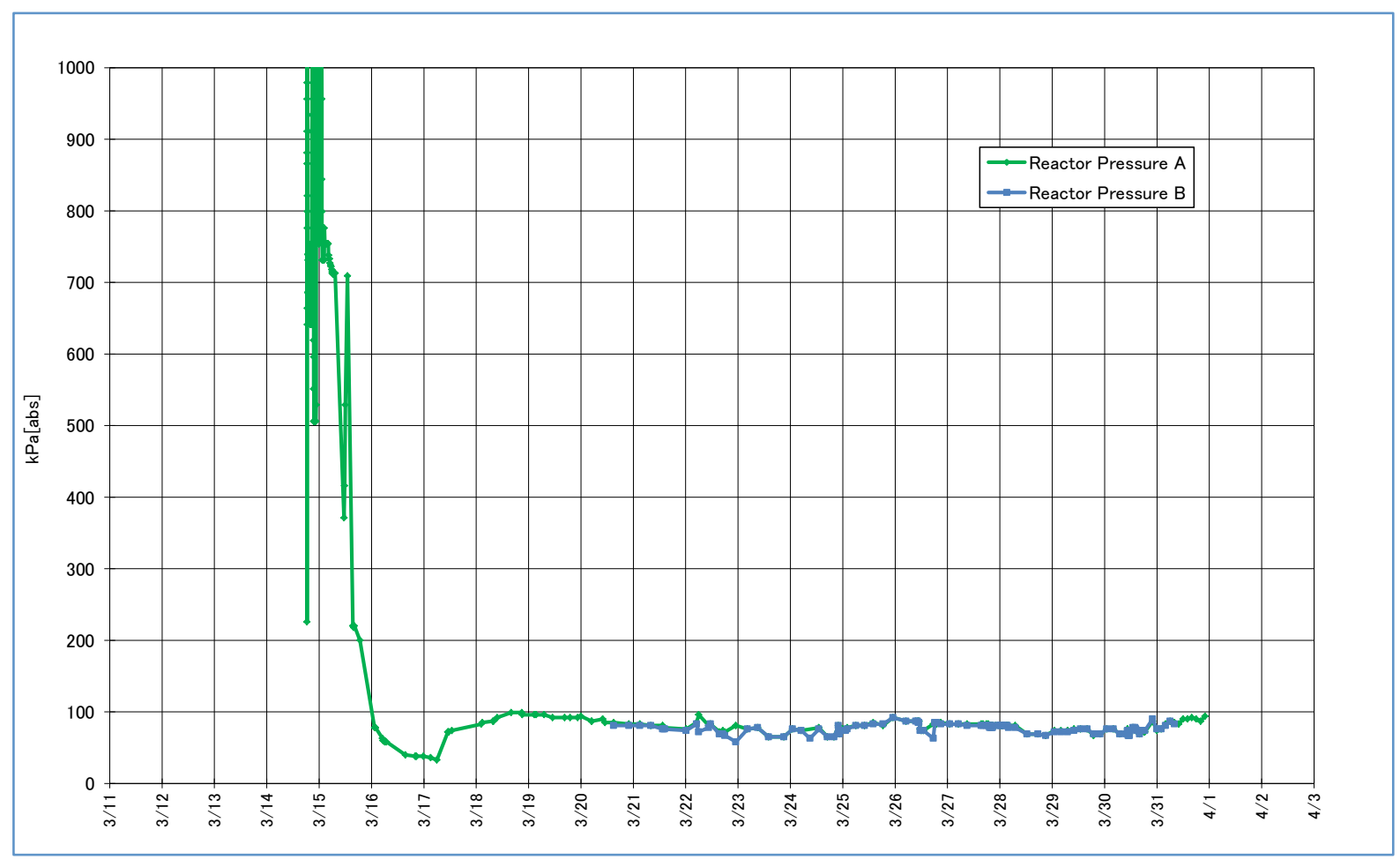

Fig. 28. RPV pressure-Unit 2.

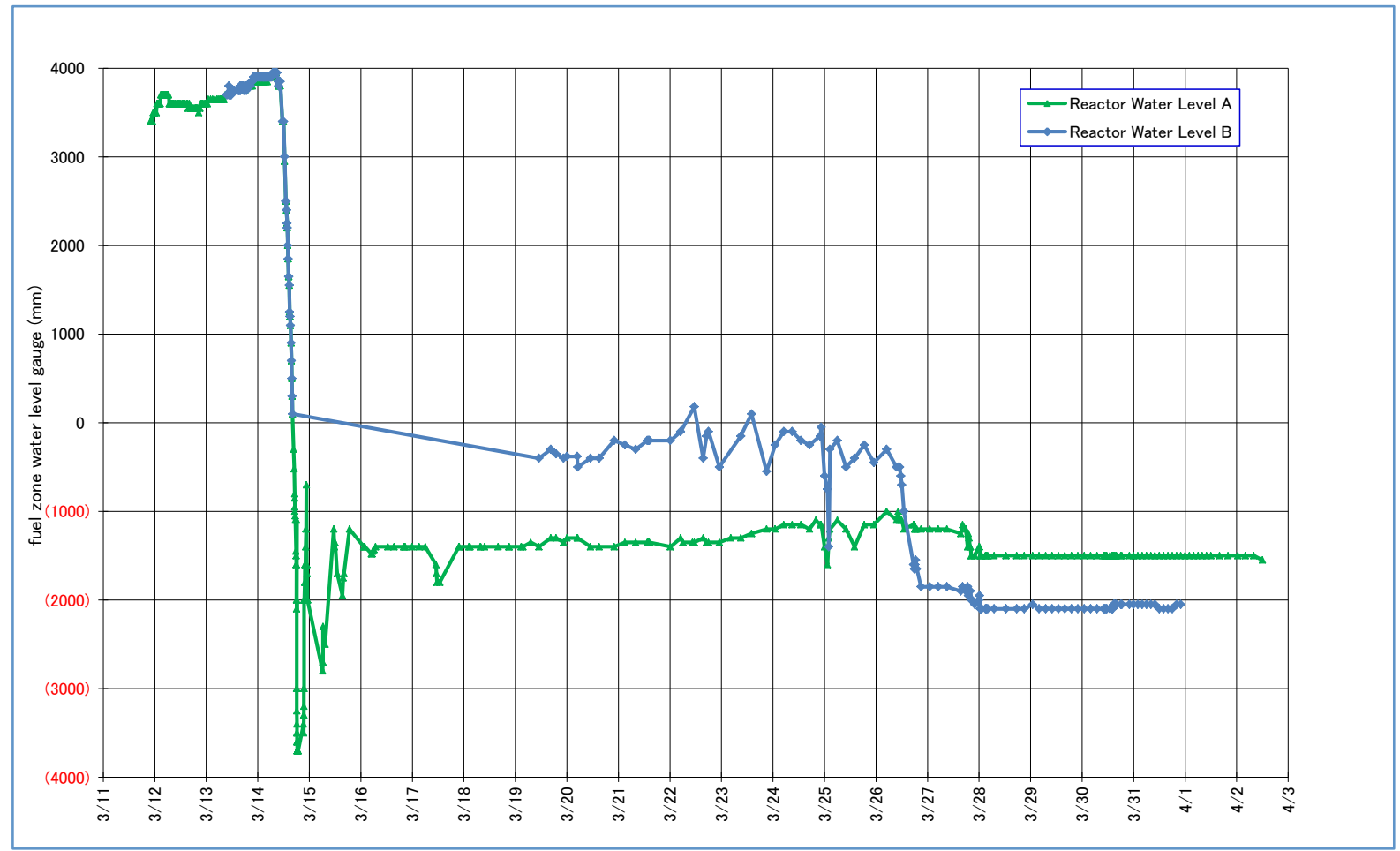

Fig. 29. RPV water level-Unit 2. 


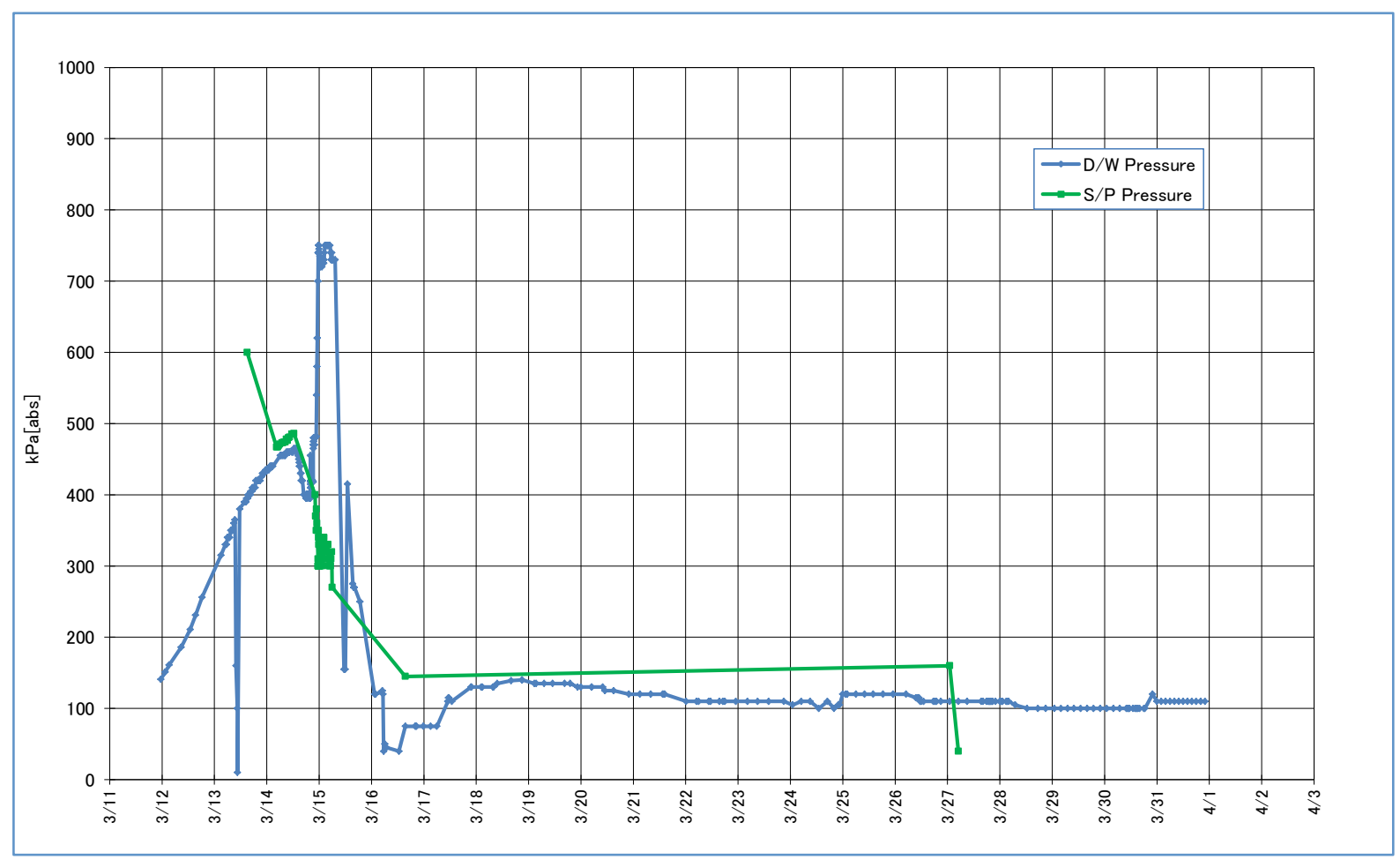

Fig. 30. Drywell and suppression pool pressure-Unit 2.

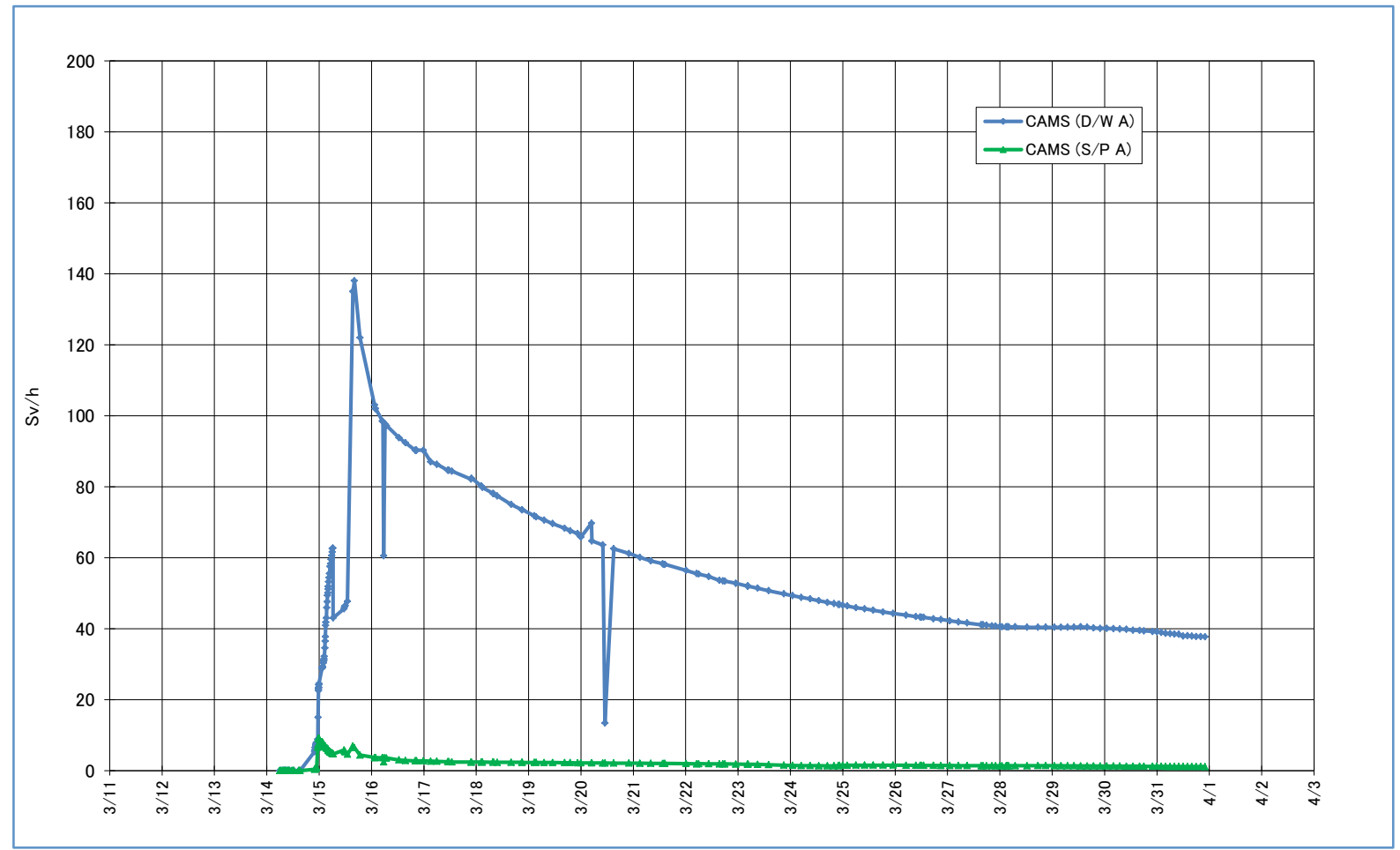

Fig. 31. Containment radiation-Unit 2. 


\section{Unit 3}

RHR pressure readings compiled by TEPCO for Unit 3 in Fig. 32 spike for Channel A and then show differences between channels A and B from March 21 on. The causes of the differences are not known.

RHR water level readings for Unit 3 in Fig. 33 show similar trends, but an offset of about $400 \mathrm{~mm}$ is present through much of the chart. The cause is not known.

Drywell and suppression pool pressure readings for Unit 3 in Fig. 34 show a fairly complete set of data for the drywell pressure but an incomplete and somewhat erratic set of data for suppression pool pressure. The reason is not known.

Drywell and suppression pool radiation readings for Unit 3 are shown in Fig. 35. Drywell Channel B readings are missing early on. Drywell Channels A and B then track reasonably until the end of March. The suppression pool radiation channels correlate with each other but not with accident conditions. The reason is not known.

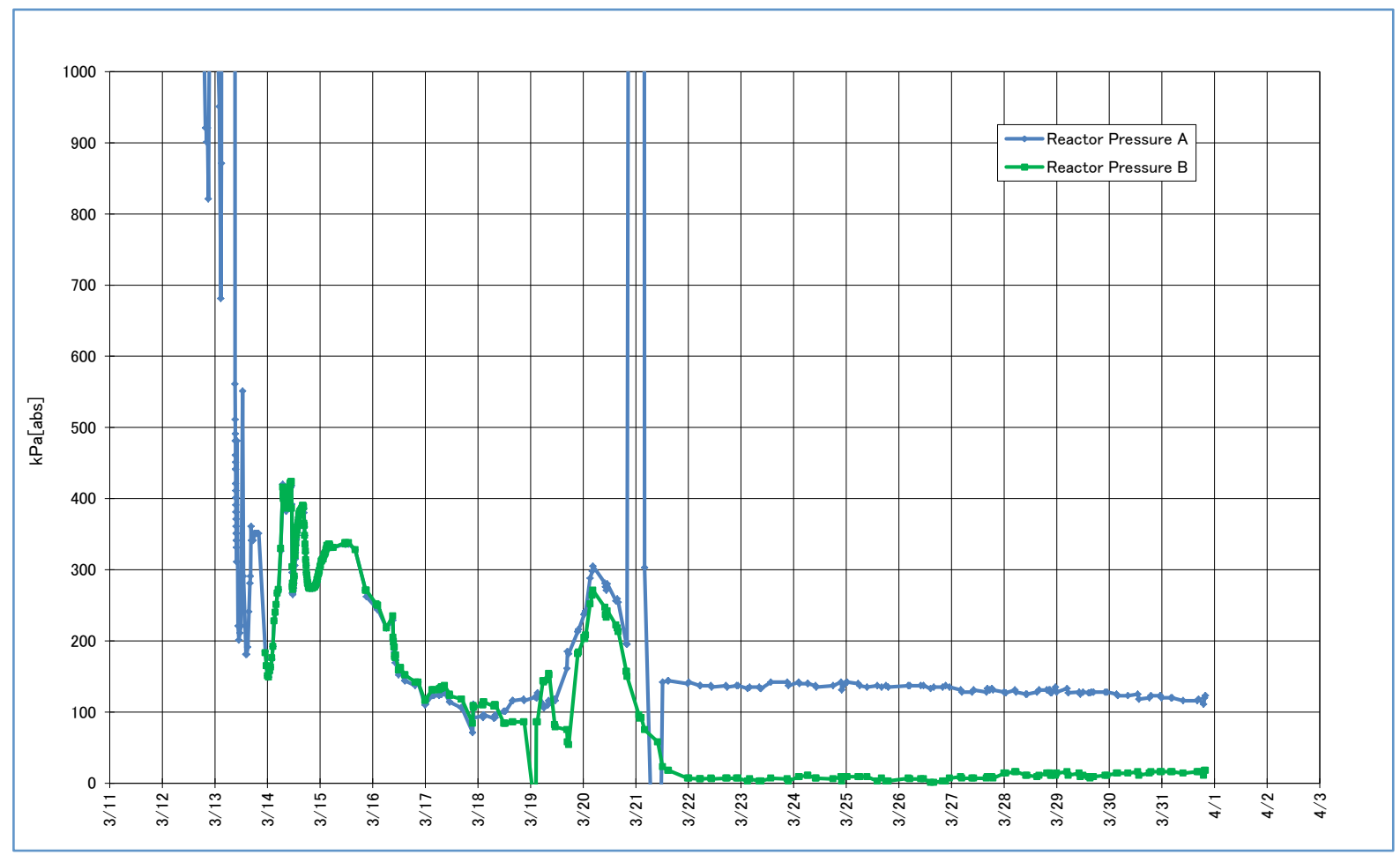

Fig. 32. RPV pressure-Unit 3. 


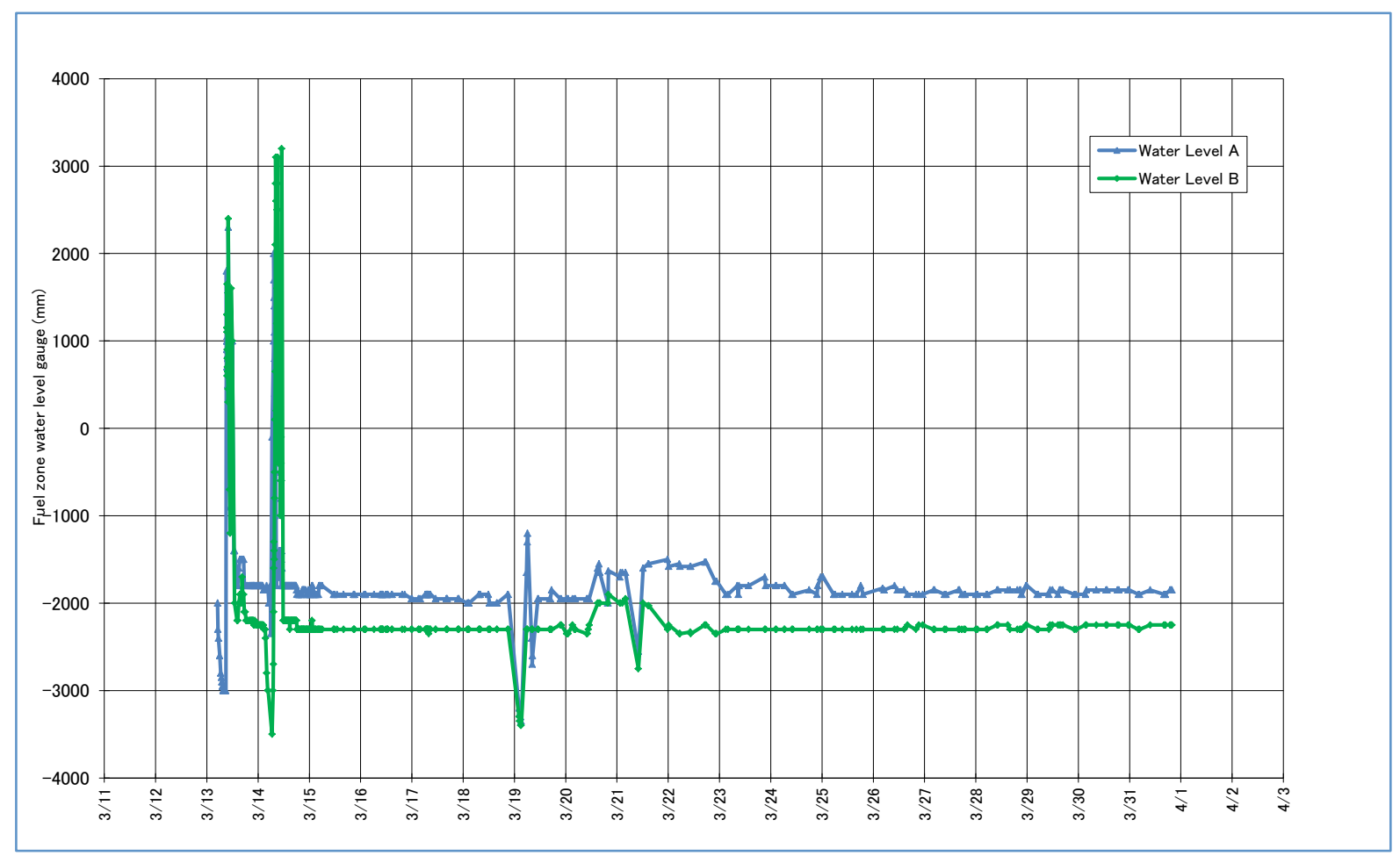

Fig. 33. Reactor water level-Unit 3.

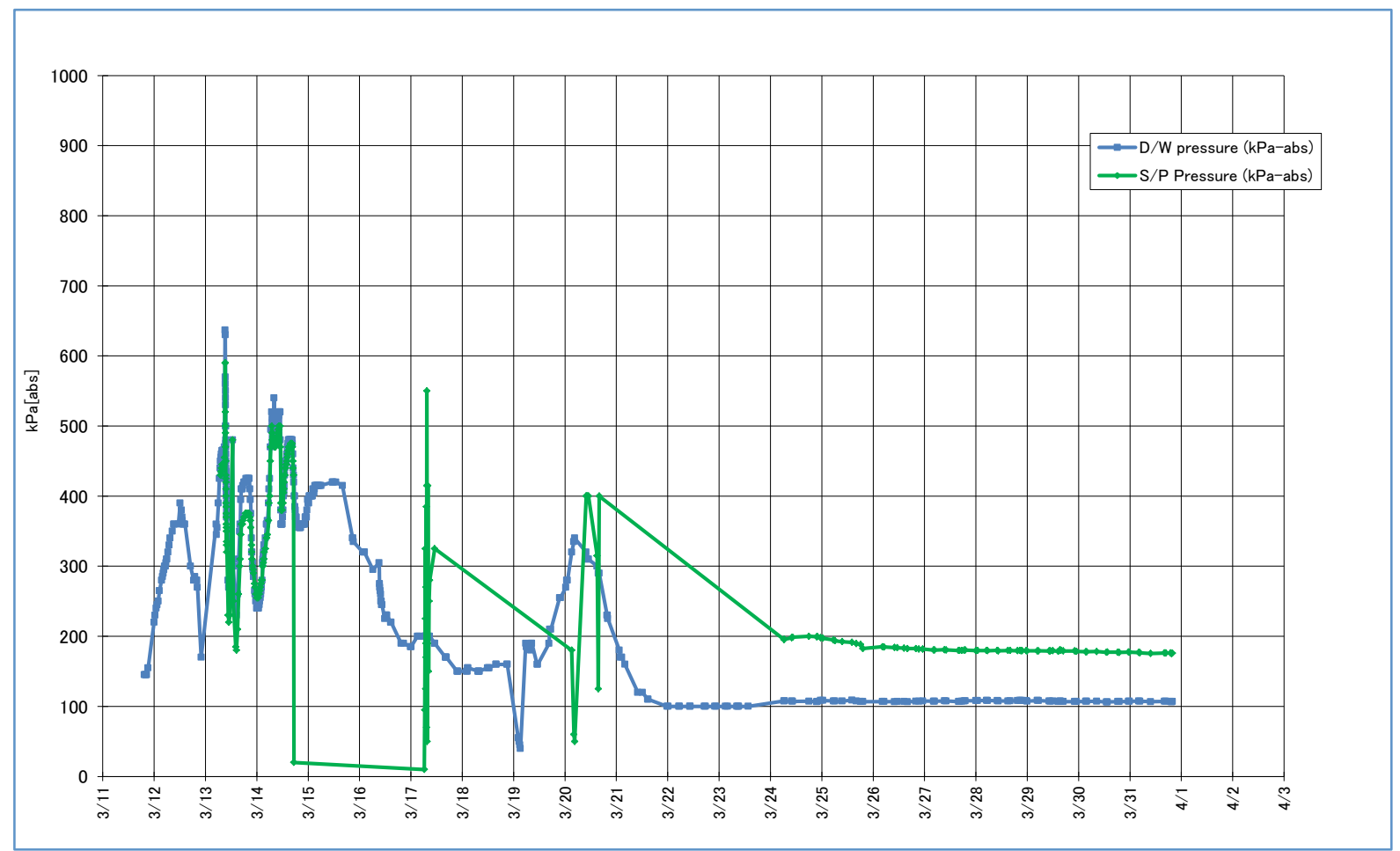

Fig. 34. Drywell and suppression pool pressure-Unit 3. 


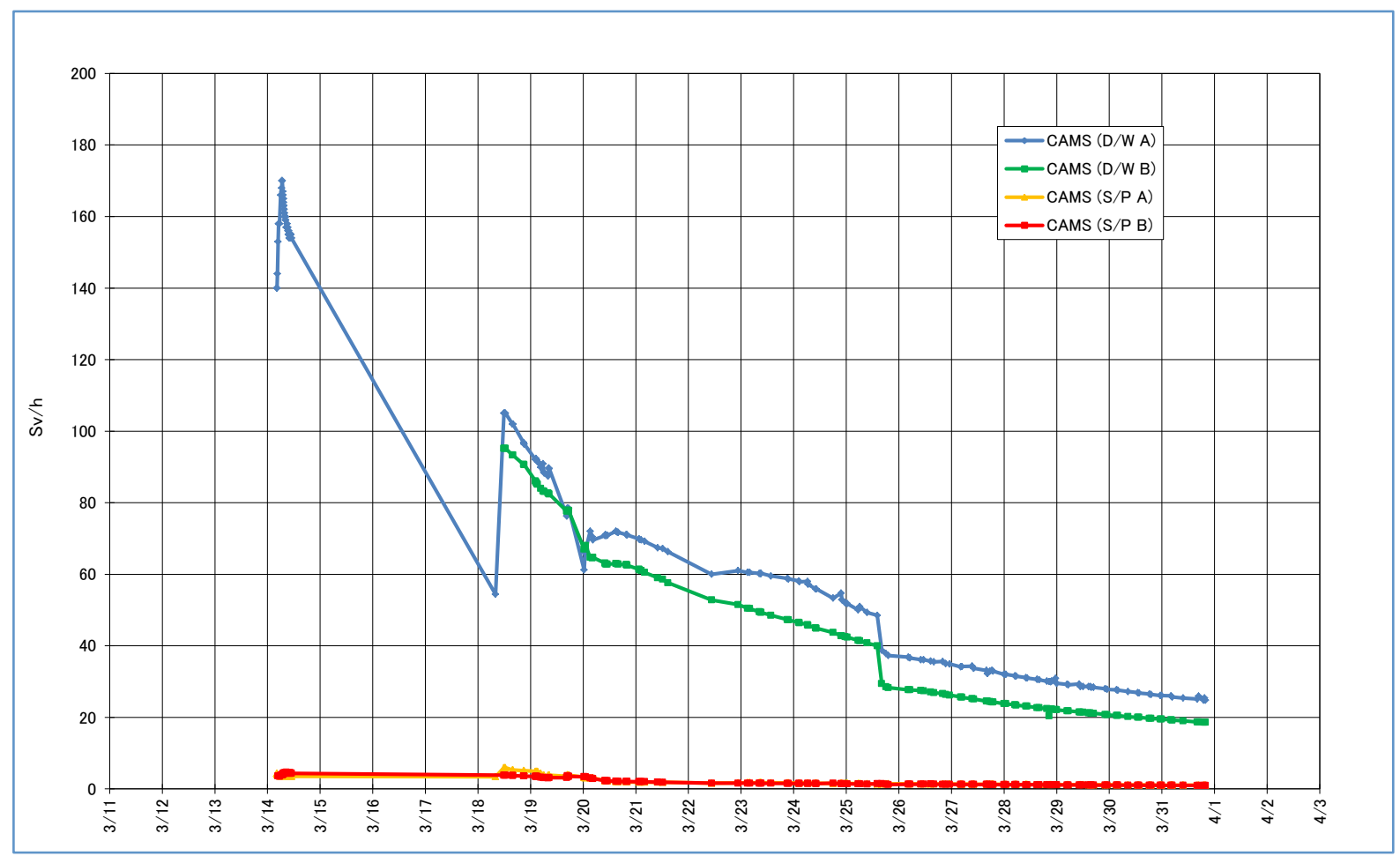

Fig. 35. Containment radiation-Unit 3.

\subsection{INSTRUMENTATION AND CONTROL SYSTEM PERFORMANCE/FAILURE ASSESSMENT}

The references for the descriptions and analyses of the Fukushima Daiichi accident primarily addressed the major sequences of events leading to the core damage and radiation releases. References to the performance of instrumentation after the tsunami were generally limited to key BWR parameters of reactor vessel level and pressure, drywell pressure, and suppression pool pressure. Understandably, attention to other plant instrumentation systems, even accident management systems, was limited as operator attention was centered on core cooling and protection of containment and power restoration directly associated with these functions.

Observations of instrument performance associated with key parameters of RPV level and pressure, drywell pressure, and suppression pool pressure are shown in Table 3. Missing data was a frequent observation due to difficulty in obtaining readings manually from local instrument racks and challenges in restoring instrument power for control room indicators. Other problems were associated with instrument calibration since reference columns and electronics for level and pressure readings were affected or potentially affected by the harsh environments where they were located. These issues could be the causes of erratic performance or differences of instrument readings for the same parameter, such as one instrument reading offset from another or divergent readings. 
Table 3. Summary of apparent deficiencies for key parameters

\begin{tabular}{|l|l|}
\hline \multicolumn{1}{|c|}{$\begin{array}{c}\text { Measured } \\
\text { parameters }\end{array}$} & \multicolumn{1}{c|}{ Anit 1 } \\
\hline $\begin{array}{l}\text { Reactor vessel } \\
\text { pressure }\end{array}$ & $\begin{array}{l}\text { Missing data, differences between instruments of about 0.5 MPa, } \\
\text { divergent data }\end{array}$ \\
\hline $\begin{array}{l}\text { Reactor vessel water } \\
\text { level }\end{array}$ & $\begin{array}{l}\text { Differences between instruments of about } 0.8 \mathrm{~m}, \text { missing data, calibration } \\
\text { errors due to reference columns with low/no water level, diverging data }\end{array}$ \\
\hline Containment pressure & Missing data \\
\hline Containment radiation & Data spikes, missing data \\
\hline \multicolumn{1}{|c|}{ Unit 2 } & Erroneous indication attributed to battery degradation, missing data \\
\hline $\begin{array}{l}\text { Reactor vessel } \\
\text { pressure }\end{array}$ & $\begin{array}{l}\text { Incorrect data due to undetected calibration problem, missing data, } \\
\text { differences between instruments }\end{array}$ \\
\hline $\begin{array}{l}\text { Reactor vessel water } \\
\text { level }\end{array}$ & Differences between instruments, erratic or missing data \\
\hline Containment pressure & $\begin{array}{l}\text { Data spikes, missing data, apparently low suppression pool radiation } \\
\text { values }\end{array}$ \\
\hline Containment radiation 3 & Differences between instruments \\
\hline $\begin{array}{l}\text { Reactor vessel } \\
\text { pressure }\end{array}$ & $\begin{array}{l}\text { Missing data possibly due to depleted batteries, differences between } \\
\text { instruments, divergent data }\end{array}$ \\
\hline $\begin{array}{l}\text { Reactor vessel water } \\
\text { level }\end{array}$ & Anomalous readings, missing data \\
\hline Containment pressure & Apparently low suppression pool radiation values \\
\hline Containment radiation &
\end{tabular}

The effects on other plant instrumentation are also considered in this section. This evaluation is patterned after that of Tables 5 and 6 in NUREG/CR-5444 (Ref. 14), shown in Appendix B of this report. Table 4 shows the list of plant instrumentation taken from Appendix B. The instrumentation is separated into categories based on the degree of environmental qualification and availability of backup power. Category 1 instruments are those that are fully environmentally qualified, redundant, provide real-time display, and have standby power (generally battery backup). Category 2 instrumentation meets less stringent qualifications - they may not be seismically qualified, may not have redundant continuous display, and may not have standby power. Category 3 instrumentation is least stringent, being high-quality, commercial-grade equipment powered only by offsite power. An engineering judgment was made whether instrument performance was degraded. Two cases were considered: first, whether the instrument was degraded by the loss of ac power or dc power (the ability to have ready, continuous, and accurate readings for all instrumentation was considered impacted); and second, whether the instrument would have been affected by the severe environmental conditions experienced in the accident. For this case, if the instrument environmental qualifications were exceeded, then the instrument was considered to be degraded. The term "degraded" denotes that accuracy of the reading - from the sensing element, cables, transmitters, etc., to the indicators or controls - cannot be assured. The environmental qualifications of all instrumentation was judged to be exceeded or affected by pressure, temperature, shock or vibration, impact, radiation, power quality, flooding, humidity, etc. The ability to perform grab sampling (i.e., manual sampling) was also considered to be degraded. 
Table 4. Summary of degraded instrumentation

\begin{tabular}{|c|c|c|c|}
\hline Plant Instrumentation & Category & $\begin{array}{l}\text { Degraded by Loss } \\
\text { of Power }\end{array}$ & $\begin{array}{c}\text { Degraded by Severe } \\
\text { Environmental Condition }\end{array}$ \\
\hline Reactor pressure & 1 & $\mathrm{Y}$ & $\bar{Y}$ \\
\hline Reactor water level & 1 & $\mathrm{Y}$ & $\mathrm{Y}$ \\
\hline Source range monitor & 1 & $\mathrm{Y}$ & $\mathrm{Y}$ \\
\hline $\begin{array}{l}\text { Intermediate range } \\
\text { monitor }\end{array}$ & 1 & $\mathrm{Y}$ & $\mathrm{Y}$ \\
\hline $\begin{array}{l}\text { Average power range } \\
\text { monitor }\end{array}$ & 1 & $\mathrm{Y}$ & $\mathrm{Y}$ \\
\hline $\begin{array}{l}\text { Suppression pool water } \\
\text { temperature }\end{array}$ & 1 & $\mathrm{Y}$ & $\mathrm{Y}$ \\
\hline $\begin{array}{l}\text { Suppression pool water } \\
\text { level }\end{array}$ & 1 & $\mathrm{Y}$ & $\mathrm{Y}$ \\
\hline Drywell pressure & 1 & $\mathrm{Y}$ & $\mathrm{Y}$ \\
\hline Drywell sump level & 1 & $\mathrm{Y}$ & $\mathrm{Y}$ \\
\hline $\begin{array}{l}\text { Primary containment } \\
\text { isolation valve position } \\
\text { (drywell) }\end{array}$ & 1 & $\mathrm{Y}$ & $\mathrm{Y}$ \\
\hline $\begin{array}{l}\text { Isolation valve position } \\
\text { (reactor building) }\end{array}$ & 1 & $\mathrm{Y}$ & $\mathrm{Y}$ \\
\hline $\begin{array}{l}\text { Containment and } \\
\text { drywell oxygen level }\end{array}$ & 1 & $\mathrm{Y}$ & $\mathrm{Y}$ \\
\hline $\begin{array}{l}\text { Containment and } \\
\text { drywell hydrogen } \\
\text { concentration }\end{array}$ & 1 & $\mathrm{Y}$ & $\mathrm{Y}$ \\
\hline $\begin{array}{l}\text { Containment area } \\
\text { radiation_-high range }\end{array}$ & 1 & $\mathrm{Y}$ & $\mathrm{Y}$ \\
\hline $\begin{array}{l}\text { Main steam isolation } \\
\text { valve position }\end{array}$ & 1 & $\mathrm{Y}$ & $\mathrm{Y}$ \\
\hline $\begin{array}{l}\text { Standby liquid control } \\
\text { system flow (pressure) }\end{array}$ & 2 & $\mathrm{Y}$ & $\mathrm{Y}$ \\
\hline $\begin{array}{l}\text { Standby liquid control } \\
\text { system storage tank } \\
\text { level }\end{array}$ & 2 & $\mathrm{Y}$ & $\mathrm{Y}$ \\
\hline $\begin{array}{l}\text { Primary system safety } \\
\text { relief valve position (of } \\
\text { flow) }\end{array}$ & 2 & $\mathrm{Y}$ & $\mathrm{Y}$ \\
\hline RCIC flow & 2 & $\mathrm{Y}$ & $\mathrm{Y}$ \\
\hline
\end{tabular}


Table 5. Summary of degraded instrumentation (continued)

\begin{tabular}{|c|c|c|c|}
\hline Plant Instrumentation & Category & $\begin{array}{l}\text { Degraded by Loss } \\
\text { of Power }\end{array}$ & $\begin{array}{c}\text { Degraded by Severe } \\
\text { Environmental Condition }\end{array}$ \\
\hline HPCI flow & 2 & $\mathrm{Y}$ & $\mathrm{Y}$ \\
\hline Core spray flow & 2 & $\mathrm{Y}$ & $\mathrm{Y}$ \\
\hline LPCI flow & 2 & $\mathrm{Y}$ & $\mathrm{Y}$ \\
\hline RHR system flow & 2 & $\mathrm{Y}$ & $\mathrm{Y}$ \\
\hline RCIC room temperature & 2 & $\mathrm{Y}$ & $\mathrm{Y}$ \\
\hline HPCI room temperature & 2 & $\mathrm{Y}$ & $\mathrm{Y}$ \\
\hline $\begin{array}{l}\text { RHR heat exchanger } \\
\text { outlet temperature }\end{array}$ & 2 & $\mathrm{Y}$ & $\mathrm{Y}$ \\
\hline $\begin{array}{l}\text { Suppression chamber } \\
\text { spray flow }\end{array}$ & 2 & $\mathrm{Y}$ & $\mathrm{Y}$ \\
\hline $\begin{array}{l}\text { Drywell atmosphere } \\
\text { temperature }\end{array}$ & 2 & $\mathrm{Y}$ & $\mathrm{Y}$ \\
\hline Drywell spray flow rate & 2 & $\mathrm{Y}$ & $\mathrm{Y}$ \\
\hline $\begin{array}{l}\text { Vent stack effluent } \\
\text { (radioactivity) }\end{array}$ & 2 & $\mathrm{Y}$ & $\mathrm{Y}$ \\
\hline $\begin{array}{l}\text { Emergency ventilation } \\
\text { damper position }\end{array}$ & 2 & $\mathrm{Y}$ & $\mathrm{Y}$ \\
\hline $\begin{array}{l}\text { Common plant vent or } \\
\text { multipurpose vent } \\
\text { release (unit vent) }\end{array}$ & 2 & $\mathrm{Y}$ & $\mathrm{Y}$ \\
\hline $\begin{array}{l}\text { Common plant vent or } \\
\text { multipurpose vent } \\
\text { release (offgas) }\end{array}$ & 2 & $\mathrm{Y}$ & $\mathrm{Y}$ \\
\hline $\begin{array}{l}\text { Status of power } \\
\text { (electrical and other } \\
\text { energy sources) }\end{array}$ & 2 & $\mathrm{Y}$ & $\mathrm{Y}$ \\
\hline $\begin{array}{l}\text { Control rod position } \\
\text { indicator }\end{array}$ & 3 & $\mathrm{Y}$ & $\mathrm{Y}$ \\
\hline $\begin{array}{l}\text { Reactor coolant system } \\
\text { boron concentration } \\
\text { (grab sample) }\end{array}$ & 3 & $\mathrm{Y}$ & $\mathrm{Y}$ \\
\hline $\begin{array}{l}\text { Main feedwater flow } \\
\text { rate }\end{array}$ & 3 & $\mathrm{Y}$ & $\mathrm{Y}$ \\
\hline $\begin{array}{l}\text { Primary loop } \\
\text { recirculation flow }\end{array}$ & 3 & $\mathrm{Y}$ & $\mathrm{Y}$ \\
\hline
\end{tabular}


Table 5. Summary of degraded instrumentation (continued)

\begin{tabular}{|l|c|c|c|}
\hline Plant Instrumentation & Category & $\begin{array}{c}\text { Degraded by Loss } \\
\text { of Power }\end{array}$ & $\begin{array}{c}\text { Degraded by Severe } \\
\text { Environmental Condition }\end{array}$ \\
\hline $\begin{array}{l}\text { Analysis of primary } \\
\text { coolant (gamma } \\
\text { spectrum) }\end{array}$ & 3 & $\mathrm{Y}$ & $\mathrm{Y}$ \\
\hline $\begin{array}{l}\text { Reactor building or } \\
\text { secondary containment } \\
\text { area radiation monitor }\end{array}$ & 3 & $\mathrm{Y}$ & $\mathrm{Y}$ \\
\hline Condenser vacuum & 3 & $\mathrm{Y}$ & $\mathrm{Y}$ \\
\hline $\begin{array}{l}\text { Condenser cooling water } \\
\text { flow }\end{array}$ & 3 & $\mathrm{Y}$ & $\mathrm{Y}$ \\
\hline $\begin{array}{l}\text { Condensate storage tank } \\
\text { level }\end{array}$ & 3 & $\mathrm{Y}$ & $\mathrm{Y}$ \\
\hline $\begin{array}{l}\text { Containment gases, } \mathrm{H}_{2}, \\
\mathrm{O}_{2}, \text { gamma (grab } \\
\text { sample) }\end{array}$ & 3 & $\mathrm{Y}$ & $\mathrm{Y}$ \\
\hline $\begin{array}{l}\text { Primary coolant activity, } \\
\text { boron, } \mathrm{H}_{2}, \mathrm{O}_{2}, \text { grab } \\
\text { sample) }\end{array}$ & 3 & $\mathrm{Y}$ & $\mathrm{Y}$ \\
\hline $\begin{array}{l}\text { Reactor building } \\
\text { pressure }\end{array}$ & 3 & $\mathrm{Y}$ & $\mathrm{Y}$ \\
\hline $\begin{array}{l}\text { Reactor building } \\
\text { temperature }\end{array}$ & 3 & & \\
\hline
\end{tabular}





\section{CONCLUSIONS}

The Fukushima Daiichi plant experienced essentially what would be expected based on the severe accident scenarios examined more than 20 years ago in research on BWR plants with a Mark I containment. Long-term SBO accidents during which dc electrical power was lost led to severe consequences to the reactor core and radiation release in these studies. The importance of instrumentation, control, and monitoring systems was noted repeatedly. However, lessons learned from past research were not fully implemented. For example, Table 5 presented a list of information needs lacking in BWR Mark I reactor designs in the early 1990s (repeated in Table 5). The instrumentation failures predicted by Alcieri and Hanson (Ref. 14) shown in Appendix B proved prescient at Fukushima Daiichi.

Table 6. Additional BWR Mark I information needs

\begin{tabular}{|l|l|}
\hline \multicolumn{1}{|c|}{ Information need } & \multicolumn{1}{c|}{ Direct information source } \\
\hline Control rod material location & None \\
\hline Core damage status & None \\
\hline Core materials and geometry & None \\
\hline Core melt location in drywell & None \\
\hline Core relocation status & None \\
\hline Drywell concrete ablated & None \\
\hline Drywell fission production concentration & None \\
\hline Drywell heat removal rate & None \\
\hline Drywell presence radiolytic products in water & None \\
\hline Drywell shell temperature & None \\
\hline Drywell water level & None \\
\hline Drywell/suppression chamber interface integrity & None \\
\hline Flow rate to condenser & None \\
\hline Fuel rod temperature & None \\
\hline Heat sink energy removal rate & None \\
\hline Interfacing systems pipe rupture location & None \\
\hline Nitrogen concentration & None \\
\hline Non-condensables in drywell & None \\
\hline Primary containment integrity & None \\
\hline SRV tailpipe integrity & None \\
\hline Suppression pool break location status & None \\
\hline $\begin{array}{l}\text { Suppression pool inadequate heat removal } \\
\text { capacity }\end{array}$ & None \\
\hline Suppression pool spray flow rate & None \\
\hline Vessel integrity & None \\
\hline
\end{tabular}

Very few of these information needs were assumed to be available during the Fukushima Daiichi accident, not because the instruments lost power and were inoperable, but because the capability was not likely present. (It is important to recognize that having this instrumentation capability does not mean the ability to mitigate these severe accident conditions would have been significantly affected.)

Although these information needs may not have been addressed to the point where additional instrumentation was provided, national and international responses were implemented to reduce the likelihood of severe accidents and to improve the plant capability to cope if a severe accident occurred in the intervening years. Examples of responses are the addition of the air-cooled diesel generators at Fukushima Daiichi Units 2, 4, and 6 to add redundancy to electrical power supply to 
better ensure operability of plant equipment, instrumentation, and accident monitoring and management. Unfortunately, connections to plant loads were made in the flooded electrical rooms; therefore, they were not usable in this event.

Containment venting capabilities were enhanced internationally to improve the ability to cope with high containment pressures and the potential venting of hydrogen during severe accidents. However, at Fukushima Daiichi, they were difficult to operate given a lack of control power, lack of highpressure air supplies, and difficult access under severe accident conditions.

Observations of instrument performance primarily associated with key parameters of RPV level and pressure, drywell pressure, and suppression pool pressure are shown in Table 7.

Table 7. Summary of apparent deficiencies for key parameters

\begin{tabular}{|c|c|}
\hline Measured parameters & Apparent deficiencies \\
\hline \multicolumn{2}{|l|}{ Unit 1} \\
\hline Reactor vessel pressure & $\begin{array}{l}\text { Missing data, differences between instruments of about } 0.5 \mathrm{MPa} \text {, } \\
\text { divergent data }\end{array}$ \\
\hline $\begin{array}{l}\text { Reactor vessel water } \\
\text { level }\end{array}$ & $\begin{array}{l}\text { Differences between instruments of about } 0.8 \mathrm{~m} \text {, missing data, } \\
\text { calibration errors due to reference columns with low/no water level, } \\
\text { diverging data }\end{array}$ \\
\hline Containment pressure & Missing data \\
\hline Containment radiation & Data spikes, missing data \\
\hline \multicolumn{2}{|l|}{ Unit 2} \\
\hline Reactor vessel pressure & Erroneous indication attributed to battery degradation, missing data \\
\hline $\begin{array}{l}\text { Reactor vessel water } \\
\text { level }\end{array}$ & $\begin{array}{l}\text { Incorrect data due to undetected calibration problem, missing data, } \\
\text { differences between instruments }\end{array}$ \\
\hline Containment pressure & Differences between instruments, erratic or missing data \\
\hline Containment radiation & $\begin{array}{l}\text { Data spikes, missing data, apparently low suppression pool radiation } \\
\text { values }\end{array}$ \\
\hline \multicolumn{2}{|r|}{ 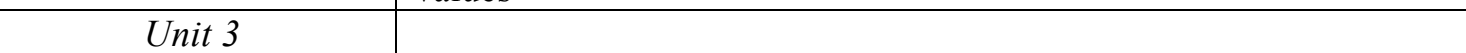 } \\
\hline Reactor vessel pressure & Differences between instruments \\
\hline $\begin{array}{l}\text { Reactor vessel water } \\
\text { level }\end{array}$ & $\begin{array}{l}\text { Missing data possibly due to depleted batteries, differences between } \\
\text { instruments, divergent data }\end{array}$ \\
\hline Containment pressure & Anomalous readings, missing data \\
\hline Containment radiation & Apparently low suppression pool radiation values \\
\hline
\end{tabular}

All plant instrumentation was considered to be degraded as a consequence of the accident, either by loss of power or by exceeding equipment environmental qualifications.

There are some important observations or potential lessons learned regarding the Fukushima Daiichi accident:

- Unit 1 experienced core damage in a few hours, in part due to the loss of monitoring and control of the isolation condenser system. Apparently, during the almost simultaneous loss of both ac and dc power, the ac and dc isolation valves for the two isolation condensers closed. This appeared to be an unexpected valve state. Considerable effort was spent trying to open dc powered valves so that the system would operate; however, the closed ac power valves prevented system operation.

- At Unit 2, the RCIC operated essentially hands off under manual control longer than expected, with system shutdown being prevented because the lack of control power prevented shutdown conditions from causing shutdown (Ref. 30). 
- At Unit 3, RCIC and HPCI also operated longer than expected using manual control (Ref. 27).

- Provision of redundant and diverse electrical power supplies. Redundant trains of both ac and dc electrical power systems were lost due to seawater flooding of dc system batteries and ac system switchgear. Diversity in electrical supply to resist flooding was absent and, therefore, the benefits of redundancy in supply were lost.

- Provision of adequate direct information needs. Was necessary information to guide timely and effective emergency response provided? Was the capability to provide all important parameters present? Was it able to be used?

- Local instrumentation racks in the reactor buildings used for reactor and containment monitoring were difficult to access. The Finnish study (Ref. 15) recommended the addition of new instrumentation for containment pressure, reactor pressure, water level inside the lower drywell, and drywell/wetwell pressure difference to help prevent early containment failure. It also noted that measurements are provided in a central panel in a special emergency monitoring center close to the front door of the reactor building.

- Reconsider the vulnerabilities, recommendations, and lessons learned from prior severe accident research and recent post-Fukushima assessments. Publically share the national and international responses to the Fukushima Daiichi accidents, such as the U.S. industry diverse and flexible coping capability (FLEX) (Ref. 2) and the European Nuclear Safety Regulators Group (ENSREG) reactor stress test results (Ref. 3).

Although loss of instrument power was the initial reason for the loss of instrument capability, the harsh severe accident environmental conditions almost certainly exceeded equipment environmental qualifications for key instrumentation shown in Appendix B. These important factors were not thoroughly examined in the major accident investigation reports that were sources of information for this review. Additional research is warranted to investigate root causes and specific failure modes. In the near term, four additional tasks are envisioned as being necessary to complete the evaluation of accident tolerant instrumentation.

\section{Task 1: Document Key Parameters for Operator Diagnosis of Plant Condition}

The first task following this report should determine and document the key parameters for operator diagnosis of plant condition. Through a review of literature and other relevant knowledge bases (e.g., plant-specific and owner group generic EOPs as well as severe accident management guidelines), a list of key plant parameters most essential for operators to diagnose the state of the plant and prevent or mitigate severe accidents needs to be developed. This is essentially a function needs analysis intended to be a first principles needs analysis; it should not be limited to looking at parameters that are currently monitored.

\section{Task 2: Determine Essential Instrument Environmental Conditions}

The second task following this report should determine the environmental conditions of essential instrumentation. The NRC SOARCA project (Ref. 1) results can be used to develop best estimates of the offsite radiological health consequences for potential severe reactor accidents. SOARCA analyzed the potential consequences of severe accidents at the Surry Power Station and the Peach Bottom Atomic Power Station. Because this SOARCA information represents the most complete, up-to-date evaluations of conditions that may occur at U.S. nuclear power plants for a range of severe accidents, the SOARCA plants should be selected as pilot plants for this task. Specifically, this task will review plant-specific calculation results for the SOARCA Peach Bottom BWR and the Surry PWR to quantify, to the extent possible, the environment (e.g., pressures, temperatures, integrated radiation dose, seismic fragility) that essential instruments would have to survive to remain functional during 
risk-dominant severe accidents for two pilot plants (one BWR and one PWR). It should also be noted that the source of instrument failure may not be the sensor itself; for example, the wiring that transmits the instrument signal may fail first. Therefore, for this task the "instrument" should include all associated components (e.g., wiring, power supply) necessary for correct operation. The impact of re-establishing power from alternate power sources that are currently implemented as part of the B.5.b measures implemented at U.S. plants and from measures that will be implemented in measures identified by the NRC and industry after the Fukushima Daiichi events (e.g., NTTF activities, FLEX measures) should also be considered.

\section{Task 3: Examine Functional Requirements for Essential Measurements}

The third task following this report should examine the functional requirements for essential measurements. Based on the results of the above tasks, a determination is needed of what monitoring capabilities should be further developed. These requirements should be expressed as functional requirements (e.g., the ability to measure water level to within plus or minus 5 in. during pressures up to the reactor vessel maximum design pressure) rather than as a sensor-specific recommendation.

\section{Task 4: Develop Recommendations and Issue Final Reports}

Based on the tasks discussed above, the fourth task should provide specific recommendations regarding plant instrumentation research and development to provide the monitoring capabilities identified in the functional requirements. As part of this task, input and participation will be solicited from interested stakeholders from utilities, plant designers, Japanese organizations, the NRC, and the instrumentation industry. 


\section{REFERENCES}

1. http://www.nrc.gov/about-nrc/regulatory/research/soar.html.

2. ANSI/ANS-59.51, Fuel Oil Systems for Safety-Related Emergency Diesel Generators, American Nuclear Society, reaffirmed October 2007.

3. R. B. Gallaher, R. H. Guymon, G. T. Mays, W. P. Poore, R. J. Cagle, Sequence Coding and Search System for Licensee Event Reports-Coder's Manual, NUREG/CR-3905 LD, Volume 4, Rev. 1, November 1984.

4. U.S. Nuclear Regulatory Commission, Boiling Water Reactor Systems Manual, circa 1982.

5. U.S. Nuclear Regulatory Commission, Introduction to Reactor Technology-BWR, Chapter 3.0, Reactor Vessel Instrumentation System, http://pbadupws.nrc.gov/docs/ML1215/ML12158A333.pdf.

6. North Anna Power Station Unit 1 and 2 Licensee Event Report, 338/2011-003, https://lersearch.inl.gov/PDFView.ashx?DOC::3382011003R00.PDF.

7. American Nuclear Society, Fukushima Daiichi: ANS Committee Report, Appendix F-Safety System Descriptions for Station Blackout: Isolation Condenser, Reactor Core Isolation Cooling, and High Pressure Coolant Injection, March 2012, http://fukushima.ans.org/inc/Fukushima_Appendix_F.pdf.

8. American Nuclear Society, Appendix F-Safety System Descriptions for Station Blackout Mitigation: Isolation Condenser, Reactor Core Isolation Cooling, and High-Pressure Coolant Injection, Fukushima Daiichi: ANS Committee Report, March 2012 (Revised June 2012), Appendix F, http://fukushima.ans.org/inc/Fukushima_Appendix_F.pdf.

9. As noted in U.S. Nuclear Regulatory Commission Regulatory Guide 1.97-Criteria for Accident Monitoring Instrumentation for Nuclear Power Plants, Revision 4, June 2006.

10. For an informative overview see S. R. Greene, The Canary, the Ostrich, and the Black Swan: An Historical Perspective on our Understanding of BWR Severe Accidents and their Mitigation, American Nuclear Society International Meeting on Severe Accident Assessment and Management: Lessons Learned from Fukushima Dai-ichi, November 12, 2012, San Diego, CA.

11. Reactor Safety Study: An Assessment of Accident Risk in U. S. Commercial Nuclear Power Plants, WASH-1400 ( NUREG-75-014), U.S. Nuclear Regulatory Commission, October 1975.

12. Station Blackout at Browns Ferry Unit One-Accident Sequence Analysis, NUREG/CR2182, November 1981.

13. D. N. Chien, D. J. Hanson, Accident Management Information Needs for a BWR with a MARK I Containment, NUREG/CR-5702, Idaho National Engineering Laboratory, May 1991.

14. W. C. Arcieri, D. J. Hanson, Instrumentation Availability During Severe Accidents for a Boiling Water Reactor with the Mark I Containment, NUREG/CR-5444, Idaho National Engineering Laboratory, February 1992. 
15. Harri Tuomisto, Arto Felin, et. al., Severe Accident Management Instrumentation in the Finnish NPPs, circa 1989.

16. The official report of The Fukushima Nuclear Accident Independent Investigation Commission, The National Diet of Japan, 2012, http://warp.da.ndl.go.jp/info:ndljp/pid/3856371/naiic.go.jp/en/report/.

17. Tokyo Electric Power Company, Inc., Fukushima Nuclear Accident Analysis Report, June 20, 2012, http://www.tepco.co.jp/en/press/corp-com/release/2012/1205638_1870.html.

18. U.S. Nuclear Regulatory Commission, Recommendations for Enhancing Reactor Safety in the $21^{\text {st }}$ Century-The Near-Term Task Force Review of Insights from the Fukushima Daiichi Accident, July 12, 2011, http://pbadupws.nrc.gov/docs/ML1125/ML112510271.pdf.

19. IAEA Mission Report, The Great East Japan Earthquake Expert Mission-IAEA International Fact Finding Expert Mission of the Fukushima Dai-ichi NPP Accident Following the Great East Japan Earthquake and Tsunami, May 24-June 2, 2011, http://wwwpub.iaea.org/mtcd/meetings/pdfplus/2011/cn200/documentation/cn200 final-fukushimamission_report.pdf.

20. Nuclear Emergency Response Headquarters Government of Japan, Additional Report of the Japanese Government to the IAEA-The Accident at TEPCO's Fukushima Nuclear Power Stations (Second Report), September 2011, http://www.iaea.org/newscenter/focus/fukushima/japan-report2/.

21. Nuclear and Industrial Safety Agency (Japan), Technical Knowledge of the Accident at Fukushima Dai-ichi Nuclear Power Station of Tokyo Electric Power Co., Inc. (Provisional Translation), March 2012, http://www.nsr.go.jp/archive/nisa/english/press/2012/06/en20120615-1-1.pdf.

22. Japan Nuclear Technology Institute, Examination of Accident at Tokyo Electric Power Co., Inc.'s Fukushima Daiichi Nuclear Power Stations and Proposal of Countermeasures, October 2011, http://www.gengikyo.jp/english/.

23. Masaya Yasui, Deputy Director General, Nuclear Safety Regulation Reform Ministry of Economy, Trade and Industry (METI), Causes and Countermeasures: The Accident at TEPCO's Fukushima Nuclear Power Stations, March 2012, http://www.oecdnea.org/nsd/fukushima/documents/NISAFukushimacausesandcountermeasuresMarch2012 en .pdf.

24. Institute for Nuclear Power Operations, Special Report on the Nuclear Accident at the Fukushima Daiichi Nuclear Power Station, Revision 0, INPO 11-005, November 2011, http://www.nei.org/resourcesandstats/documentlibrary/safetyandsecurity/reports/specialreport-on-the-nuclear-accident-at-the-fukushima-daiichi-nuclear-power-station.

25. Electric Power Research Institute (EPRI), Fukushima Daiichi Accident-Technical Causal Factor Analysis, No. 1024946, March 2012, http://www.epri.com/abstracts/Pages/ProductAbstract.aspx?ProductId=000000000001024946

26. American Nuclear Society (ANS), Fukushima Daiichi: ANS Committee Report, March 2012, http://fukushima.ans.org/report/Fukushima report.pdf.

27. R. Chang, J. Schaperow, T. Ghosh, J. Barr, C. Tinkler, M. Stutzke, State-of-the-Art Reactor Consequences Analyses (SOARCSA) Report - Draft for Comment, NUREG-1935, January 2012, p. 95.

28. http://safetyfirst.nei.org/industry-actions/flex-the-industry-strategy-to-enhance-safety/. 
29. http://www.ensreg.eu/EU-Stress-Tests.

30. R. Chang, J. Schaperow, T. Ghosh, J. Barr, C. Tinkler, M. Stutzke, State-of-the-Art Reactor Consequences Analyses (SOARCSA) Report - Draft for Comment, NUREG-1935, January 2012, p. 95.

31. http://www.tepco.co.jp/en/nu/fukushima-np/f1/pla/2011/index-e.html. 



\section{APPENDIX A-PARTIAL BIBLIOGRAPHY OF LIGHT WATER SAFETY}

PUBLICATIONS 1975-2010

A-1 



\section{Appendix A. PARTIAL BIBLIOGRAPHY OF LIGHT WATER SAFETY PUBLICATIONS 1975-2010}

1. "Quarterly Progress Report on Fission Product Release From LWR Fuel for the Period AprilJune 1975”, A. P. Malinauskas, R. A. Lorenz, M. F. Osborne, J. L. Collins, and S. R. Manning, ORNL-TM-5021, Oak Ridge National Laboratory, September 1975.

2. "Quarterly Progress Report on Fission Product Release From LWR Fuel for the Period JulySeptember 1975”, A. P. Malinauskas, R. A. Lorenz, M. F. Osborne, J. L. Collins, and S. R. Manning,ORNL-TM-5143, Oak Ridge National Laboratory, November 1975.

3. "Quarterly Progress Report on Fission Product Release From LWR Fuel for the Period OctoberDecember 1975", R. A. Lorenz, J. L. Collins, and S. R. Manning, ORNL-TM-5290, Oak Ridge National Laboratory, March 1976.

4. "Knudsen Cell-Mass Spectrometer Studies of Cesium-Urania Interactions", J. L. Collins, M. F. Osborne, A. P. Malinauskas, R. A. Lorenz, and S. R. Manning, ORNL/NUREG/TM-24, Oak Ridge National Laboratory, June 1976.

5. "Behavior of Iodine, Methyl Iodide, Cesium Oxide, and Cesium Iodide in Steam and Argon", R. A. Lorenz, M. F. Osborne, J. L. Collins, S. R. Manning, and A. P. Malinauskas, ORNL/NUREG/TM-25, Oak Ridge National Laboratory, July 1976.

6. "Quarterly Progress Report on Fission Product Release From LWR Fuel for the Period JanuaryMarch 1976", R. A. Lorenz, J. L. Collins, S. R. Manning, and A. P. Malinauskas, ORNL/NUREG/TM-30, Oak Ridge National Laboratory, July 1976.

7. "Quarterly Progress Report on Fission Product Release From LWR Fuel for the Period AprilJune 1976”, R. A. Lorenz, J. L. Collins, S. R. Manning, O. L. Kirkland, and A. P. Malinauskas, ORNL/NUREG/TM-44, Oak Ridge National Laboratory, August 1976.

8. "Quarterly Progress Report on Fission Product Release From LWR Fuel for the Period JulySeptember 1976", R. A. Lorenz, J. L. Collins, and O. L. Kirkland, ORNL/NUREG/TM-73, Oak Ridge National Laboratory, December 1976.

9. "Quarterly Progress Report on Fission Product Release From LWR Fuel for the Period OctoberDecember 1976", R. A. Lorenz, J. L. Collins, and O. L. Kirkland, ORNL/NUREG/TM-88, Oak Ridge National Laboratory, March 1977.

10. "Fission Product Release from Simulated LWR Fuel", R. A. Lorenz, J. L. Collins, and A. P. Malinauskas, in Proceedings of the Specialist Meeting on the Behavior of Water Reactor Fuel Elements Under Accident Conditions, Spatind, Norway, Sept. 13-16, 1976 (CSNI Report No. 13), Part Two, Session I, Subsession I.3, March 1977.

11. "Quarterly Progress Report on Fission Product Release From LWR Fuel for the Period AprilJune 1977”, A. P. Malinauskas, R. A. Lorenz, J. L. Collins, O. L. Kirkland, and R. L. Towns, ORNL/NUREG/TM-139, Oak Ridge National Laboratory, September 1977.

12. "Quarterly Progress Report on Fission Product Release From LWR Fuel for the Period JulySeptember 1977”, A. P. Malinauskas, R. A. Lorenz, J. L. Collins, M. F. Osborne, O. L. Kirkland, and R. L. Towns, ORNL/NUREG/TM-110, Oak Ridge National Laboratory, January 1978. 
13. "Quarterly Progress Report on Fission Product Release From LWR Fuel for the Period OctoberSeptember 1977”, A. P. Malinauskas, R. A. Lorenz, J. L. Collins, M. F. Osborne, and R. L. Towns, ORNL/NUREG/TM-186, Oak Ridge National Laboratory, March 1978.

14. "Fission Product Release from Highly Irradiated Fuel Under SFTA and LOCA Conditions", J. L. Collins and R. A. Lorenz, presented at the 80th Annual Meeting of the American Ceramic Society, Detroit, MI, May 1978.

15. "Modeling Fission Product Release from Ruptured LWR Fuel Rods", R. A. Lorenz, J. L. Collins, and A. P. Malinauskas, presented at the 1978 Annual Meeting of the American Nuclear Society, San Diego, CA, June 1978.

16. "Fission Product Source Terms for Loss-of-Coolant Accident: Summary Report", R. A. Lorenz, J. L. Collins, and A. P. Malinauskas, NUREG/CR-0091 (ORNL/NUREG/TM-206), Oak Ridge National Laboratory, June 1978.

17. "Quarterly Progress Report on Fission Product Release From LWR Fuel for the Period JanuaryMarch 1978”, A. P. Malinauskas, R. A. Lorenz, J. L. Collins, M. F. Osborne, and R. L. Towns, NUREG/CR-0116 (ORNL/NUREG/TM-208), Oak Ridge National Laboratory, June 1978.

18. "Quarterly Progress Report on Fission Product Release From LWR Fuel for the Period AprilJune 1978", A. P. Malinauskas, R. A. Lorenz, J. L. Collins, M. F. Osborne, and R. L. Towns, NUREG/CR-0370 (ORNL/NUREG/TM-242), Oak Ridge National Laboratory, September 1978.

19. "Fission Product Release from Simulated LWR Fuel”, R. A. Lorenz, J. L. Collins, and S. R. Manning, NUREG/CR-0274 (ORNL/NUREG/TM-154), Oak Ridge National Laboratory, October 1978.

20. "Fission Product Source Terms for the LWR Loss-of-Coolant Accident", R. A. Lorenz, J. L. Collins, and A. P. Malinauskas, in Proceedings of the ENS/ANS International Topical Meeting on Nuclear Power Reactor Safety, Brussels, Belgium, Oct. 16-19, 1978, Vol. 3, p. 2293 (October 1978).

21. "Quarterly Progress Report on Fission Product Release From LWR Fuel for the Period JulySeptember 1978”, A. P. Malinauskas, R. A. Lorenz, J. L. Collins, M. F. Osborne, and R. L. Towns, NUREG/CR-0493 (ORNL/NUREG/TM-280), December 1978.

22. "Fission-Product Source Terms for the Light Water-Reactor Loss-of-Coolant Accident", R. A. Lorenz, J. L. Collins, and A. P. Malinauskas, Nuclear Technology, 46(3), p. 404-410 (1979).

23. "Fission-Product Release During LWR Loss-of-Coolant Accidents", A. P. Malinauskas, R. A. Lorenz, and J. L. Collins, Transactions of the American Nuclear Society, 32, p. 651 (1979).

24. "Quarterly Progress Report on Fission Product Release From LWR Fuel for the Period OctoberDecember 1978”, A. P. Malinauskas, R. A. Lorenz, J. L. Collins, M. F. Osborne, and R. L. Towns, NUREG/CR-0682 (ORNL/NUREG/TM-308), Oak Ridge National Laboratory, April 1979.

25. "Quarterly Progress Report on Fission Product Release From LWR Fuel for the Period JanuaryMarch 1978”, A. P. Malinauskas, R. A. Lorenz, J. L. Collins, M. F. Osborne, and R. L. Towns,

26. NUREG/CR-917 (ORNL/NUREG/TM-332), Oak Ridge National Laboratory, August 1979. 
27. "Fission Product Release from LWR Fuel Defected in Steam in the Temperature Range 500 to $1600^{\circ}$ C", R. A. Lorenz, J. L. Collins, M. F. Osborne, and A. P. Malinauskas, in Proceedings of the Specialists' Meeting on the Behavior of Defected Zirconium Alloy Clad Ceramic Fuel in Water Cooled Reactors, Chalk River, Canada, Sept. 17-21, 1979, International Atomic Energy Agency, IWGFPT/6, (1979).

28. "Chemical Behavior of Fission Products Released from Highly Irradiated LWR Fuel Under Accident Conditions", J. L. Collins, R. A. Lorenz, A. P. Malinauskas, and M. F. Osborne, presented at the Basic Science and Nuclear Divisions of the American Ceramic Society's Joint Fall Meeting, New Orleans, LA, October 1979.

29. "Quarterly Progress Report on Fission Product Release From LWR Fuel for the Period AprilJune 1978", A. P. Malinauskas, R. A. Lorenz, J. L. Collins, M. F. Osborne, and R. L. Towns, NUREG/CR-1061 (ORNL/NUREG/TM-348), Oak Ridge National Laboratory, October 1979.

30. "Fission-Product Release from High Gap-Inventory LWR Fuel Under LOCA Conditions", R. A. Lorenz, J. L. Collins, M. F. Osborne, et al., Transactions of the American Nuclear Society, 34, pp. $462-463(1980)$.

31. "Fission Product Release from Highly Irradiated LWR Fuel”, R. A. Lorenz, J. L. Collins, A. P. Malinauskas, O. L. Kirkland, and R. L. Towns, NUREG/CR-0722 (ORNL/NUREG/TM-287/R2), Oak Ridge National Laboratory, February 1980.

32. "Fission Product Source Terms for the LWR Loss-of-Coolant Accident", R. A. Lorenz, J. L. Collins, and A. P. Malinauskas, NUREG/CR-1288 (ORNL/NUREG/CR-321), Oak Ridge National Laboratory, August 1980.

33. "Fission Product Release from Highly Irradiated LWR Fuel Heated to $1300-1600^{\circ} \mathrm{C}$ in Steam", R. A. Lorenz, J. L. Collins, A. P. Malinauskas, M. F. Osborne, and R. L. Towns, NUREG/CR1386 (ORNL/NUREG/TM-346), Oak Ridge National Laboratory, November 1980.

34. "The Adsorption-Desorption Characteristics of Iodine on Graphite", R. A. Lorenz, Transactions of the American Nuclear Society, 39, pp. 444-445 (1981).

35. "Sorption of Iodine on Low-Chromium Alloy-Steel", M. F. Osborne, R. B. Briggs, and R. P. Wichner, Transactions of the American Nuclear Society,38, pp. 463-464 (June 1981).

36. "Fission Product Release from BWR Fuel Under LOCA Conditions", R. A. Lorenz, J. L. Collins, M. F. Osborne, R. L. Towns, and A. P. Malinauskas, NUREG/CR-1773 (ORNL/NUREG/TM388), Oak Ridge National Laboratory, July 1981.

37. "Station Blackout at Browns Ferry Unit One-Accident Sequence Analysis", D. H. Cook, R. M. Harrington, S. R. Greene, S. A. Hodge, and D. D. Yue, NUREG/CR-2182, Vol. 1 (ORNL/NUREG/TM-455/V1), Oak Ridge National Laboratory, November 1981.

38. "Station Blackout at Browns Ferry Unit One-Iodine and Noble Gas Distribution and Release", R. P. Wichner, C. F. Weber, R. A. Lorenz, W. Davis, Jr., S. A. Hodge, and A. D. Mitchell, NUREG/CR-2182, Vol. 2 (ORNL/NUREG/TM-455/V2), Oak Ridge National Laboratory, 1982.

39. "Fission-Product Release from LWR Fuel in Steam", M. F. Osborne, R. A. Lorenz, and R. P. Wichner, Transactions of the American Nuclear Society,43, pp. 357-359 (1982). 
40. "Investigation of Drywell Flooding at the Browns Ferry Nuclear Plant", S. R. Greene, W. A. Condon, and H. L. Dodds, Jr., presented at American Nuclear Society Summer Meeting, Los Angeles, CA, June (1982).

41. "Application of MARCH to BWR Severe Accident Analysis", S. R. Greene, in Proceedings of the 10th Water Reactor Safety Information Meeting, Gaithersburg, MD, October (1982).

42. "Improvement of MARCH for BWR Applications", S. R. Greene, in Proceedings of the 10th Water Reactor Safety Information Meeting, Gaithersburg, MD, October (1982).

43. "SBLOCA Outside Containment at Browns Ferry Unit One-Accident Sequence Analysis", W. A. Condon, R. M. Harrington, S. R. Greene, and S. A. Hodge, NUREG/CR2672, Volume 1 (ORNL/TM-8119/V1), Oak Ridge National Laboratory, November 1982.

44. "Severe Accident Sequence Analysis (SASA)", S. R. Greene, presented to R. Minogue, Director, Office of Nuclear Regulatory Research, U.S. Nuclear Regulatory Commission, Oak Ridge, TN, December 10, 1982.

45. "SBLOCA Outside Containment at Browns Ferry Unit One-Volume 2. Iodine, Cesium, and Noble Gas Distribution and Release", R. P. Wichner, C. F. Weber, A. L. Wright, S. A. Hodge, R. A. Lorenz, and J. W. Nehls, NUREG/CR-2672, Volume 2 (ORNL/TM-8119/V2), Oak Ridge National Laboratory, 1983.

46. "Fission-Product Transport in A BWR Small-Break LOCA", C. F. Weber, R. P. Wichner, S. A. Hodge, et al., Transactions of the American Nuclear Society, 45, pp. 479-480 (1983).

47. "Iodine Volatility Under LWR Accident Conditions", E. C. Beahm and W. E. Shockley, Transactions of the American Nuclear Society, 45, pp. 482-483 (1983).

48. "Loss of DHR Sequences at Browns Ferry Unit One-Accident Sequence Analysis", D. H. Cook, S. R. Greene, R. M. Harrington, and S. A. Hodge, NUREG/CR-2973 (ORNL/TM-8532), Oak Ridge National Laboratory, May 1983.

49. "Fission Product Release from Fuel Under LWR Accident Conditions", M. F. Osborne, R. A. Lorenz, K. S. Norwood, J. L. Collins, and R. P. Wichner, p. 4.1-1 in Proceedings of the International Meeting on Light-Water Reactor Severe Accident Evaluation, Cambridge, Mass., Aug. 28-Sept. 1, 1983, CONF-830816, Vol. 1 (1983).

50. "The Effect of Small-Capacity, High-Pressure Injection Systems on TQUV Sequences at Browns Ferry Unit One", R. M. Harrington and L. J. Ott, NUREG/CR-3179 (ORNL/TM-8635), Oak Ridge National Laboratory, September 1983.

51. "The Effect of Low Capacity Injection Systems on Transient Initiated Loss of Vessel Water Injection at Browns Ferry Unit One", L. J. Ott, presented at the International Meeting on Light Water Reactor Severe Accident Evaluation, Cambridge MA, August 28-September 1, 1983.

52. "The Effect of Small-Capacity, High-Pressure Injection Systems on BWR Transient Initiated Loss of Injection Accident Sequences", L. J. Ott, presented at the Eleventh Water Reactor Safety Research Information Meeting, Gaithersburg, MD, October 24-28, (1983).

53. "Mechanistic Core-Wide Meltdown and Relocation Modeling for BWR Applications", M. Z. Podowski, R. P. Taleyarkhan, and R. T. Lahey, Jr., NUREG/CR-3525 (ORNL/Sub/81-9080/1), Oak Ridge National Laboratory, December 1983. 
54. "Realistic Simulation of Severe Accidents in BWRs - Computer Modeling Requirements", S. R. Greene, NUREG/CR-2940 (ORNL/TM-8517), Oak Ridge National Laboratory, 1984.

55. "Behavior of Cesium, Iodine, and Tellurium in the Fission-Product Release Program at ORNL", J. L. Collins, M. F. Osborne, and R. A. Lorenz, Transactions of the American Nuclear Society, 47, pp. 320-322 (1984).

56. "Noble Gas, Iodine, and Cesium Transport in a Postulated Loss of Decay Heat Removal Accident at Browns Ferry", R. P. Wichner, C. F. Weber, S. A. Hodge, E. C. Beahm, and A. L. Wright, NUREG/CR-3617 (ORNL/TM-9028), Oak Ridge National Laboratory, 1984.

57. "Data Summary Report for Fission Product Release Test HI-4", M. F. Osborne, J. L. Collins, R. A. Lorenz, K. S. Norwood, J. R. Travis, and C. S. Webster, NUREG/CR-3600 (ORNL/TM9001), Oak Ridge National Laboratory, June 1984.

58. "Characterization and Chemistry of Fission Products Released from LWR Fuel Under Accident Conditions", K. S. Norwood, J. L. Collins, M. F. Osborne, R. A. Lorenz, and R. P. Wichner, in Proceedings of the ANS Topical Meeting on Fission Product Behavior and Source Term Research, Snowbird, Utah, July 15-19, (1984).

59. "Noble Gas, Iodine, and Cesium Transport in A Postulated Loss of Decay Heat Removal Accident at Browns Ferry", R. P. Wichner, S. A. Hodge, C. F. Weber, E. C. Beahm, and A. L. Wright, NUREG/CR-3617 (ORNL/TM-9028), Oak Ridge National Laboratory, August 1984.

60. "Design, Construction, and Testing of a $2000^{\circ} \mathrm{C}$ Furnace and Fission Product Collection System", M. F. Osborne, J. L. Collins, R. A. Lorenz, J. R. Travis, and C. S. Webster, NUREG/CR-3715 (ORNL/TM-9135), Oak Ridge National Laboratory, September 1984.

61. "Pressure Suppression Pool Thermal Mixing, D. H. Cook", NUREG/CR-3471 (ORNL/TM8906), Oak Ridge National Laboratory, October 1984.

62. "Chemical Factors Affecting Fission Product Transport in BWR Severe Accidents", E. C. Beahm, R. P. Wichner, and C. F. Weber, Trans. of 12th Water Reactor Safety Research Information Meeting, U. S. Nuclear Regulatory Commission, Gaithersburg MD, October 23, (1984).

63. "Effects of Improved Modeling on Best Estimate BWR Severe Accident Analysis", L. J. Ott and C. R. Hyman, presented at the Twelfth Water Reactor Safety Research Information Meeting, Gaithersburg, MD, October 23, (1984).

64. "Behavior of Cs, I, and Te in the Fission Product Release Program at ORNL", J. L. Collins, M. F. Osborne, and R. A. Lorenz, Transactions of 1984 Winter Meeting of American Nuclear Society, 47, pp. 320-22, Washington, DC, Nov. 11-16, (1984).

65. "Measurement and Characterization of Fission Products Released from LWR Fuel", M. F. Osborne, J. L. Collins, R. A. Lorenz, K. S. Norwood, and R. V. Strain, in Proceedings of the Fifth International Meeting on Thermal Nuclear Reactor Safety, , Karlsruhe, Federal Republic of Germany, Sept. 9-13, 1984, Vol. 3 (published December 1984 as KfK 3880/1, -/2, -/3) (1984).

66. "A Chemical-Equilibrium Estimate of the Aerosols Produced in An Overheated Light WaterReactor Core", R. P. Wichner and R. D. Spence, Nuclear Technology, 70 (3), pp. 376-393 (1985). 
67. "BWR-LTAS: A Boiling Water Reactor Long-Term Accident Simulation Code", R. M. Harrington and L. C. Fuller, NUREG/CR-3764 (ORNL/TM-9163), Oak Ridge National Laboratory, February 1985.

68. Observed Behavior of Cesium, Iodine, and Tellurium in the ORNL Fission Product Release Program, J. L. Collins, M. F. Osborne, R. A. Lorenz, K. S. Norwood, J. R. Travis, and C. S. Webster, NUREG/CR-3930 (ORNL/TM-9316), Oak Ridge National Laboratory, February 1985.

69. Highlights Report for Fission Product Release Tests at Simulated LWR Fuel, M. F. Osborne, J. L. Collins, and R. A. Lorenz, ORNL/NRC/LTR-85/1, Oak Ridge National Laboratory, February 1985.

70. The Modeling of BWR Core Meltdown Accidents-For Application in the MELRPI.MOD2 Computer Code, B. R. Koh, S. H. Kim, R. P. Taleyarkhan, M. Z. Podowski, and R. T. Lahey, Jr., NUREG/CR-3889 (ORNL/Sub/81-9088/2), Oak Ridge National Laboratory, April 1985.

71. "Tellurium Precursor Effects on Iodine Transport in A BWR Accident", C. F. Weber, R. P. Wichner, and S. A. Hodge, Transactions of the American Nuclear Society, 49, pp. 257-258 (June 1985).

72. Data Summary Report for Fission Product Release Test HI-5, M. F. Osborne, J. L. Collins, R. A. Lorenz, K. S. Norwood, J. R. Travis, and C. S. Webster, NUREG/CR-4037 (ORNL/TM-9437), Oak Ridge National Laboratory, June 1985.

73. The Absorption of Gaseous Iodine by Water Droplets, M. F. Albert, NUREG/CR-4081 (ORNL/TM-9488), Oak Ridge National Laboratory, July 1985.

74. Data Summary Report for Fission Product Release Test HI-6, M. F. Osborne, J. L. Collins, R. A. Lorenz, K. S. Norwood, J. R. Travis, and C. S. Webster, NUREG/CR-4043 (ORNL/TM-9443), Oak Ridge National Laboratory, September 1985.

75. "Station Blackout Calculations for Browns Ferry", L. J. Ott, C. R. Hyman, and C. F. Weber, presented at the Thirteenth Water Reactor Safety Research Information Meeting, Gaithersburg, $\mathrm{MD}$, October 22-25, 1985; also in Proc. 13th Water Reactor Safety Research Information Meeting, NUREG/CP-0071, 1985.

76. "Chemistry and Transport of Iodine in Containment", E. C. Beahm, W. E. Shockley, and C. F. Weber, presented at the International Symposium on Source Term Evaluation for Accident Conditions, Columbus, OH, October 28-November 1, 1985.

77. "Fission Product Release and Fuel Behavior in Tests of LWR Fuel Under Accident Conditions", M. F. Osborne, J. L. Collins, R. A. Lorenz, and R. V. Strain, in Proceedings of the International Symposium on Source Term Evaluation for Accident Conditions, Columbus, OH, Oct. 28-Nov. $1,1985$.

78. "Fission Product Release from UO2Under LWR Accident Conditions: Recent Data Compared with Review Values", M. F. Osborne, J. L. Collins, and R. A. Lorenz, presented at the 87th Annual Meeting of American Ceramic Society, Cincinnati, Ohio, May 5-9, 1985; also in Advances in Ceramics 17, pp. 191-97 (1986). 
79. Chemistry and Transport of Iodine in Containment, E. C. Beahm, W. E. Shockley, C. F. Weber, S. J. Wisbey, and Y.-M. Wang, NUREG/CR-4697 (ORNL/TM-10135), Oak Ridge National Laboratory, 1986.

80. "Behavior of Fission Product Tellurium Under Severe Accident Conditions", J. L. Collins, M. F. Osborne, and R. A. Lorenz, Proceedings of the International ANS/ENS Topical Meeting on Thermal Reactor Safety, San Diego, CA, February 2-6, 1986, ANS Order No. 700106 (ISBN Order No.

0-89448-121-5), February 1986.

81. Design and Final Safety Analysis Report for Vertical Furnace Fission Product Release Apparatus in Hot Cell B, Building 4501, M. F. Osborne, J. L. Collins, P. A. Haas, R. A. Lorenz, J. R. Travis, and C. S. Webster, NUREG/CR-4332 (ORNL/TM-9270), Oak Ridge National Laboratory, March 1986.

82. Highlights Report for Fission Product Release Test VI-1, M. F. Osborne, J. L. Collins, R. A. Lorenz, and T. Yamashita, ORNL/NRC/LTR-86/7, Oak Ridge National Laboratory, March 1986.

83. Loss of Control Air at Browns Ferry Unit One-Accident Sequence Analysis, R. M. Harrington and S. A. Hodge, NUREG/CR-4413 (ORNL/TM-9826), Oak Ridge National Laboratory, April 1986.

84. "Calculational Support for the DF-4 Experiment in the ACRR", L. J. Ott, presented at the Severe Fuel Damage and Source Term Research Program Review Meeting, Oak Ridge, TN, April 1986.

85. "Effects of Lateral Separation of Oxidic and Metallic Core Debris on the BWR MK I Containment Drywell Floor", C. R. Hyman, C. F. Weber, and S. A. Hodge, Committee on Safety of Nuclear Installations (CSNI), Specialists Meeting on Core Debris/Concrete Interactions, EPRI NP-5054-SR, Palo Alto CA, September 3-5, 1986.

86. "Iodine Behavior in Containment Under LWR Accident Conditions", S. J. Wisbey, E. C. Beahm, W. E. Shockley, et al., Abstracts of Papers of the American Chemical Society, 192, pp. $92-$ NUCL (September 7, 1986).

87. "The Role of BWR MK I Secondary Containments in Severe Accident Mitigation", S. R. Greene and S. A. Hodge, in Transactions of the 14thWater Reactor Safety Information Meeting, Gaithersburg, MD, October 1986.

88. "Effects of Lateral Separation of Oxidic and Metallic Core Debris on the BWR MK I Containment Drywell Floor", C. R. Hyman and C. F. Weber, Trans. of 14th Water Reactor Safety Information Meeting, NUREG/CP-0081, U. S. Nuclear Regulatory Commission, Gaithersburg, MD, October 27-31, 1986.

89. "ORNL MELCOR BWR Assessment Efforts",S. R. Greene, presented at the MELCOR Users Group Meeting, October 31, 1986.

90. Thermal-Hydraulic and Characteristic Models for Packed Debris Beds, G. E. Mueller and A. Sozer, NUREG/CR-4689 (ORNL/TM-10117), Oak Ridge National Laboratory, December 1986.

91. Highlights Report for Fission Product Release Test VI-2, M. F. Osborne, J. L. Collins, R. A. Lorenz, and T. Yamashita, ORNL/NRC/LTR-86/18, Oak Ridge National Laboratory, December 1986. 
92. Response of the BWR Shroud Head Under Severe Accident Conditions, E. W. Barnes, M. Keyhani, and L. J. Ott, Letter Report to the BWRSAT Program NRC Technical Monitor (Dr. T. J. Walker, Accident Evaluation Branch, Division of Systems Research, RES USNRC), Oak Ridge National Laboratory, December 31, 1986.

93. "The Influence of Environment on Release Behavior and Chemical Forms of Fission Products Released Under LWR Accident Conditions", J. L. Collins, M. F. Osborne, and R. A. Lorenz, Proceedings of Workshop on Chemical Reactivity of Oxide Fuel and Fission Product Release, Berkeley, Gloucestershire, England, April 7-9, 1987.

94. "The Basic Chemistry Involved in the Internal-Gelation Method of Precipitating Uranium as Determined by $\mathrm{pH}$ Measurements", J. L. Collins, M. H. Lloyd, and R. L. Fellows, Radiochimica Acta, 42, pp. 121-134 (1987).

95. "Severe Core Damage and Associated In-Vessel Fission-Product Release", C. Allison, J. Rest, R. A. Lorenz, et al., Progress in Nuclear Energy, 20(2), pp. 89-132 (1987).

96. "Calculation of Absorbed Doses to Water Pools in Severe Accident Sequences", C. F. Weber, Trans. Am. Nucl. Soc., 55, pp. 367-368 (1987).

97. "Calculations of Iodine Source Terms in Support of NUREG-0956", E. C. Beahm, C. F. Weber, T. S. Kress, and R. J. Anderman, ORNL/NRC/LTR-86/17, Oak Ridge National Laboratory, 1987.

98. "Effects of Lateral Separation of Oxidic and Metallic Core Debris on the BWR MK I Containment Drywell Floor", C. R. Hyman and C. P. Weber, NUREG/CR-4610 (ORNL/TM10057), Oak Ridge National Laboratory, January 1987.

99. "Fission-Product Tellurium Release Behavior Under Severe Light-Water Reactor Accident Conditions", J. L. Collins, M. F. Osborne, and R. A. Lorenz, Nuclear Technology, 77(1), pp. 18 31 (April 1987).

100. "The Absorption of Gaseous Iodine by Water Droplets", M. F. Albert, J. S. Watson, and R. P. Wichner, Nuclear Technology, 77(2), pp. 161-174 (May 1987).

101. "Calculational Support for the DF-4 Experiment in the ACRR", L. J. Ott, presented at the Severe Fuel Damage, Containment Loads, and Source Term Research Program Review Meeting, Silver Spring, MD, May 4-8, 1987.

102. "The Release and Transport of Fission Product Cesium in the TMI-2 Accident", R. L. Lorenz and J. L. Collins, pp. 4-69-4-83 in the Proceedings of the Symposium on Chemical Phenomena Associated with Radioactivity Releases During Severe Nuclear Plant Accidents, Anaheim, CA, Sept. 9-12, 1986, also published as NUREG/CP-0078, June 1987.

103. "ORNL Severe Accident Analysis for $25 \%$ Power Operation at the Shoreham Nuclear Power Station", S. R. Greene and S. A. Hodge, Oak Ridge National Laboratory, June 18, 1987.

104. "An Assessment of the Shoreham Nuclear Power Station's Secondary Containment Severe Accident Mitigation Capability", S. R. Greene, ORNL LTR Report to U.S. Nuclear Regulatory Commission, June 26, 1987.

105. “Organic Iodide Formation During Severe Accidents in Light Water Nuclear-Reactors", E. C. Beahm, Y. M. Wang, S. J. Wisbey, et al., Nuclear Technology, 78(1), pp. 34-42 (July 1987). 
106. "Highlights Report for Fission Product Release Test VI-3", M. F. Osborne, J. L. Collins, R. A. Lorenz, J. R. Travis, C. S. Webster, S. R. Daish, H. K. Lee, T. Nakamura, and Y. C. Tong, draft letter report to SFD Partners, July 1987.

107. "Experimental Studies of Fission-Product Release from Commercial Light-Water Reactor Fuel Under Accident Conditions", M. F. Osborne, J. L. Collins, and R. A. Lorenz, Nuclear Technology, 78(2), pp. 157-169 (August 1987).

108. "Modeling of the Transport of Vapor Fission Product Species to Aerosols", T. S. Kress, E. C. Beahm, and C. F. Weber, presented at the Workshop on Water-Cooled Reactor Aerosol Code Evaluation and Uncertainty Assessment, Brussels, Belgium, September 9-11, 1987.

109. "The Impact of BWR MK I Primary Containment Failure Dynamics on Secondary Containment Integrity", S. R. Greene, in Transactions of the 15thWater Reactor Safety Information Meeting, Gaithersburg, MD, October 1987.

110. “Advanced Severe Accident Response Models for BWR Application", L. J. Ott, presented at the Severe Fuel Damage, Containment Loads, and Source Term Research Program Review Meeting, Silver Spring, MD, October 19-23, 1987.

111. "Advanced Severe Accident Response Models for BWR Application", L. J. Ott, presented at the Fifteenth Water Reactor Safety Research Information Meeting, Gaithersburg, MD, October 29, 1987.

112. "Fission Product Iodine and Cesium Release Behavior Under Severe LWR Accident Conditions", J. L. Collins, M. F. Osborne, R. A. Lorenz, and A. P. Malinauskas, Nucl. Technol. 81(10), pp. 7894 (November 1987).

113. "Calculation of Absorbed Doses to Water Pools in Severe Accident Sequences", C. F. Weber, presented at the Winter Meeting Am. Nucl. Soc., Los Angeles, CA, November 15-19, (1987).

114. "Considerations for Severe Accident Management Strategies in a Pressurized Water Reactor", J. J. Carbajo and J. C. Carter, Trans. Am. Nucl. Soc., 57, pp. 159-160 (1988).

115. "The Xenon Poisoning Problem Previous to the Chernobyl Accident", J. J. Carbajo, Trans. Am. Nucl. Soc., 56, pp. 404-405 (1988).

116. "Peach Bottom Containment Response Calculations for Unmitigated Short-Term Station Blackout", S. R. Greene, S. A. Hodge, C. R. Hyman, and L. J. Ott, Letter Report to the BWRSAT Program NRC Technical Monitor (Dr. T. J. Walker, Accident Evaluation Branch, Division of Systems Research, RES USNRC), Oak Ridge National Laboratory, February 1, 1988.

117. "Fission-Product Iodine and Cesium Release Behavior under Light Water-Reactor Accident Conditions", J. L. Collins, M. F. Osborne, R. A. Lorenz, et al., Nuclear Technology, 81(1), pp. 78-94 (April 1988).

118. "Proposed ORNL BWR Mark II Containment Response Considerations", S. R. Greene, presented to NRC Staff, April 21, 1988.

119. "Modeling of Time-Dependent Emergence of Core Debris from A Boiling Water Reactor Vessel Under Severe Accident Conditions", L. J. Ott and S. A. Hodge, Letter Report to the BWRSAT Program NRC Technical Monitor (Dr. T. J. Walker, Accident Evaluation Branch, Division of Systems Research, RES USNRC), Oak Ridge National Laboratory, April 22, 1988. 
120. "Small Scale BWR Core Debris Eutectics Formation and Melting Experiment-An Update", G. W. Parker, S. A. Hodge, and L. J. Ott, Letter Report to the BWRSAT Program NRC Technical Monitor (Dr. T. J. Walker, Accident Evaluation Branch, Division of Systems Research, RES USNRC), April 22, 1988.

121. "Separate Effects Melt Experiments", G. W. Parker, S. A. Hodge and L. J. Ott, presented at the Severe Accident Research Program Review Meeting, Albuquerque, NM, April 26, 1988.

122. "Primary Containment Response Calculations for Unmitigated Short-Term Station Blackout at Peach Bottom (with Consideration of (1) Separated Metal and Oxide Pours and (2) Degassing of Drywell Concrete)", S. A. Hodge, C. R. Hyman, and L. J. Ott, Letter Report to the BWRSAT Program NRC Technical Monitor (Dr. T. J. Walker, Accident Evaluation Branch, Division of Systems Research, RES USNRC), Oak Ridge National Laboratory, May 2, 1988.

123. "The Role of BWR Secondary Containments in Severe Accident Mitigation: Issues and Insights from Recent Analyses", S. R. Greene, in Proceedings of the 4th Workshop on Containment Integrity, Arlington, VA, NUREG/CR-0095, June 1988.

124. "Containment Venting as A Mitigation Technique for BWR MARK-1 Plant ATWS", R. M. Harrington, Nuclear Engineering and Design, 108(1-2), pp. 55-69 (June 1988).

125. "Iodine Behavior in Containment", E. C. Beahm, C. F. Weber, T. S. Kress, S. R. Daish, and W. E. Shockley, presented at the 2ndCSNI Workshop of Iodine Chemistry in Reactor Safety, Toronto, Canada, June 2-3, 1988.

126. "Chemistry and Mass Transport of Iodine in Containment", E. C. Beahm, C. F. Weber, T. S. Kress, W. E. Shockley, and S. R. Daish, presented at the Meeting Am. Chem. Soc., Toronto, Canada, June 4-9, 1988.

127. "Chemistry and Mass-Transport of Iodine in Containment", E. C. Beahm, C. F. Weber, T. S. Kress, et al., Abstracts of Papers of the American Chemical Society, 195, Part 2, pp. 101-NUCL (June 5, 1988).

128. "The Chemistry and Behavior of Iodine Vapor Species in Nuclear Plant Air-Monitoring Sampling Lines", A. L. Wright, B. R. Fish, E. C. Beahm, and C. F. Weber, presented at the 20th DOE/NRC Nuclear Air Cleaning Conf., Boston, MA, August 22-25, 1988.

129. "Trends Status", T. S. Kress, E. C. Beahm, W. E. Shockley, and C. F. Weber, presented at Severe Accident Research Program Review Meeting, Bethesda, MD, October 17-21, 1988.

130. "Experiment-Specific Codes for the DF-4 and NRU Experiments with BWR Geometries", L. J. Ott, presented at the Severe Accident Research Program Review Meeting, Bethesda, MD, October 17-21, 1988.

131. "BWRSAR Calculations of Reactor Vessel Debris Pours for Peach Bottom Short-Term Station Blackout", L. J. Ott and S. A. Hodge, presented at the Sixteenth Water Reactor Safety Research Information Meeting, Gaithersburg, MD, October 27, 1988.

132. "Small Scale BWR Core Debris Eutectics Formation and Melting Experiment", G. W. Parker, L. J. Ott, and S. A. Hodge, presented at the Sixteenth Water Reactor Safety Research Information Meeting, Gaithersburg, MD, October 27, 1988. 
133. "BWR Mark II and III Parametrics Program", S. R. Greene and S. A. Hodge, ORNL NRC Program Review for E. Beckjord, Director, Office of Research, U. S. Nuclear Regulatory Commission, November 9, 1988.

134. "Primary Containment Response Calculations for Unmitigated Short-Term Station Blackout at Peach Bottom (with Consideration of (1) Separated Metal and Oxide Pours, (2) Melting of Reactor Vessel Bottom Head, and (3) Degassing of Drywell Concrete", S. A. Hodge, C. R. Hyman, and L. J. Ott, Letter Report to the BWRSAT Program NRC Technical Monitor (Dr. T. J. Walker, Accident Evaluation Branch, Division of Systems Research, RES USNRC), Oak Ridge National Laboratory, November 28, 1988.

135. "Boiling Water Reactor Severe Accident Technology at Oak Ridge-Purpose and Goals", S. A. Hodge, C. R. Hyman, and L. J. Ott, Letter Report to the BWRSAT Program NRC Technical Monitor (Dr. T. J. Walker, Accident Evaluation Branch, Division of Systems Research, RES USNRC), Oak Ridge National Laboratory, December 6, 1988.

136. "Station Blackout Severe Accidents in APWRs", J. J. Carbajo, presented at the International Topical Meeting on Probability, Reliability, and Safety Assessment, PSA 1989, April 2-7, 1989, Pittsburgh, PA, 1989.

137. "Boiling Water Reactor Severe Accident Response (BWRSAR) Code Description and Assessment", S. A. Hodge and L. J. Ott, Letter Report to the BWRSAT Program NRC Technical Monitor, Oak Ridge National Laboratory, February 1, 1989.

138. "Primary Containment Response Calculations for Unmitigated Short-Term Station Blackout at Peach Bottom", S. A. Hodge, C. R. Hyman, and L. J. Ott, Letter Report to the BWRSAT Program NRC Technical Monitor, Oak Ridge National Laboratory (1989).

139. "Time-Dependent Release of Fission Products from LWR Fuel Under Severe Accident Conditions", M. F. Osborne, R. A. Lorenz, J. L. Collins, and T. Nakamura, Proceedings of International ENS/ANS Conference on Thermal Reactor Safety, Avignon, France, Oct. 3-7, 1988 [published October 1988 (Vols. 1-4) and March 1989 (Vols. 5-6)].

140. "Boiling Water Reactor Severe Accident Response (BWRSAR) Post-Test Analyses of the ACRR DF-4 Experiment", L. J. Ott, presented at the Severe Accident Research Program Review Meeting, Idaho Falls, ID, April 11, 1989.

141. "Failure Modes of the BWR Reactor Vessel Bottom Head", S. A. Hodge and L. J. Ott, ORNL/M1019 (Letter Report to the BWRSAT Program NRC Technical Monitor [Dr. T. J. Walker, Accident Evaluation Branch, Division of Systems Research, RES USNRC]), Oak Ridge National Laboratory, May 10, 1989.

142. "Iodine Behavior in Containment”, E. C. Beahm, C. F. Weber, T. S. Kress, and W. E. Shockley, presented at ICHMT Seminar on Fission Product Transport Processes in Reactor Accidents, Dubrovnik, Yugoslavia, May 22-26, 1989.

143. "TRENDS: A Code for Modeling Iodine Behavior in Containment During Severe Accidents", C. F. Weber, E. C. Beahm, T. S. Kress, S. R. Daish, and W. E. Shockley, in Proc. ICHMT Int. Seminar on Heat and Mass Transfer Aspects of Fission Product Releases, Dubrovnik, Yugoslavia, May 22-26, 1989. 
144. "Data Summary Report for Fission Product release Test VI-1", M. F. Osborne, J. L. Collins, R. A. Lorenz, J. R. Travis, C. S. Webster, and T. Yamashita, NUREG/CR-5339 (ORNL/TM-11104), Oak Ridge National Laboratory, June 1989.

145. “Advanced Severe Accident Response Models for BWR Application”, L. J. Ott, Nuclear Engineering and Design, 115(2-3), pp. 289-303 (July 1989).

146. "Post-Test Analyses of the DF-4 BWR Experiment Using the BWRSAR/DF4 Code", L. J. Ott, Letter Report to the BWRSAT Program NRC Technical Monitor (Dr. T. J. Walker, Accident Evaluation Branch, Division of Systems Research, RES USNRC), ORNL/M-1020, Oak Ridge National Laboratory, August 11, 1989.

147. "Data Summary Report for Fission Product release Test VI-2", M. F. Osborne, J. L. Collins, R. A. Lorenz, J. R. Travis, and C. S. Webster, NUREG/CR-5340 (ORNL/TM-11105), Oak Ridge National Laboratory, September 1989.

148. "BWR Severe Accident Experiment Needs", L. J. Ott, presented at the International CORA Workshop 1989, Karlsruhe, FRG, September 25-27, 1989.

149. "BWR Specific Effects in Severe Accident Behavior", L. J. Ott, presented at the International CORA Workshop 1989, Karlsruhe, FRG, September 25-27, 1989.

150. "Experiment-Specific BWR Code Analysis of the ACRR DF-4 Experiment",L. J. Ott, presented at the International CORA Workshop 1989, Karlsruhe, FRG, September 25-27, 1989.

151. "Description of the NRU FLHT-6 Experiment-Specific Code and Preliminary Pre-Test Predictions", L. J. Ott, Letter Report to the BWRSAT Program NRC Technical Monitor (Dr. T. J. Walker, Accident Evaluation Branch, Division of Systems Research, RES USNRC), ORNL/M1021, Oak Ridge National Laboratory, September 22, 1989.

152. "Thermophoretic Transport of Particles that Act as Volumetric Heat Sources in Natural Convection" Flow, J. C. Conklin and R. J. Krane, ORNL-6573, Oak Ridge National Laboratory, October 1989.

153. "The DF-4 Fuel Damage Experiment in ACRR With A BWR Control Blade and Channel Box", R. O. Gauntt, R. D. Gasser, and L. J. Ott, NUREG/CR-4671 (SAND-86-1443), Sandia National Laboratories, Albuquerque, NM, November 1989.

154. "Behavior of Iodine in Containment", E. C. Beahm, C. F. Weber, M. L. Brown, and W. E. Shockley Presentation, Oak Ridge National Laboratory, Oak Ridge, TN, December 5, 1989.

155. "The Response of BWR Mark II and Mark III Containments to Short-Term Station Blackout Severe Accident Sequences", S. R. Greene et al., ORNL/NRC/LTR-89/13, Oak Ridge National Laboratory, 1990.

156. "Small-Scale BWR Core Debris Eutectics Formation and Melting Experiment", G. W. Parker, L. J. Ott, and S. A. Hodge", Nuclear Engineering and Design, 121 (1990).

157. "BWRSAR Calculations of Reactor Vessel Debris Pours for Peach Bottom Short-Term Station Blackout", S. A. Hodge and L. J. Ott, Nuclear Engineering and Design, 121 (1990). 
158. "Debris Bed Behavior in the BWR Lower Plenum-The BWRSAR Approach with Recommended Improvements for Installation in MELCOR”, S. A. Hodge, ORNL/NRC/LTR90/10, Oak Ridge National Laboratory, April 26, 1990.

159. "BWR Experiment Analyses and Principal BWR Severe Accident Uncertainties", L. J. Ott, presented at the Severe Accident Research Program Partners Review Meeting, Brookhaven National Laboratory, Upton, NY, May 1, 1990.

160. "Boiling Water Reactor Severe Accident Models for MELCOR", S. A. Hodge, ORNL/NRC/LTR-90/13, Oak Ridge National Laboratory, May 22, 1990.

161. "Data Summary Report for Fission Product Release Test VI-3", M. F. Osborne, R. A. Lorenz, J. L. Collins, J. R. Travis, C. S. Webster, H. K. Lee, T. Nakamura, and Y.-C. Tong, NUREG/CR5480 (ORNL/TM-11399), Oak Ridge National Laboratory, June 1990.

162. "Fission Product Release from Commercial vs. Simulated Fuels in LWR Accident Studies", M. F. Osborne, H. Albrecht, R. A. Lorenz, and J. L. Collins, presented at the 1990 Annual Meeting of the American Nuclear Society, Nashville, TN, June 10-14, 1990; summary published in Trans. ANS Annl. Mtg., 61, pp. 251-52, American Nuclear Society (June 1990).

163. "The Role of BWR Secondary Containments in Severe Accident Mitigation: Issues and Insights from Recent Analyses", S. R. Greene, Nuclear Engineering and Design, 120(1), pp. 75-86 (June 1, 1990).

164. "A Survey of Current Models of BWR Core Plate Failure Used in the Severe-Accident Codes APRIL, BWRSAR, MELCOR, MELPROG, and SCDAP/RELAP”, L. J. Ott and W. I. Van Rij, Letter Report to the BWRCMP Program NRC Technical Monitor (Dr. R. W. Wright, Accident Evaluation Branch, Division of Systems Research, RES USNRC), ORNL/NRC/LTR-90/14, Oak Ridge National Laboratory, June 29, 1990.

165. "Kinetic Modeling and Parameter Optimization of Iodine Hydrolysis Reactions", C. F. Weber, M.S. Thesis, University of Tennessee, August 1990.

166. "BWRSAR Calculations of Reactor Vessel Debris Pours for Peach Bottom Sort-Term Station Blackout", S. A. Hodge and L. J. Ott, Nuclear Engineering and Design, 121(3), pp. 327-339 (August 1990).

167. "Small-Scale BWR Core Debris Eutectics Formation and Melting Experiment", G. W. Parker, L. J. Ott, and S. A. Hodge, Nuclear Engineering and Design, 121(3), pp. 341-347 (August 1990).

168. "Contain Calculations of Debris Conditions Adjacent to the BWR MARK-1 Drywell Shell During the Later Phases of a Severe Accident", C. R. Hyman, Nuclear Engineering and Design, 121(3), pp. 379-393 (August 1990).

169. "Experiment-Specific BWR Code Analysis of the CORA-17 Experiment", L. J. Ott, presented at the International CORA Workshop 1990, Karlsruhe, Germany, September 28-October 2, 1990.

170. "Post-Test Analyses of the CORA-16 Experiment", L. J. Ott, presented at the International CORA Workshop 1990, Karlsruhe, Germany, September 28-October 2, 1990.

171. "A Survey of Current Models of BWR Lower Head Failure Used in the Severe-Accident Codes APRIL, BWRSAR, MELCOR, MELPROG, and SCDAP/RELAP”, L. J. Ott and W. I. Van Rij, Letter Report to the BWRCMP Program NRC Technical Monitor (Dr. R. W. Wright, Accident 
Evaluation Branch, Division of Systems Research, RES USNRC), ORNL/NRC/LTR-90/26, Oak Ridge National Laboratory, September 30, 1990.

172. "Description of the CORA BWR Experiment-Specific Code", L. J. Ott, Letter Report to the BWRCMP Program NRC Technical Monitor (Dr. R. W. Wright, Accident Evaluation Branch, Division of Systems Research, RES USNRC), ORNL/NRC/LTR-90/23, Oak Ridge National Laboratory, September 30, 1990.

173. "Post-Test Analyses of CORA BWR Experiments", L. J. Ott, Letter Report to the BWRCMP Program NRC Technical Monitor (Dr. R. W. Wright, Accident Evaluation Branch, Division of Systems Research, RES USNRC), ORNL/NRC/LTR-90/24, Oak Ridge National Laboratory, September 30, 1990.

174. "Results of Recent ORNL Fission Product Release Tests", R. A. Lorenz, M. F. Osborne, and J. L. Collins, presented at the 18th Water Reactor Safety Meeting at Rockville, MD, October 22-24, 1990.

175. "Experiment-Specific Analyses in Support of Code Development", L. J. Ott, presented at the Eighteenth Water Reactor Safety Research Information Meeting, Rockville, MD, October 23, 1990.

176. "Effect of an In-Containment Refueling Water Storage Tank on Station Blackout Accidents", J. J. Carbajo, Trans. Am. Nucl. Soc., 63, pp. 311-313 (1991).

177. "In-Vessel Hydrogen Generation During Station Blackout Severe Accident Sequences in APWRs", J. J. Carbajo, Trans. Am. Nucl. Soc., 63, pp. 313-314 (1991).

178. "In-Vessel Hydrogen Generation During a Station Blackout Severe Accident”, J. J. Carbajo, Trans. Am. Nucl. Soc., 63, pp. 327-328 (1991).

179. "Direct Containment Heating Calculations for the Zion Plant", J. J. Carbajo, Trans. Am. Nucl. Soc., 63, pp. 328-329 (1991).

180. "Characterization of Debris/Concrete Interactions for Advanced Research Reactor and Commercial BWR Severe Accidents",C. R. Hyman, R. P. Taleyarkhan, and S. R. Greene, in Proceedings for the American Nuclear Society Winter Meeting, (1991).

181. "Severe LWR Accident Studies of Fission Product Release and Fuel Behavior at ORNL", M. F. Osborne, R. L. Lorenz, and J. L. Collins, presented at the 15th Nuclear Safety Research Reactor Technical Review Meeting, Washington, DC, 1991.

182. "Characterization of Debris/Concrete Interactions for Commercial BWR Mark II and Research Reactors Severe Accidents", C. R. Hyman, R. P. Taleyarkhan, and S. R. Greene, presented at the National Heat Transfer Conference, Minneapolis, MN, 1991.

183. "Calculation of Absorbed Doses to Water Pools in Severe Accident Sequences", C. F. Weber, ORNL/TM-11970, Oak Ridge National Laboratory, 1991.

184. "Data Summary Report for Fission Product Release Test VI-4", M. F. Osborne, R. A. Lorenz, J. L. Collins, J. R. Travis, C. S. Webster, and T. Nakamura, NUREG/CR-5481 (ORNL/TM-11400), Oak Ridge National Laboratory, January 1991. 
185. "Identification and Initial Assessment of BWR In-Vessel Accident Management Strategies", S. A. Hodge, presented at Accident Management Information Exchange Meeting USNRCBMU/GRS, April 15, 1991.

186. "In-Vessel Phenomena-CORA", L. J. Ott and W. I. van Rij, presented at the Cooperative Severe Accident Research Program (CSARP) Semiannual Review Meeting, Bethesda, MD, May 7, 1991.

187. "The Response of BWR Mark III Containments to Short-Term Station Blackout Severe Accident Sequences", S. R. Greene, S. A. Hodge, C. R. Hyman, B. W. Patton, and M. L. Tobias, NUREG/CR-5571 (ORNL/TM-11549), Oak Ridge National Laboratory, June 1991.

188. "Fission Product Behavior", T. S. Kress, E. C. Beahm, and C. F. Weber, presented at the Annual Meeting American Nuclear Society, Orlando, FL, June 2-6, 1991; also published in Trans. Amer. Nucl. Soc., 63, pp. 260 (1991).

189. "CCCTF Shakedown Tests", Draft, R. N. Morris, J. L. Collins, W. A. Gabbard, J. C. Whitson, and M. F. Osborne, July 1991.

190. "Atmospheric Effects on Fission Product Behavior at Severe Accident Conditions", M. F. Osborne, R. A. Lorenz, and J. L. Collins, in Proceedings of the American Nuclear Society International Topical Meeting on the Safety of Thermal Reactors, Portland, OR, (July 21-25, 1991).

191. "Significant BWR Technical Developments from the CORA Program", L. J. Ott, Letter Report to the BWRCMP Program NRC Technical Monitor (Dr. R. W. Wright, Accident Evaluation Branch, Division of Systems Research, RES USNRC), ORNL/NRC/LTR-91/14, Oak Ridge National Laboratory, July 31, 1991.

192. "Report of Foreign Travel by C. F. Weber", September 7-15, 1991, C. F. Weber, ORNL/CSD/FTR-4049, Oak Ridge National Laboratory, September 1991.

193. "Data Summary Report for Fission Product Release Test VI-5", M. F. Osborne, R. A. Lorenz, J. R. Travis, C. S. Webster, and J. L. Collins, ORNL/CR-5668 (ORNL/TM-11743), Oak Ridge National Laboratory, September 1991.

194. "Iodine Chemical Forms in LWR Severe Accidents", C. F. Weber, E. C. Beahm, and T. S. Kress, presented at the 3rd Committee for Safety in Nuclear Installations Workshop on Iodine Chemistry in Reactor Safety, Tokai-mura, Japan, September 11-13, 1991.

195. "Iodine Chemical Forms in LWR Accidents: Preliminary Presentation of Results", E. C. Beahm, C. F. Weber, and T. S. Kress, presented at Committee for Safety in Nuclear Installations Iodine Specialists'Meeting, Shinhara, Mito-Shi, Japan, September 11-13, 1991; also in Nucl. Technol., 101, pp. 262-269 (1993).

196. "Current Status of the Experimental Data and Phenomenological Modeling in BWR Core Melt Progression", L. J. Ott and W. I. Van Rij, Letter Report to the BWRCMP Program NRC Technical Monitor (Dr. Ali Behbahani, Accident Evaluation Branch, Division of Systems Research, RES USNRC), ORNL/NRC/LTR-91/16, Oak Ridge National Laboratory, September 31, 1991.

197. “Assessment of Two BWR Accident Management Strategies", S. A. Hodge and M. Petek, in CONF-911079-2, October 1991. 
198. "BWR Lower Plenum Debris Bed Models for MELCOR", S. A. Hodge and L. J. Ott, presented at the Nineteenth Water Reactor Safety Research Information Meeting, Bethesda, MD, October 2830, 1991.

199. "Iodine Chemical Forms in LWR Severe Accidents", E. C. Beahm, C. F. Weber, T. S. Kress, and G. W. Parker, in Proceedings of the 19th Water Reactor Safety Information Meeting, 2, pp. 325342, Bethesda, MD, October 28-30, 1991.

200. "BWR Mark II Ex-Vessel Corium Interaction Analyses", S. R. Greene, A. E. Levin, C. R. Hyman, A. Sozer, and R. P. Taleyarkhan, NUREG/CR-5623 (ORNL/TM-11644), Oak Ridge National Laboratory, November 1991.

201. "ORNL Studies of Fission Product Release Under LWR Accident Conditions", F. F. Osborne, R. A. Lorenz, and J. L. Collins, presented at the Second Workshop on LWR Severe Accident Research A JERI, Tokoyo, Japan, November 25-27, 1991(also published in the proceedings of the meeting). 1992

202. "Spent-Fuel Decay Heat and Source Term Uncertainties", J. J. Carbajo, Trans. Am. Nucl. Society, 65, pp. 66-67(1992).

203. "Effect of the Timing of Vessel Depressurization on a Short-Term Station Blackout in a BWR-4 Performed with the MELCOR Code", J. J. Carbajo, Trans. Am. Nucl. Society, 66, pp. 327-328 (1992).

204. "The Core Conduction Cooldown Test Facility: Current Status and Issues", R. N. Morris, C. A. Baldwin, J. L. Collins, L. C. Emerson, W. A. Gabbard, C. M. Malone, B. F. Myers, M. F. Osborne, M. L. Peters, J. C. Whitson, and J. L. Wright, ORNL/NRP-91/7, Oak Ridge National Laboratory, January 1992.

205. "Core Conduction Cooldown Test Facility Shakedown Tests", R. N. Morris, J. L. Collins, W. A. Gabbard, and J. C. Whitson, ORNL/NRP-91/25, Oak Ridge National Laboratory, May 1992.

206. "HRB-17 and HRB-18 HEU TRISO UCO Unbonded Irradiated Particle Core Conduction Cooldown Tests", R. N. Morris, C. A. Baldwin, J. L. Collins, C. M. Malone, W. A. Gabbard, J. R. Travis, C. S. Webster, J. C. Whitson, J. L. Wright, and M. J. Kania, ORNL/NRP-92/9, Oak Ridge National Laboratory, June 1992.

207. "Iodine Chemical Forms in LWR Severe Accidents", Final Report, E. C. Beahm, C. F. Weber, T. S. Kress, and G. W. Parker, ORNL/TM-11861 (NUREG/CP-0119), Oak Ridge National Laboratory, 1992.

208. "Iodine Evolution and pH Control", E. C. Beahm, R. A. Lorenz, and C. F. Weber, ORNL/TM12242, Oak Ridge National Laboratory, 1992.

209. "Models of Iodine Behavior in Reactor Containments", E. C. Beahm, C. F. Weber, T. S. Kress, and G. W. Parker, ORNL/TM-12202, Oak Ridge National Laboratory, 1992.

210. "MELCOR Modifications for SBWR Applications", C. R. Hyman, R. L. Sanders, S. R. Greene, and S. A. Hodge, in Proceedings of the Twentieth Water Reactor Safety Information Meeting, Bethesda, MD, (1992).

211. "Optimal Determination of Rate Coefficients in Multiple Reactor Systems", C. F. Weber, E. C. Beahm, and J. S. Watson, Comput. Chem., 16(4), pp. 325-333 (1992). 
212. "Iodine Chemical Forms in LWR Severe Accidents", E. C. Beahm and C. F. Weber, presentation to Advisory Committee Reactor Safeguards (ACRS), Bethesda, MD, January 7-8, 1992.

213. "BWR Core Melt Progression Phenomena - Experimental Analyses",L. J. Ott, presented at the Cooperative Severe Accident Research Program (CSARP) Review Meeting, Bethesda, MD, May 4-8, 1992.

214. "Iodine Transport in Containment", E. C. Beahm, C. F. Weber, and T. S. Kress, presented at Cooperative Severe Accident Research Program (CSARP) Meeting, Bethesda, MD, May 4-8, 1992.

215. "An Assessment of MELCOR Modeling Modifications Required for the Simplified Boiling Water Reactor", S. R. Greene, S. A. Hodge, C. R. Hyman, and R. L. Sanders, ORNL/NRC/LTR92/11, Oak Ridge National Laboratory, May 29, 1992.

216. "BWR Control Blade/Channel Box Interaction and Melt Relocation Models for SCDAP", F. P. Griffin, ORNL/NRC/LTR-92/12, Oak Ridge National Laboratory, June 15, 1992.

217. "Post-Test Analysis of the CORA-16 and CORA 17 BWR Experiments", L. J. Ott, ORNL/NRC/LTR-92/17, Oak Ridge National Laboratory, July 10, 1992.

218. "ORNL Studies of Fission-Product Release Under LWR Severe Accident Conditions", M. F. Osborne and R. A. Lorenz, Nuclear Safety, 33(3), pp. 344-365 (July-September 1992).

219. "Iodine Chemical Forms in LWR Severe Accidents", C. F. Weber, E. C. Beahm, and T. S. Kress, pp. 414-430 in Proc. 3rd CSNI Workshop on Iodine Chemistry in Reactor Safety, Tokai-mura, Japan, September 11-13, 1992, NEA/CSNI/R 91,15, JAERI, 1992.

220. "An Assessment of SCDAP/RELAP5 Modeling Modifications Required for the Simplified Boiling" Water Reactor, F. P. Griffin, ORNL/NRC/LTR-92/25, Oak Ridge National Laboratory, September 30, 1992.

221. "Thermal Shock Considerations for External Flooding of A BWR Reactor Vessel”, S. A. Hodge and W. J. McAfee, ORNL/NRC/LTR-92-23, Oak Ridge National Laboratory, September 30, 1992.

222. "Identification and Assessment of BWR In-Vessel Severe Accident Mitigation Strategies", S. A. Hodge, J. C. Cleveland, T. S. Kress, and M. Petek, NUREG/CR-5869 (ORNL/TM-12080), Oak Ridge National Laboratory, October 1992; also published in CONF-921007-31, October 1992.

223. "ORNL Pre- and Post-Test Analyses of BWR Experiments", L. J. Ott, presented at the International CORA Workshop 1992, Karlsruhe, Germany, October 6, 1992.

224. "Core Melt Source Reduction System (COMSORS) for Light-Water Reactors" (Draft), presented at COMSORS Program Review Meeting, Tenera Bethesda Office, Bethesda, MD, October 20, 1992.

225. "Report of Foreign Travel to KfK", Germany and Participation in the CORA-33 Experiment, L. J. Ott, letter report to the BWRCMP Program NRC Technical Monitor (Dr. Ali Behbahani, Accident Evaluation Branch, Division of Systems Research, RES USNRC), ORNL/NRC/LTR92/28, November 20, 1992. 
226. "BWR Control Blade/Channel Box Interaction and Melt Relocation Models for SCDAP", Revision 1, F. P. Griffin and K. A. Smith, ORNL/NRC/LTR-92/12/R1, Oak Ridge National Laboratory, December 31, 1992.

227. "Post-Test Analyses of the CORA-31 Slow Heatup BWR Experiment", L. J. Ott, ORNL/NRC/LTR-92/29, Oak Ridge National Laboratory, December 31, 1992.

228. "Iodine Evolution and pH Control", E. C. Beahm, R. A. Lorenz, and C. F. Weber, Trans. Am. Nucl. Soc., 59, pp. 387 (1993).

229. "Iodine Transport in a Severe Accident at the High Flux Isotope Reactor", C. F. Weber and E. C. Beahm, Trans. Amer. Nucl. Soc., 68A, p. 275 (1993).

230. "MELCOR Simulation of a Large-Break LOCA at the High Flux Isotope Reactor", R. H. Morris, S. E. Fisher, and S. R. Greene, in CONF-930601, Transactions of the American Nuclear Society, 68(1993).

231. "Severe Accident Source Term Characteristics for Selected Peach Bottom Sequences Predicted by the MELCOR Code", J. J. Carbajo, NUREG/CR-5942 (ORNL/TM-12229), Oak Ridge National Laboratory, 1993.

232. "Vessel Failure Time for a Low-Pressure Short-Term Station Blackout in a BWR-4", J. J. Carbajo, Trans. Am. Nucl. Society, 67, pp. 306-307 (1993).

233. "MELCOR Code Analysis of a Severe Accident LOCA at Peach Bottom Plant", J. J. Carbajo, Trans. Am. Nucl. Society, 69, pp. 319-321 (1993).

234. "Containment Failure Time and Mode for a Low-Pressure Short-Term Station Blackout in a BWR-4 with Mark-I Containment", J. J. Carbajo and S. R. Greene, Trans. Am. Nucl. Society, 69, pp. 325-326 (1993).

235. "MELCOR 1.8.2 Assessment: Comparison of Fuel Fission Product Release Models to ORNL Vifuel Fission Product Release Experiment", S. R. Greene et al., ORNL/NRC/LTR-94/34, Oak Ridge National Laboratory, 1993.

236. "Fission-Product Transport Behavior", T. S. Kress, E. C. Beahm, C. F. Weber, and G. W. Parker, Nuclear Technology, 101(3), pp. 262-269 (March 1993).

237. "Iodine Transport Models for LWR Accidents", C. F. Weber and E. C. Beahm, in Cooperative Severe Accident Research Program Meeting (CSARP), Bethesda, MD, May 7, 1993.

238. "Iodine Transport in a Severe Accident at the High Flux Isotope Reactor", C. F. Weber and E. C. Beahm, Annual Meeting Am. Nucl. Soc., (1993).

239. "Current Status of BWR Experimental Analyses and the Need for Additional BWR Experiments”, L. J. Ott, ORNL/NRC/LTR-93/12, Oak Ridge National Laboratory, June 30, 1993.

240. "Post-Test Analyses of the CORA-33 Dry Core BWR Experiment", L. J. Ott, ORNL/NRC/LTR93/21, Oak Ridge National Laboratory, August 31, 1993.

241. "Post-Test Analyses of the CORA-28 Preoxidized BWR Experiment", L. J. Ott, ORNL/NRC/LTR-93/21, Oak Ridge National Laboratory, August 31, 1993. 
242. "Analysis and Interpretation of the Results of the CORA-33 Dry Core BWR Experiment", L. J. Ott, presented at the International CORA Workshop 1993, Karlsruhe, Germany, September 27, 1993.

243. "BWR Control Blade/Channel Box Interaction Models for SCDAP/RELAP5", F. P. Griffin, presented at the 21st Water Reactor Safety Research Information Meeting, Bethesda, MD, October 25-27, 1993.

244. "Interpretation of the Results of the CORA-33 Dry Core BWR Test", L. J. Ott and S. Hagen, presented at the 21st Water Reactor Safety Research Information Meeting, Bethesda, MD, October 25-27, 1993.

245. "Containment Failure Time and Mode for a Low-Pressure Short-Term Station Blackout in a BWR-4 with Mark-III Containment", S. R. Greene, in Proceedings of the American Nuclear Society Winter Meeting, San Francisco, CA, November (1993).

246. "Current Status of ORNL FLHT-6 Experimental Analyses", L. J. Ott and K. A. Smith, ORNL/NRC/LTR-93/30, Oak Ridge National Laboratory, November 30, 1993.

247. "Iodine Evolution and pH Control", E. C. Beahm, R. A. Lorenz, and C. F. Weber, in Proceedings of the Winter Meeting of the American Nuclear Society, San Francisco, CA, (November 14-18, 1993).

248. "Status of ORNL XR Experimental Analyses", L. J. Ott, ORNL/NRC/LTR-93/34, Oak Ridge National Laboratory, December 30, 1993.

249. "BWR Control Blade/Channel Box Interaction and Melt Relocation Models for SCDAP", Revision 2, F. P. Griffin, ORNL/NRC/LTR-92/12/R2, Oak Ridge National Laboratory, December 30, 1993.

250. "Optimum Depressurization for a Short-Term Station Blackout in a BWR-6 with High Burnup Fuel”, J. J. Carbajo, Trans. Am. Nucl. Society, 71, pp. 324-326 (1994).

251. "MELCOR Sensitivity Studies for a Low-Pressure, Short-Term Station Blackout at the Peach Bottom Plant”, J. J. Carbajo, Nucl. Eng. and Des., 152, pp. 287-317 (1994).

252. "Data Summary Report for Fission Product Release Test VI-6", M. F. Osborne, R. A. Lorenz, J. R. Travis, C. S. Webster, and J. L. Collins, ORNL/CR-6077 (ORNL/TM-12416), Oak Ridge National Laboratory, March 1994.

253. "Assessment of 2 BWR Accident Management Strategies", S. A. Hodge and M. Petek, Nuclear Engineering and Design, 148(2-3), pp. 185-203 (July 1994).

254. "Detailed Analysis of the BWR Dry Core Conditions for the XR2 Experiments", L. J. Ott and F. P. Griffin, presented at the International CORA Workshop 1994, Karlsruhe, Germany, October 10-12,1994.

255. "Development of the BWR Dry Core Initial and Boundary Conditions for the SNL XR2 Experiments", L. J. Ott and F. P. Griffin, ORNL/NRC/LTR-94/38, Oak Ridge National Laboratory, October 31, 1994.

256. "MELCOR Calculations for a Low-Pressure, Short-Term Station Blackout in a BWR-6", J. J. Carbajo, Trans. Am. Nucl. Society, 72, pp. 250-252 (1995). 
257. "Recovery Sequences for a Station Blackout Accident at the Grand Gulf Nuclear Station", J. J. Carbajo, Trans. Am. Nucl. Society, 72, pp. 226-228 (1995).

258. "Source Terms Released into the Environment for a Station Blackout Severe Accident at the Peach Bottom Atomic Power Station”, J. J. Carbajo, Proc. Topical Meeting on Safety of Operating Reactors, pp. 259-266 (1995).

259. "Comparison of MELCOR and SCDAP/RELAP5 Results for a Low-Pressure, Short-Term Station Blackout at Browns Ferry", J. J. Carbajo, Trans. Am. Nucl. Society, 73, pp. 259-269 (1995).

260. "Comparison of MELCOR Modeling Techniques and Effects of Vessel Water Injection on a Low-Pressure, Short-Term Station Blackout at the Grand Gulf Nuclear Station”, J. J. Carbajo, ORNL/TM-12771, Oak Ridge National Laboratory, 1995.

261. "Comparison of MELCOR Results, Including Parametric Variations, to SCDAP/RELAP5 Results for a Station Blackout Accident at Browns Ferry", J. J. Carbajo, ORNL/NRC/LTR-95/25, Oak Ridge National Laboratory, 1995.

262. "Description of the XR/BWR Experiment-Specific Code and Preliminary Post-Test Analyses of the XR1 Tests", L. J. Ott, ORNL/NRC/LTR-95/5, Oak Ridge National Laboratory, February 28, 1995.

263. "BWR Control Blade/Channel Box Interaction and Melt Relocation Models for SCDAP" (Revision 3), F. P. Griffin, ORNL/NRC/LTR-92/12/R3, Oak Ridge National Laboratory, March 31, 1995.

264. "Data Summary Report for Fission Product Release Test VI-7", M. F. Osborne, R. A. Lorenz, J. R. Travis, J. L. Collins, and C. S. Webster, NUREG/CR-6318 (ORNL/TM-12937), Oak Ridge National Laboratory, May 1995.

265. "Recent SCDAP/RELAP5 Improvements for BWR Severe Accident Simulations", F. P. Griffin, presented at the 23rd Water Reactor Safety Information Meeting, Bethesda, MD, October 23-25, 1995.

266. "Initial Development of an Upper Plenum Structure Degradation Model for SCDAP/RELAP5", F. P. Griffin, ORNL/NRC/LTR-95/31, Oak Ridge National Laboratory, October 31, 1995.

267. "In-Vessel Core Degradation Code Validation Matrix", T. J. Haste, L. J. Ott, et al., OCDE/GD 96 p.14, Committee on the Safety of Nuclear Installations, OECD Nuclear Energy Agency, (1996).

268. "Comparison of HASCAL and MELCOR Source Terms", J. J. Carbajo, Trans. Am. Nucl. Society, 75, pp. 271-73 (1996).

269. "MELCOR Calculated In-Containment Source Terms Using Different Release Models", J. J. Carbajo, Trans. Am. Nucl. Society, 74, pp. 252-253 (1996).

270. “Assessment of the RN and BH Packages of MELCOR 1.8.3", J. J. Carbajo, ORNL/NRC/LTR96/01, Oak Ridge National Laboratory, 1996. 
271. "BWR Control Blade/Channel Box Model for SCDAP/RELAP5: Damage Progression Theory and User Guide”, F. P. Griffin, ORNL/NRC/LTR-96/20, Oak Ridge National Laboratory, July $12,1996$.

272. "Interpretation of the Results of the CORA-33 Dry Core Boiling Water Reactor Test", L. J. Ott and S. Hagen, Nuclear Engineering and Design, 167, pp. 387-306 (1997).

273. "Severe Accident Sequences Analyzed for a Two-Loop PWR", J. J. Carbajo, Trans. Am. Nucl. Society, 77, pp. 259-260 (1997).

274. "MELCOR-Calculated In-Containment Source Terms With and Without the BH Package", J. J. Carbajo, Trans. Am. Nucl. Society, 77, pp. 290-292 (1997).

275. "Modeling the Chernobyl Accident with the HASCAL Code", J. J. Carbajo, Trans. Am. Nucl. Society, 76, pp. 273-275 (1997).

276. "Modeling the TMI-2 Accident with the HASCAL Code", J. J. Carbajo, Trans. Am. Nucl. Society, 76, pp. 275-277 (1997).

277. "Simulation of the PHEBUS FPT-1 Test with the MELCOR Code", J. J. Carbajo, ORNL/NRC/LTR-97/03, Oak Ridge National Laboratory, 1997.

278. "Validation of SCDAP/RELAP5 Against CORA BWR Test Results", F. P. Griffin, ORNL/NRC/LTR-97/1, Oak Ridge National Laboratory, February 28, 1997.

279. "SCDAP/RELAP5 Mod 3.2 Simulations for the Browns Ferry BWR Design", F. P. Griffin, ORNL/NRC/LTR-97/27, Oak Ridge National Laboratory, December 16, 1997.

280. "Interpretation of the XR2-1 Experiment and Characteristics of the BWR Lower Plenum Debris Bed", S. A. Hodge and L. J. Ott, presented at the Second International Conference on Advanced Reactor Safety (ARS'97), Orlando, FL, June 1-4, 1997.

281. "Applicability of BWR SFD Experiments and Codes for Advanced Core Component Designs", L. J. Ott, presented at the Technical Session on Thermal Hydraulics of Severe Accidents at the ANS Winter Annual Meeting, Albuquerque, NM, November 1997.

282. "SCDAP/RELAP5 MOD 3.2 Simulation for the Browns Ferry BWR Design", F. P. Griffin, ORNL/NRC/LTR-97/27, Oak Ridge National Laboratory, December 16, 1997.

283. "Accident Sequences Simulated at the Juragua Nuclear Power Plant", J. J. Carbajo, pp. 213-220 in Proc. of the International Topical Meeting on Safety of Operating Reactors, San Francisco, CA, (1998).

284. "Severe Accident Sequences Simulated at a VVER 440-213", J. J. Carbajo, Trans. Am. Nucl. Society, 78, pp. 198-199 (1998).

285. "Technical Assistance in Review of Source Term-Related Issues of Advanced Reactors", E. C. Beahm, C. F. Weber, and T. A. Dillow, ORNL/TM-13144, Oak Ridge National Laboratory, 1998.

286. "Iodine Volatility and pH Control in the AP-600 Reactor", C. F. Weber and E. C. Beahm, ORNL/TM-13555, Oak Ridge National Laboratory, 1998. 
287. "SCDAP/RELAP5 Modifications for New BWR Control Blade Designs", F. P. Griffin, ORNL/NRC/LTR-98/18, Oak Ridge National Laboratory, September 30, 1998.

288. “MELCOR Small Break LOCA Calculations", J. J. Carbajo, ORNL/NRC/LTR-98/21, Oak Ridge National Laboratory, 1999.

289. “MELCOR DBA LOCA Calculations”, J. J. Carbajo, ORNL/NRC/LTR-97/21, Oak Ridge National Laboratory, 1999.

290. "Severe Accident Sequences Simulated at the Grand Gulf Nuclear Station", J. J. Carbajo, Trans. Am. Nucl. Society, 80, pp. 174-176 (1999).

291. "Iodine Revolatizitation in a Grand Gulf LOCA", C. F. Weber and E. C. Beahm, ORNL/M-6544, Oak Ridge National Laboratory, 1999.

292. "SCDAP/RELAP5 Lower Core Plate Model”, E. W. Coryell and F. P. Griffin, INEEL/EXT-9901029, Final Design Report, September 1999.

293. "Review of Grand Gulf Methodology and Calculations for pH Control and Iodine Volatility", C. F. Weber, Letter Report to USNRC, ORNL/NRC/LTR-00/07, Oak Ridge National Laboratory, 2000 .

294. "Fission Product and Chemical Speciation Test Plan and Cost Estimate", D. D. Lee, J. L. Collins, B. E Lewis, J. L. Binder, S. C. Marschman, C. F. Weber, and R. N. Morris, Oak Ridge National Laboratory (February 28, 2005).

295. "A Review and an Analysis of the ORNL and Chalk River Fission Product Release Tests and Their Relevance to Hypothetical Loss-of-Coolant Spent-Fuel Storage Pool Accidents”, J. L. Collins and J. L. Binder, ORNL/TM-2004/20, Oak Ridge National Laboratory, April 2005.

296. "Spray Sensitivity Study Performed with the MELCOR Code", J. J. Carbajo and A. Drozd, Trans. Am. Nucl. Society, 102, pp. 324-326 (June 2010). 
APPENDIX B-TABLE 5 AND TABLE 6 FROM NUREG/CR-5444: SUMMARY OF INSTRUMENT AVAILABILITY 

Table 5. Summary of instrument availability.

Category 1

A Instrument Available

Degraded Performance Possible

\begin{tabular}{|c|c|c|c|c|c|c|}
\hline Plant instrumentation & $\begin{array}{c}\text { Safety } \\
\text { functions }\end{array}$ & $\begin{array}{l}\text { Severe } \\
\text { conditions only } \\
\text { in reactor } \\
\text { system }\end{array}$ & $\begin{array}{c}\text { Severe } \\
\text { containment } \\
\text { conditions } \\
\text { before core } \\
\text { damage }\end{array}$ & $\begin{array}{l}\text { Severe } \\
\text { containment } \\
\text { conditions } \\
\text { after core } \\
\text { damage }\end{array}$ & $\begin{array}{l}\text { Severe reactor } \\
\text { building } \\
\text { conditions } \\
\text { before core } \\
\text { damage }\end{array}$ & $\begin{array}{c}\text { Severe } \\
\text { reactor } \\
\text { building } \\
\text { conditions } \\
\text { after core } \\
\text { damage }\end{array}$ \\
\hline Reactor pressure & $\begin{array}{l}\mathrm{V} 1, \mathrm{~V} 2, \mathrm{~V} 3, \\
\mathrm{~V} 4, \mathrm{C} 2\end{array}$ & A & A & A & & \\
\hline Reactor water level & $\mathrm{V} 2, \mathrm{~V} 3, \mathrm{~V} 4, \mathrm{C} 1$ & A & A & A & & \\
\hline Source range monitor & $\mathrm{V} 2$ & & & & & \\
\hline $\begin{array}{l}\text { Average power } \\
\text { range monitor }\end{array}$ & $\mathrm{V} 2$ & & & & & \\
\hline
\end{tabular}


Table 5. (continued).

Category 1 (continued)

\begin{tabular}{|c|c|c|c|c|c|c|}
\hline Plant instrumentation & $\begin{array}{l}\text { Safety }{ }^{\mathrm{a}} \\
\text { functions }\end{array}$ & $\begin{array}{c}\text { Severe } \\
\text { conditions only } \\
\text { in reactor } \\
\text { system }\end{array}$ & $\begin{array}{c}\text { Severe } \\
\text { containment } \\
\text { conditions } \\
\text { before core } \\
\text { damage }\end{array}$ & $\begin{array}{l}\text { Severe } \\
\text { containment } \\
\text { conditions } \\
\text { after core } \\
\text { damage }\end{array}$ & $\begin{array}{l}\text { Severe } \\
\text { reactor } \\
\text { building } \\
\text { conditions } \\
\text { before core } \\
\text { damage }\end{array}$ & $\begin{array}{l}\text { Severe } \\
\text { reactor } \\
\text { building } \\
\text { conditions } \\
\text { after core } \\
\text { damage }\end{array}$ \\
\hline $\begin{array}{l}\text { Suppression pool water } \\
\text { temperature }\end{array}$ & $\mathrm{V} 1, \mathrm{~V} 2, \mathrm{C} 1, \mathrm{C} 2$ & $\bar{A}$ & & & & \\
\hline $\begin{array}{l}\text { Suppression pool water } \\
\text { level }\end{array}$ & $\mathrm{V} 1, \mathrm{C} 1$ & A & A & A & & \\
\hline Drywell pressure & $\begin{array}{l}\text { V1, V2, V4, } \\
\mathrm{C} 1, \mathrm{C} 2, \mathrm{C} 3, \mathrm{~F} 3\end{array}$ & $\bar{A}$ & A & A & & \\
\hline Drywell sump level & $\begin{array}{l}\mathrm{V} 2, \mathrm{~V} 3 \\
\mathrm{~V} 4, \mathrm{C} 3\end{array}$ & $\mathrm{~A}$ & & & & \\
\hline $\begin{array}{l}\text { Primary containment } \\
\text { isolation valve position } \\
\text { (drywell) }\end{array}$ & $\mathrm{C3}$ & $\bar{A}$ & & & & \\
\hline $\begin{array}{l}\text { Isolation valve position } \\
\text { (reactor building) }\end{array}$ & $\mathrm{C} 3$ & $\mathrm{~A}$ & $\bar{A}$ & A & & \\
\hline $\begin{array}{l}\text { Containment and } \\
\text { drywell oxygen } \\
\text { level }\end{array}$ & $\mathrm{V} 1, \mathrm{C} 1, \mathrm{C} 3$ & $\mathrm{~A}$ & $\bar{A}$ & $\bar{A}$ & & \\
\hline
\end{tabular}


Table 5. (continued).

\section{Category 1 (continued)}

\begin{tabular}{|c|c|c|c|c|c|c|}
\hline Plant instrumentation & $\begin{array}{l}\text { Safety } \\
\text { functions }\end{array}$ & $\begin{array}{c}\text { Severe } \\
\text { conditions only } \\
\text { in reactor } \\
\text { system }\end{array}$ & $\begin{array}{c}\text { Severe } \\
\text { containment } \\
\text { conditions } \\
\text { before core } \\
\text { damage }\end{array}$ & $\begin{array}{l}\text { Severe } \\
\text { containment } \\
\text { conditions } \\
\text { after core } \\
\text { damage }\end{array}$ & $\begin{array}{c}\text { Severe } \\
\text { reactor } \\
\text { building } \\
\text { conditions } \\
\text { before core } \\
\text { damage }\end{array}$ & $\begin{array}{c}\text { Severe } \\
\text { reactor } \\
\text { building } \\
\text { conditions } \\
\text { after core } \\
\text { damage }\end{array}$ \\
\hline $\begin{array}{l}\text { Containment and } \\
\text { drywell hydrogen } \\
\text { concentration }\end{array}$ & V3 & $\mathrm{A}$ & $\mathrm{A}$ & $\mathrm{A}$ & & \\
\hline $\begin{array}{l}\text { Containment area } \\
\text { radiation - high } \\
\text { range }\end{array}$ & $\begin{array}{l}\text { V1, V3, V4, } \\
\text { C1, C2, C3, F1, } \\
\text { F2, F3 }\end{array}$ & A & & & & \\
\hline $\begin{array}{l}\text { Main steam } \\
\text { isolation valve } \\
\text { position }\end{array}$ & $\mathrm{V} 1, \mathrm{~V} 4, \mathrm{C} 3$ & $\mathbf{A}$ & & & & \\
\hline
\end{tabular}


Table 5.

(continued).

Category 2

A Instrument Available

Degraded Performance Possible

\begin{tabular}{|c|c|c|c|c|c|c|}
\hline Plant instrumentation & $\begin{array}{l}\text { Safety }^{\mathrm{a}} \\
\text { functions }\end{array}$ & $\begin{array}{l}\text { Severe } \\
\text { conditions only } \\
\text { in reactor } \\
\text { system }\end{array}$ & $\begin{array}{c}\text { Severe } \\
\text { containment } \\
\text { conditions } \\
\text { before core } \\
\text { damage }\end{array}$ & $\begin{array}{l}\text { Severe } \\
\text { containment } \\
\text { conditions } \\
\text { after core } \\
\text { damage }\end{array}$ & $\begin{array}{l}\text { Severe reactor } \\
\text { building } \\
\text { conditions } \\
\text { before core } \\
\text { damage }\end{array}$ & $\begin{array}{l}\text { Severe } \\
\text { reactor } \\
\text { building } \\
\text { conditions } \\
\text { after core } \\
\text { damage }\end{array}$ \\
\hline $\begin{array}{l}\text { Standby liquid } \\
\text { control system flow } \\
\text { (pressure) }\end{array}$ & $\mathrm{V} 2$ & $\mathrm{~A}$ & A & A & & \\
\hline $\begin{array}{l}\text { Standby liquid } \\
\text { control system } \\
\text { storage tank level }\end{array}$ & $\mathrm{V} 2$ & $\mathrm{~A}$ & $\mathrm{~A}$ & $\mathrm{~A}$ & & \\
\hline $\begin{array}{l}\text { Primary system safety } \\
\text { relief valve position (or } \\
\text { flow) }\end{array}$ & $\mathrm{V} 1, \mathrm{~V} 2, \mathrm{C} 2, \mathrm{C} 3$ & A & & & & \\
\hline RCIC flow & $\mathrm{V} 1, \mathrm{~V} 4, \mathrm{C} 1$ & A & A & A & & \\
\hline HPCI flow & $\mathrm{V} 1, \mathrm{~V} 4, \mathrm{C} 1$ & A & A & A & & \\
\hline
\end{tabular}


Table 5. (continued)

\begin{tabular}{|c|c|c|c|c|c|c|}
\hline & & Category & (continued) & & & \\
\hline Plant instrumentation & $\begin{array}{l}\text { Safety } \\
\text { functions }\end{array}$ & $\begin{array}{l}\text { Severe } \\
\text { conditions only } \\
\text { in reactor } \\
\text { system }\end{array}$ & $\begin{array}{c}\text { Severe } \\
\text { containment } \\
\text { conditions } \\
\text { before core } \\
\text { damage }\end{array}$ & $\begin{array}{l}\text { Severe } \\
\text { containment } \\
\text { conditions } \\
\text { after core } \\
\text { damage }\end{array}$ & $\begin{array}{l}\text { Severe } \\
\text { reactor } \\
\text { building } \\
\text { conditions } \\
\text { before core } \\
\text { damage }\end{array}$ & $\begin{array}{l}\text { Severe } \\
\text { reactor } \\
\text { building } \\
\text { conditions } \\
\text { after core } \\
\text { damage }\end{array}$ \\
\hline Core spray flow & $\mathrm{V} 1, \mathrm{~V} 4$ & A & A & A & & \\
\hline LPCI flow & $\mathrm{V} 1, \mathrm{~V} 4, \mathrm{C} 2$ & A & A & A & & \\
\hline RHR system flow & $\mathrm{V} 1, \mathrm{C} 1$ & A & A & A & & \\
\hline RCIC room temperature & $\mathrm{V} 1, \mathrm{C} 1$ & A & A & A & & \\
\hline HPCI room temperature & $\mathrm{V} 1, \mathrm{C} 1$ & A & A & A & & \\
\hline $\begin{array}{l}\text { RHR heat exchanger } \\
\text { outlet temperature }\end{array}$ & $\mathrm{V} 1, \mathrm{C} 1$ & A & A & A & & \\
\hline
\end{tabular}


Table 5. (continued)

\begin{tabular}{|c|c|c|c|c|c|c|}
\hline \multicolumn{7}{|c|}{ Category 2 (continued) } \\
\hline $\begin{array}{l}\text { Drywell atmosphere } \\
\text { temperature }\end{array}$ & $\mathrm{V} 4, \mathrm{C} 1, \mathrm{C} 2$ & A & & & & \\
\hline Drywell spray flow rate & $\mathrm{V} 4, \mathrm{C} 1, \mathrm{C} 2$ & A & A & A & & \\
\hline $\begin{array}{l}\text { Emergency ventilation } \\
\text { damper position }\end{array}$ & $\mathrm{Cl}$ & $\mathrm{A}$ & $\mathbf{A}$ & $\mathbf{A}$ & & \\
\hline $\begin{array}{l}\text { Common plant vent or } \\
\text { multipurpose vent } \\
\text { release (unit vent) }\end{array}$ & $\mathrm{V} 1, \mathrm{~V} 4, \mathrm{C} 3, \mathrm{~F} 1$ & A & $\mathbf{A}$ & $\mathbf{A}$ & & \\
\hline
\end{tabular}


Table 5. (continued).

Category 2 (continued)

\begin{tabular}{|l|l|c|c|c|c|c|}
\hline & \multicolumn{1}{|c|}{$\begin{array}{c}\text { Safety } \\
\text { functions }\end{array}$} & $\begin{array}{c}\text { Severe } \\
\text { conditions only } \\
\text { in reactor } \\
\text { system }\end{array}$ & $\begin{array}{c}\text { Severe } \\
\text { containment } \\
\text { conditions } \\
\text { before core } \\
\text { damage }\end{array}$ & $\begin{array}{c}\text { Severe } \\
\text { containment } \\
\text { conditions } \\
\text { after core } \\
\text { damage }\end{array}$ & $\begin{array}{c}\text { Severe } \\
\text { reactor } \\
\text { building } \\
\text { building } \\
\text { conditions } \\
\text { before core } \\
\text { damage }\end{array}$ & $\begin{array}{c}\text { Sonditions } \\
\text { after core } \\
\text { damage }\end{array}$ \\
\hline $\begin{array}{l}\text { Common plant vent or } \\
\text { multipurpose vent } \\
\text { release (offgas) }\end{array}$ & V1, V4 & $\mathrm{A} 3, \mathrm{~F} 1$ & $\mathrm{~A}$ & $\mathrm{~A}$ & $\mathrm{~A}$ \\
\hline $\begin{array}{l}\text { Status of power } \\
\text { (electrical and other } \\
\text { energy sources) }\end{array}$ & $\mathrm{V} 1$ & $\mathrm{~A}$ & $\mathrm{~A}$ & $\mathrm{~A}$ & $\mathrm{~A}^{\mathrm{b}}$ & \\
\hline
\end{tabular}


Table 5. (continued).

\section{Category 3}

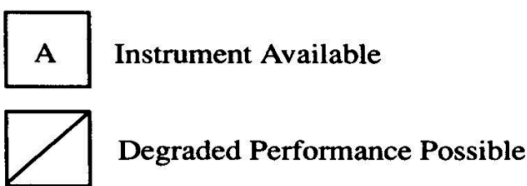

\begin{tabular}{|c|c|c|c|c|c|c|}
\hline Plant instrumentation & $\begin{array}{l}\text { Safety } \\
\text { functions }\end{array}$ & $\begin{array}{l}\text { Severe } \\
\text { conditions only } \\
\text { in reactor } \\
\text { system }\end{array}$ & $\begin{array}{c}\text { Severe } \\
\text { containment } \\
\text { conditions } \\
\text { before core } \\
\text { damage }\end{array}$ & $\begin{array}{l}\text { Severe } \\
\text { containment } \\
\text { conditions } \\
\text { after core } \\
\text { damage }\end{array}$ & $\begin{array}{c}\text { Severe } \\
\text { reactor } \\
\text { building } \\
\text { conditions } \\
\text { before core } \\
\text { damage }\end{array}$ & $\begin{array}{c}\text { Severe } \\
\text { reactor } \\
\text { building } \\
\text { conditions } \\
\text { after core } \\
\text { damage }\end{array}$ \\
\hline $\begin{array}{l}\text { Control rod } \\
\text { position indicator }\end{array}$ & V2 & $\overline{\mathrm{A}}$ & & & & \\
\hline $\begin{array}{l}\text { RCS soluble boron } \\
\text { concentration (grab } \\
\text { sample) }\end{array}$ & V2 & $\overline{\mathrm{A}}$ & $\bar{A}$ & $\overline{\mathrm{A}}$ & A & $\mathbf{A}$ \\
\hline $\begin{array}{l}\text { Main feedwater flow } \\
\text { rate }\end{array}$ & V1 & $\bar{A}$ & A & $\bar{A}$ & $\mathrm{~A}$ & $\mathbf{A}$ \\
\hline $\begin{array}{l}\text { Primary loop } \\
\text { recirculation flow }\end{array}$ & V1 & $\bar{A}$ & $\mathrm{~A}$ & $\bar{A}$ & & \\
\hline $\begin{array}{l}\text { Analysis of primary } \\
\text { coolant (gamma } \\
\text { spectrum) }\end{array}$ & V1, V3, V4, F1 & $\bar{A}$ & $\bar{A}$ & $\mathrm{~A}$ & $\mathrm{~A}$ & A \\
\hline
\end{tabular}


Table 5. (continued).

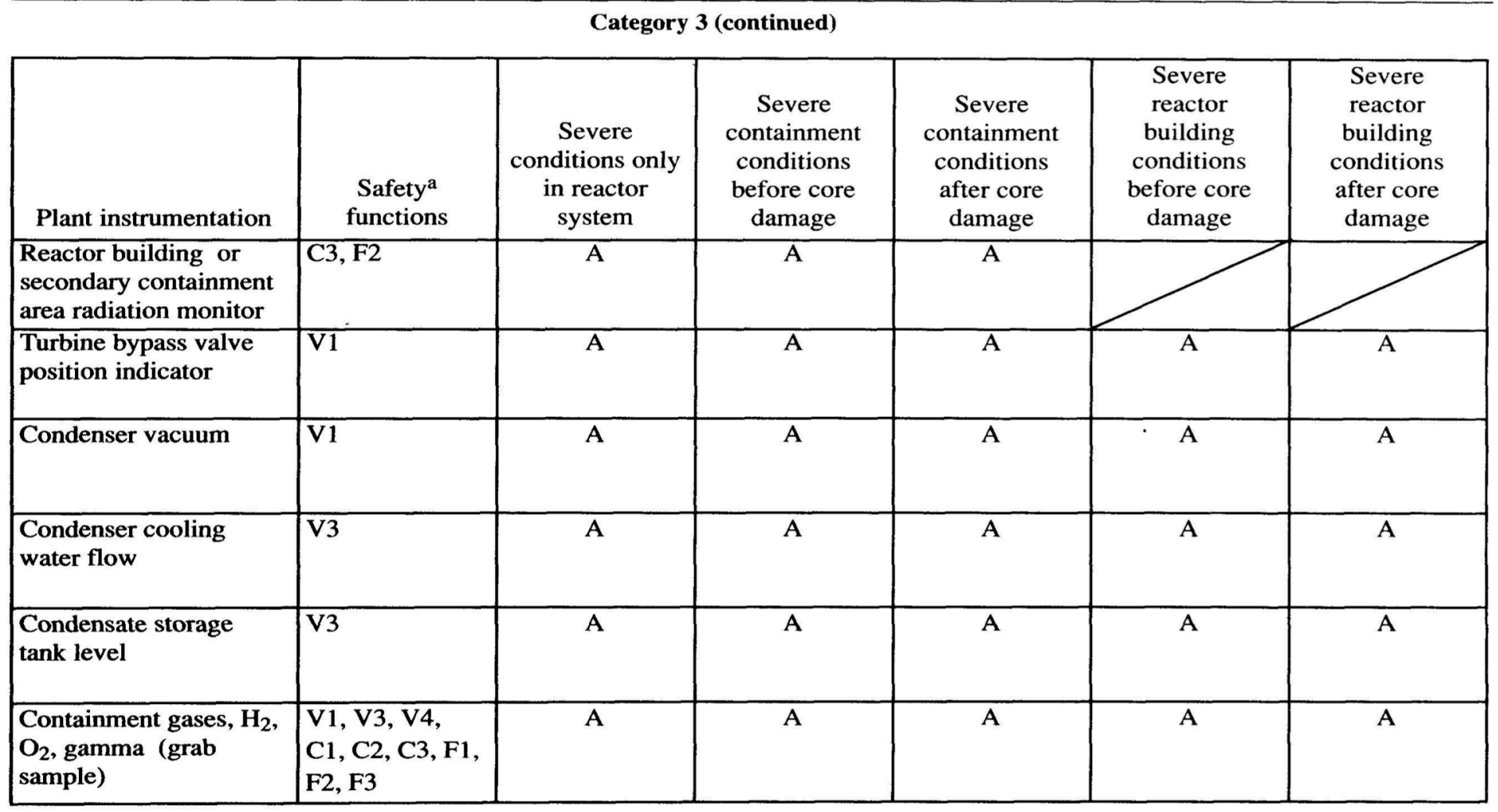


Table 5. (continued).

\begin{tabular}{|c|c|c|c|c|c|c|}
\hline \multicolumn{7}{|c|}{ Category 3 (continued) } \\
\hline Plant instrumentation & $\begin{array}{l}\text { Safety } \\
\text { functions }\end{array}$ & $\begin{array}{c}\text { Severe } \\
\text { conditions only } \\
\text { in reactor } \\
\text { system }\end{array}$ & $\begin{array}{c}\text { Severe } \\
\text { containment } \\
\text { conditions } \\
\text { before core } \\
\text { damage }\end{array}$ & $\begin{array}{l}\text { Severe } \\
\text { containment } \\
\text { conditions } \\
\text { after core } \\
\text { damage }\end{array}$ & $\begin{array}{l}\text { Severe } \\
\text { reactor } \\
\text { building } \\
\text { conditions } \\
\text { before core } \\
\text { damage }\end{array}$ & $\begin{array}{c}\text { Severe } \\
\text { reactor } \\
\text { building } \\
\text { conditions } \\
\text { after core } \\
\text { damage }\end{array}$ \\
\hline $\begin{array}{l}\text { Primary coolant } \\
\text { activity, boron, } \mathrm{H}_{2}, \mathrm{O}_{2} \text {, } \\
\text { (grab sample) }\end{array}$ & $\mathrm{V} 1, \mathrm{~V} 3, \mathrm{~V} 4, \mathrm{~F} 1$ & A & $\mathrm{A}$ & A & A & A \\
\hline
\end{tabular}

a. Abbreviations for safety function identification (from Figures 1, 2, and 3):

V1 Maintain Heat Sink

V2 Maintain Reactivity Control

V3 Maintain Core Heat Removal

V4 Maintain Vessel Boundary

C1 Maintain Pressure Control

C2 Maintain Temperature Control

C2 Maintain Temperature Control

C3. Maintain Integrity

F1 Control Fission Products in Primary Containment

F2 Control Fission Products in Secondary Containment

F3 Control Fission Products in Water

b. Portions of this system are located in the reactor building, turbine building, radwaste building, and diesel generator building. All systems would be available except those with components located in the reactor building, which could experience degraded performance. 
Table 6. Summary of Peach Bottom measurements not listed in Regulatory Guide 1.97.

A Instrument Available

7 Degraded Performance Possible

\begin{tabular}{|c|c|c|c|c|c|c|}
\hline Plant instrumentation & $\begin{array}{l}\text { Safety }{ }^{\mathrm{a}} \\
\text { functions }\end{array}$ & $\begin{array}{c}\text { Severe } \\
\text { conditions only } \\
\text { in reactor } \\
\text { system }\end{array}$ & $\begin{array}{c}\text { Severe } \\
\text { containment } \\
\text { conditions } \\
\text { before core } \\
\text { damage }\end{array}$ & $\begin{array}{c}\text { Severe } \\
\text { containment } \\
\text { conditions } \\
\text { after core } \\
\text { damage }\end{array}$ & $\begin{array}{c}\text { Severe } \\
\text { reactor } \\
\text { building } \\
\text { conditions } \\
\text { before core } \\
\text { damage }\end{array}$ & $\begin{array}{c}\text { Severe } \\
\text { reactor } \\
\text { building } \\
\text { conditions } \\
\text { after core } \\
\text { damage }\end{array}$ \\
\hline $\begin{array}{l}\text { Reactor building } \\
\text { pressure }\end{array}$ & $\mathrm{C} 3$ & $\mathrm{~A}^{\mathrm{b}}$ & $\mathrm{A}^{\mathrm{b}}$ & $\mathbf{A}^{\mathrm{b}}$ & & \\
\hline $\begin{array}{l}\text { Reactor building } \\
\text { temperature }\end{array}$ & C3 & $\mathrm{A}^{\mathrm{b}}$ & $\mathrm{A}^{\mathrm{b}}$ & $\mathrm{A}^{\mathrm{b}}$ & & \\
\hline
\end{tabular}

a. Abbreviations for safety function identification (from Figures 1, 2, and 3):

C3 Maintain Integrity

b. Qualification conditions not found in the available literature. 

APPENDIX C-OVERVIEW OF FUKUSHIMA UNITS 1-3 RESPONSE TO

EARTHQUAKE AND TSUNAMI

C-1 



\subsection{Fukushima Daiichi Unit 1 Response and Station Behavior}

\section{(1) Response Status Overview}

\section{(1) $15: 30$ to $16: 00$ on March 11}

Fukushima Daiichi Unit 1 was operating at rated electrical output, but went into automatic shutdown due to the Tohoku-Chihou-Taiheiyo-Oki Earthquake, which occurred at 14:46 on March 11. Off-site power was lost due to the earthquake, but the emergency diesel generator (EDG) automatically activated. Response operation toward cold shutdown was carried out at the MCR as per training. This included opening / closing the isolation condenser system (IC) valve to control reactor pressure.

A tsunami that easily covered the Reactor Building (R/B) and Turbine Building $(T / B)$ by several meters struck at 15:35, or approx. 50 minutes later. Both buildings were situated $10 \mathrm{~m}$ above sea level and large quantities of water flooded the buildings. Fortunately, the MCR, located on the second floor of the Service Building (S/B), was not flooded. However, the first floor of the S/B was flooded, meaning equipment and dosimeters needed to enter the controlled area were rendered unusable by seawater. Not only that, but entire racks were knocked down. Power from power source equipment within the building was entirely lost (both $A C$ and $D C$ ). This shut down motorized valves and pumps, as well as monitoring instruments. By this point, events had already veered far from the conditions foreseen in procedures determined in advance. The return of an operator, sopping wet, shouting "There's seawater rushing in!" made MCR operators certain that a tsunami had struck.

At this point, debris from the tsunami was scattered about the seaside area of the station, manhole covers had been washed away, and outdoor roads were sunken. It was in these dangerous conditions that building lighting was lost, leaving operators to grope through the darkness. Communication troubles meant no contact could be taken within the building (outside the MCR) or outside of it. Meanwhile, aftershocks kept striking and large tsunami alerts continued to stay in effect. Tsunamis of differing heights came relentlessly, meaning the risk of being swept away in a tsunami was far too great to leave the MCR on the second floor of the S/B and travel through the S/B $1 F$ to go outside.

\section{(2) $16: 00$ to $21: 00$ on March 11}

The site superintendent believed extremely difficult Severe Accident (SA) response would be required in the future, and ordered deliberation in accordance with procedures for cooling injection using the fire protection system (FP) line or fire engines. Station personnel began the necessary response amidst the harshest conditions both inside and outside the building. These included field surveys, power restoration, and road restoration.

In the MCR, reactor injection using the diesel-driven fire pump (DDFP) within the T/B which was still operable was considered. Under orders from the Shift Supervisor, field work at the T/B commenced. While workers tried to go to the R/B where the IC was located, their radiation measurement devices (used to detect contamination) gave higher 
readings than usual. Since the level of radiation was unknown and conditions were as abnormal as they come, the workers decided to turn back due to the necessity of reporting field conditions. Later, startup operation for the IC was performed in the MCR, as the display lamp for the IC was temporarily restored. Diagram confirmation was performed alongside this to deliberate vent procedures; since emergency lighting was insufficient, flashlights were used during this time.

Diagrams necessary for vents were also confirmed at the ERC at the power station, alongside various duties performed by the Recovery Team. These include monitoring instrument restoration work from the MCR, indoor/outdoor power source equipment soundness check for power restoration, confirmation of the location of fire engines, confirmation of the debris caused by the tsunami, restoration of roads to the station that were blocked, and debris removal.

After the loss of power, the ERC at the Headquarters ordered the ensuring of power supply cars and confirmation of their travel routes, and then began distribution.

\section{(3) $21: 00$ on March 11 to $02: 00$ on March 12}

Thanks to monitoring instrument restoration work by the Recovery Team at the ERC at the power station, station parameters such as reactor water level gradually became confirmable around 21:00 on March 11. The reactor water level displayed at this time was sufficient to cover fuel.

As for reactor injection via the DDFP, operators had ensured the reactor injection line, but high reactor pressure meant pressure on the DDFP side was insufficient for injection. Startup operation was performed while the temporarily restored IC display light became unstable.

The situation at that time still required caution. Meanwhile, indoor PCV vent inspection and road restoration work continued to take place. Power supply cars sent by Tohoku Electric arrived at the station around 22:00. Preparations for power restoration, such as temporary power cable collection, then began.

Work continued steadily, but station abnormality indicators were detected in succession. These were abnormal dose increase within the R/B and abnormal D/W pressure increase, both confirmed around 23:00. The DDFP stopped operating just before 02:00 on March 12.

While the shutdown of the DDFP meant the only remaining injection measure was fire engines, outdoor debris removal allowed said fire engines to come near the Unit 1 intake.

\section{(4) From 02:00 to $09: 00$ on March 12}

The search for an intake where the fire engine could be connected continued amidst the scattered debris from the tsunami. The fire engine was brought to the side of Unit 1 , connected to the intake discovered behind the T/B entryway, and fresh water injection via fire engine began at 04:00.

D/W pressure remained high, and PCV venting needed to be performed quickly. However, since radiation levels within the R/B were rising and lighting was poor, the focus in the MCR was on continued and specific confirmation of venting procedures to 
ensure the success of venting work in the field. At the same time, actions being taken at the ERC at the power station included confirmation of radiation levels within the R/B, work time evaluation, and confirmation of local resident evacuation status for venting of radioactive materials outside the station.

\section{(5) From 09:00 to $19: 00$ on March 12}

While reactor fresh water injection continued outside via fire engine, a team comprised of the Shift Supervisor and Shift Deputy Manager headed off into the field to perform venting work. This occurred around 09:00, when PCV venting preparations (e.g. evacuation status confirmation) were finally complete. Venting required two valves to be opened, and while one of them was open, the other was inaccessible because of the high dose in the area where it was set. Various efforts were attempted later in the MCR (e.g. flipping switch after connection to temporary power), but success of venting could not be confirmed. Therefore, an air condenser was brought from on-site and connected, allowing successful venting at 14:30.

The Site Superintendent knew fresh water would eventually run out during fresh water injection, and received the approval of the President to issue an order for seawater injection preparation to commence, around noon on March 12 . Immediately afterward, station workers began dispatching fire engines so as to transfer seawater stored in pits to Unit 1.

Power restoration that began on the evening of March 11 had progressed to where preparations were completed for the sending of power to the Unit 1 injection pump, and injection could soon commence.

Then the Unit $1 \mathrm{R} / \mathrm{B}$ exploded, damaging power cables and fire hoses at 15:36.

After the explosion, checks for injured and dosage were performed alongside fire hose repairs. Said repairs aimed toward swift restoration of injection, and took place in the dwindling light amidst debris scattered by the explosion. Seawater injection into the reactor began around 19:00. 


\subsection{Fukushima Daiichi Unit 2 Response and Station Behavior}

(1) Response Status Overview

(1) From around $15: 00$ to around $16: 00$ on March 11

Fukushima Daiichi Unit 2 was operating at rated thermal output, but shut down automatically due to the Tohoku-Chihou-Taiheiyo-Oki Earthquake which occurred at 14:46 on March 11. Off-site power was lost due to the earthquake, but the EDG automatically activated and response operation toward cold shutdown was performed as trained (e.g. ensuring reactor water level via $\mathrm{RCIC}$. However, tsunami arrival meant loss of power $(A C, D C)$ as with Unit 1, leading to equipment (e.g. motorized valve, motorized pump, monitoring instrument) inoperability. The accident already had become one greatly deviating from the conditions assumed in the procedure at this point.

Conditions both indoors and outdoors at this time were the same as those at Fukushima Daiichi Unit 1 (debris scattered outdoors, communication difficulties and no lights indoors).

(2) From around 16:00 on March 11 to around 15:30 on March 12

Reactor water level could not be confirmed and $\mathrm{RCIC}$ injection status was unclear due to loss of power. Therefore, the ERC at the power station recovery team performed MCR monitoring instrument restoration work and evaluated time when fuel exposure would occur if injection was not being performed. Alternate injection (FP) line assembly was also started in the MCR.

The ERC at the Headquarters ordered ensuring of power supply cars and access route checks due to loss of power, then began distribution.

Reactor water level was discovered to be TAF $+3,400 \mathrm{~mm}$ at 21:50. However, RClC operation status remained unknown, and the mood remained tense.

Operators were finally able to confirm, in total darkness, that the $\mathrm{RCIC}$ was operating at 02:55 on March 12. This eased the tension of personnel at Unit 2.

Since abnormal data continued to be discovered at Unit 1 between March 11 and March 12 , focus was placed solely on power restoration, injection into Unit 1 via fire engines, and PCV venting (details listed in Unit 1 response status).

(3) From around 15:30 on March 12 to around 11:00 on March 14

The Site Superintendent ordered deliberation toward vent line assembly at $17: 30$ on March 12. This was because it was predicted venting would become necessary at some time in the future, despite $\mathrm{D} / \mathrm{W}$ pressure stability. Based on this order, deliberations were performed at the ERC at the power station and MCR. PCV vent line assembly using temporary power was begun around 08:00 on March 13, and preparations completed at $11: 00$ on the same day.

Meanwhile, injection via RCIC continued operating despite loss of power meaning lack of control. If the $\mathrm{RCIC}$ were to shut down, then injection via fire engine after reactor 
depressurization would be the only means left until power restoration.

Injection switching at Unit 3 became neigh-impossible in the early hours of March 13, creating a highly tense atmosphere. Temporary power (batteries) required for Unit 3 reactor depressurization was collected, alongside batteries required for depressurization operation at Unit 2. These were brought to Units 1 and 2 MCR and connected to the control panel. This made Unit 2 depressurization possible at any time.

As for preparations for injection via fire engine, the in-house fire brigade distributed fire engines and installed hoses in accordance with orders from the Site Superintendent to begin seawater injection preparations. The fire engines were started up, meaning reactor injection via fire engine could be started at any time.

\section{(4) From around $11: 00$ to around 20:00 on March 14}

PCV venting line assembly and depressurization via battery power were completed. Also completed were preparations for injection via fire engine. It was then that the explosion at the Unit $3 \mathrm{R} / \mathrm{B}$ occurred at 11:01 on March 14. Due to debris scattering from the explosion, fire engines and injection lines were damaged and rendered unusable. The $\mathrm{AO}$ valve needed for venting also closed due to the explosion.

While the fear brought by the explosion remained fresh in their minds, personnel continued to dutifully proceed with injection line restoration. Due to a reactor water level drop, it was determined that $\mathrm{RCIC}$ lost function at $13: 25$ on the same day. Evaluation deemed TAF to have been reached at around 16:30.

Time was of the essence for injection restarting. Amidst frequent aftershocks with hypocenters offshore from Fukushima Prefecture, seawater injection preparations steadily advanced. Fire engines were finally activated and injection preparations completed around 15:30.

Although reactor depressurization preparations were completed, PCV venting preparations were carried out first due to PCV pressure and temperature conditions. Since it was determined that opening the valves needed for venting would take time, it was decided depressurization should take place first around 16:30, and the SRV was opened (depressurization operation). However, it refused to open, and connecting other SRV failed to improve things. After rewiring all ten batteries (12V), opening finally took place around 18:00.

Despite the time it took to depressurize the reactor, pressure levels dropped to those where injection via fire engine was possible. However, those fire engines were shut down due to lack of fuel. They were restarted and seawater injection commenced around 20:00.

\section{(5) From around 20:00 on March 14 to around 06:00 on March 15}

PCV (D/W, S/C) pressure did not decrease while CV venting line restoration proceeded. $\mathrm{S} / \mathrm{C}$ side line assembly was completed around 21:00 on March 14 . However, pressure levels at the time were not at prescribed levels where venting could be performed.

When monitoring PCV pressure, which normally would all have similar values, S/C 
pressure value remained stable despite $\mathrm{D} / \mathrm{W}$ pressure rising.

$\mathrm{D} / \mathrm{W}$ side venting line assembly was attempted, but failure led to emotions running high on site. It was then that a large impact noise and vibrations occurred around 6:14 on March 15 . At nearly the same time, the $\mathrm{S} / \mathrm{C}$ pressure display value showed downscaling, and was reported to be $0 \mathrm{kPa}$ to the $\mathrm{ERC}$ at the power station.

Since it was believed the $\mathrm{S} / \mathrm{C}$ was destroyed, all personnel barning the minimum number required to remain were evacuated.

Operators responsible for data monitoring gradually returned to Fukushima Daiichi NPS, and continued their restoration work. 
(1) Response Status Overview

(1) From around 15:00 on March 11 to around 12:00 on March 12

Fukushima Daiichi Unit 3 was operating at rated thermal output, but automatically shut down due to the Tohoku-Chihou-Taiheiyo-Oki Earthquake, which occurred at 14:46 on March 11. Off-site power was lost due to the earthquake, and the EDG automatically activated afterwards. Alongside this, response operations toward cold shutdown were carried out according to training. These included ensuring reactor water level via $\mathrm{RCIC}$. However, the EDG shut down and AC power was lost due to the tsunami. This led to a shutdown of valves, pumps, and monitoring instruments driven by $A C$ power. Although DC power loss occurred at Units 1 and 2, this was thankfully avoided at Unit 3.

This allowed flow rate to be adjusted via RCIC, since it ran off the DC power source. Cooling was able to be continued during this time while also saving battery power.

Indoor/outdoor conditions after tsunami arrival were the same as Fukushima Daiichi Unit 1 (debris scattered outdoors, lights off and communication difficulties indoors).

Since S/C pressure was on a rising trend, the MCR activated the FP DDFP and began $\mathrm{S} / \mathrm{C}$ spraying around $12: 00$ on March 12.

(2) From around 12:00 to around 20:30 on March 12

The RCIC used for cooling automatically shut down and reactor water level dropped around $11: 30$ on March 12 . However, the $\mathrm{HPCl}$ system automatically activated one hour later, and reactor water level began recovering. At the same time, reactor pressure began decreasing (reactor pressure dropped due to operation of the HCPI system, which had large capacity, as well as reactor steam release via pump drive turbine).

The awareness that DDFP injection would be taking over after $\mathrm{HPCl}$ system was shared at this time between the ERC at the power station and MCR.

Meanwhile, the Site Superintendent ordered PCV venting preparations. This was because it was assumed that PCV venting would be required some time in the future, even if PCV pressure was not that high. The ERC at the power station and MCR began procedure deliberations.

The inspection of power equipment usable at Units 3 and 4 began, and it was confirmed that the Unit 4 power panel was usable around 20:00 on March 12. Thus, restoration work using power supply cars was commenced.

Since the reactor water level indicator could no longer be monitored due to loss of power, it was during this time that ERC at the power station began instrument restoration work at 20:36. 
(3) From around 20:30 on March 12 to around 05:00 on March 13

Injection via $\mathrm{HPCl}$ system continued, DDFP was usable, and SRV was operable (its status display light was on). Thus, preparations for injection backup remained in place.

Reactor pressure remained low due to $\mathrm{HPCl}$ system operation. Reactor pressure showed signs of dropping further around $02: 00$ on March 13. Although automatic shutdown would normally occur at these pressure levels, this did not occur. Reactor injection via $\mathrm{HPCl}$ system also stopped. Therefore, work to switch reactor injection from $\mathrm{HPCl}$ system to DDFP commenced.

The MCR considered the switch to be complete at this time because DDFP line assembly changes from $\mathrm{S} / \mathrm{C}$ spray to reactor injection were being advanced in the field. The $\mathrm{HPCl}$ system was manually shut down at $02: 42$ on March 13 . In order to decrease reactor pressure, opening of the SRV (status display light was on) was attempted at 02:45. However, the SRV refused to open, and thus depressurization could not take place. Accordingly, injection via DDFP could not be started.

Operators immediately headed into the field to perform SRV restoration. They also attempted to restart the $\mathrm{RCIC}$ and $\mathrm{HPCl}$ system, but neither could be restored. Therefore, the Site Superintendent determined at 05:10 on March 13 that the situation (reactor cooling function loss) fell under Article 15 of the Nuclear Emergency Act.

\section{(4) From around 05:00 to around 09:00 on March 13}

Due to the necessity of swift reactor injection equipment restoration, restoration of power required to start up high pressure injection systems took place. However, it was discovered that the cables prepared in advance were damaged by the explosion at Unit 1 at $15: 36$ on March 12. Since power restoration would take time, the injection options available were limited to the DDFP and fire engines.

Injection via these options would require reactor depressurization. The ERC at the power station rushed to ensure temporary power (batteries) for the SRV. Ten batteries were gathered from cars and brought to the MCR. Here, they were connected to the control panel. This allowed the SRV to open around 09:00 on March 13. Thus did reactor depressurization begin, along with reactor fresh water injection via DDFP and fire engines prepared by that time.

It was during this time that the MCR and ERC at the power station began PCV venting line assembly under orders from the Site Superintendent. Line assembly was completed at $08: 41$ on March 13.

\section{(5) From around 09:00 on March 13 to around 15:30 on March 14}

D/W pressure drop was confirmed around 09:20 on March 13, and it was assumed that $\mathrm{PCV}$ venting had been implemented.

Response to keep the PCV vent valve open was carried out later (e.g., exchanging necessary air tanks).

Seawater injection was begun after switching water sources, since remaining fresh water was low. 